\title{
Polar forests on the edge of extinction: what does the fossil spore and pollen evidence from East Antarctica say?
}

\author{
E. M. Truswell ${ }^{\mathrm{A}, \mathrm{C}}$ and M. K. Macphail ${ }^{\mathrm{B}}$ \\ ${ }^{A}$ Research School of Earth Sciences, Australian National University, Canberra, ACT 0200, Australia. \\ ${ }^{B}$ Department of Archaeology and Natural History, Research School of Pacific and Asian Studies, \\ Australian National University, Canberra, ACT 0200, Australia. \\ ${ }^{\mathrm{C} C}$ Corresponding author. Email: etruswell@aapt.net.au
}

\begin{abstract}
Diverse pollen and spore assemblages, spanning the Late Eocene preglacial-glacial transition, have been recovered from Ocean Drilling Program cores from Prydz Bay, East Antarctica. These microfloras are mostly in situ and provide an unparalleled record of terrestrial plant communities growing in Antarctica during the earliest stages of ice-cap formation. The evidence provides a basis for assessing the phytogeographic relationships of the Antarctic floras with other high-latitude floras in the southern hemisphere, including possible migration routes for some taxa. Preliminary studies (Macphail and Truswell 2004a) suggested the Late Eocene vegetation at Prydz Bay was floristically impoverished rainforest scrub, similar to Nothofagus-gymnosperm communities found near the climatic treeline in Patagonia and Tasmania. Re-evaluation of the microfloras indicates the diversity of shrubs, especially Proteaceae, was underestimated and the Late Eocene vegetation was a mosaic of dwarfed (krumholtz) trees, scleromorphic shrubs and wetland herbs, analogous to the taiga found in the transition zone between the boreal conifer forest and tundra biomes across the Arctic Circle. Microfloras similar to although much less diverse than the Prydz Bay assemblages occur in coreholes from the Ross Sea region on the opposite side of Antarctica. Interpretation of the latter is complicated by reworking and low yields but the combined evidence points to the collapse of taller woody ecosystems during the Eocene-Oligocene transition and their replacement by tundra-like or fell-field vegetation during the Oligocene and Neogene. This temperature-forced regression seems to have been broadly synchronous across the continent. The high-palaeolatitude location $\left(\sim 70^{\circ} \mathrm{S}\right)$ means that the Prydz Bay flora was adapted to several months of winter darkness and short-summer growing seasons. The nearest living relatives of identifiable woody taxa suggest year-round high humidity, with an annual precipitation between $\sim 1200$ and 1500 mm. Palaeotemperatures are more difficult to quantify although the inferred humid microtherm climate is consistent with mean annual temperatures less than $12^{\circ} \mathrm{C}$ and freezing winters.
\end{abstract}

\section{Introduction}

Antarctica is unique in that it is the only continent where Cenozoic glaciation has forced the extinction of all woody plant life sometime during the middle to late Neogene. In terms of individual species, this 'extinction event' was not particularly rapid because a minimum of 20 shrubs or low trees appears to have survived the expansion of the East Antarctic ice sheet down to sea level during the Oligocene and possibly seven or eight low shrubs may have survived in the fell-field communities on the Transantarctic Mountains as recently as the Pliocene, assuming the macrofloras are correctly dated (references in Francis and Hill 1996; Askin and Raine 2000; DeConto and Pollard 2003; Ashworth and Cantrill 2004; Prebble et al. 2006). At least one family (Chenopodiaceae) may have become established in East Antarctica during the Oligocene (see Raine and Askin 2001). Nevertheless, the taiga-like vegetation which grew in Prydz Bay - the Late Eocene successor of the preglacial forests and woodlands named Austral Conifer Forest by Macphail and Truswell (2004a) and, more dramatically, Ice Forests by the producers of the 1990s BBC series Walking with Dinosaurs - almost certainly had collapsed as a viable ecosystem some 18-29 million years earlier, during the Eocene-Oligocene transition period.

This conclusion has been largely based on a comparison of fossil spores and pollen assemblages (microfloras) preserved in the Ross Sea region. There, Middle to Late Eocene erratics in the McMurdo Sound area preserve a record of species forming the preglacial polar scrub communities whereas microfloras recovered from glacimarine sequences in the Ross Sea and adjoining continental shelf in East Antarctica preserve a record of species forming tundra-like communities following glaciation of East Antarctica during the Oligo-Miocene (cf. Raine 1998; Askin 2000; Raine and Askin 2001; Prebble et al. 2006; Warny et al. 2006). However, low to very low yields, and probable reworking and mixing of palynomorphs because of glacial erosion and cryoturbation, makes it difficult to determine which fossil spores and pollen (miospores) are in situ.

In the present paper, we illustrate and discuss well preserved fossil miospores recovered from the only Middle to 
Late Eocene sediments found so far in East Antarctica that are clearly in place. The sedimentary sequence spans the preglacialglacial interval in Prydz Bay (Fig. 1), and was drilled by the Ocean Drilling Program (ODP) in 2000. Microfloras recovered from the sequence provide an unparalleled record of woody taxa growing in East Antarctica during the final tenure of the Ice
Forests in East Antarctica. Although, inevitably, the pollen and spore assemblages contain some elements that may be recycled from older sequences, we contend that they provide an improved basis for assessing the relationship of the Middle and Late Eocene floras to other fossil and extant floras growing at high latitudes or altitudes in the southern hemisphere. Relative-

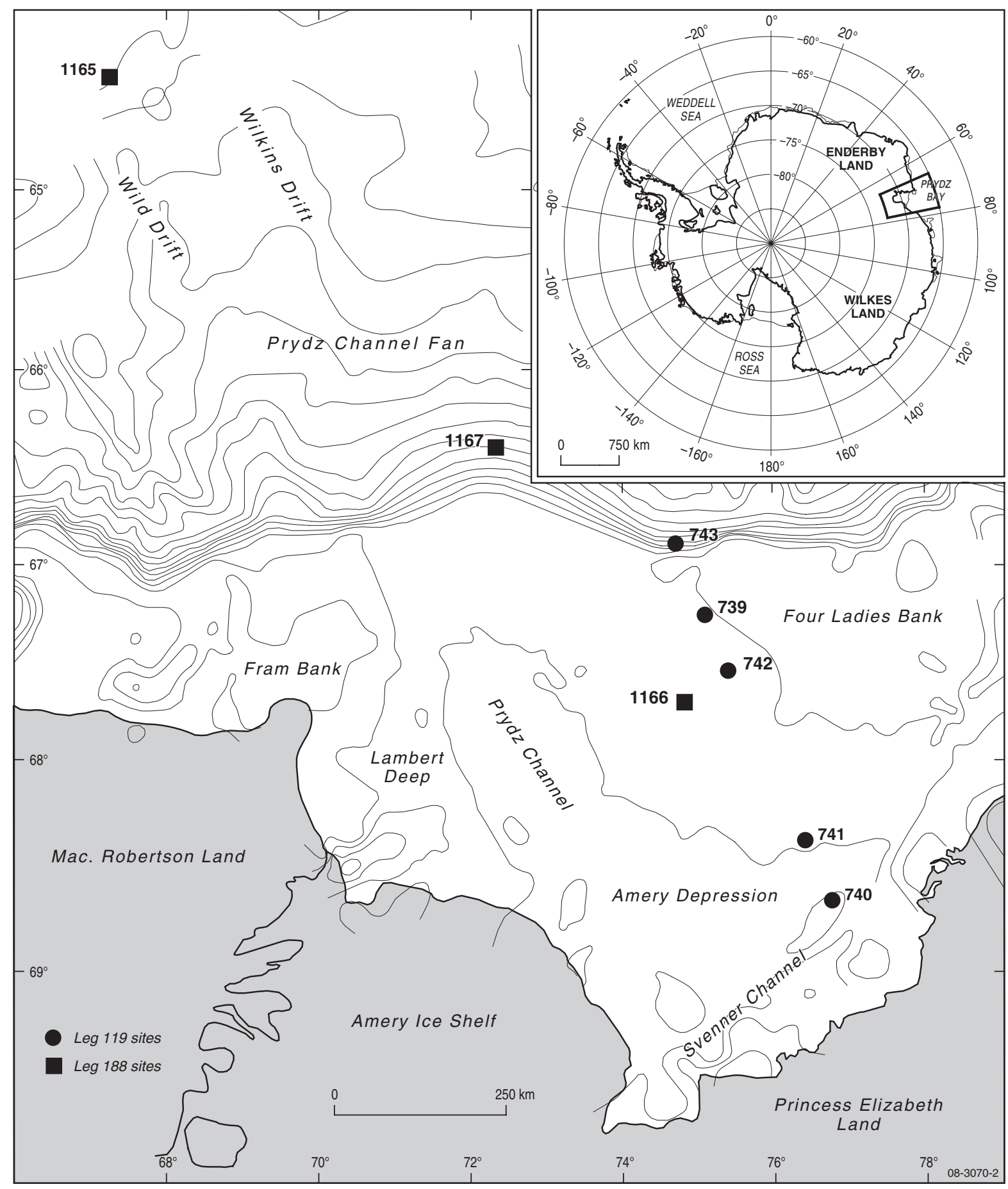

Fig. 1. Locality map of Prydz Bay, East Antarctica, showing Site 1166 in the central depression. Sites 1165-1167 were drilled during Leg 188 of the Ocean Drilling Program; Sites 739-742 were drilled during Leg 119 in 1991 (see Truswell 1991). 
abundance data, expressed as a percentage of the terrestrial count (Table 1), suggest that species present in the Late Eocene formed a mosaic of krumholtz rainforest trees, scleromorphic shrubs and wetland herbs, analogous in structure to communities now found in the Arctic region of the northern hemisphere, although dominated by species whose nearest living relatives (NLRs) are found in temperate rainforest and rainforest scrub in the southern hemisphere. The closest structural analogue appears to be the taiga communities found in the transition zone between the boreal conifer forests and tundra biomes in Scandinavia, Russia and northern North America.

\section{Geological setting}

Prydz Bay forms a prominent re-entrant in the coastline of East Antarctica between $66^{\circ}$ and $79^{\circ} \mathrm{E}$, in the sector of the continent that faces the Indian Ocean (Fig. 1). The bay is situated at the downstream end of the Lambert Glacier-Amery Ice Shelf drainage basin. This ice stream is the largest system flowing from the interior and drains some $20 \%$ of East Antarctica. The drainage basin is controlled by the bedrock Lambert Graben, a deep crustal structure extending $600 \mathrm{~km}$ inland. The ice-source region includes the Gambertsev Mountains, an elevated area that, according to some models, may have formed the loci for the first Palaeogene glaciers. It is likely that sediment would have been delivered into Prydz Bay from the inception of continental glaciation, as well as during subsequent phases of ice expansion. This offshore region is thus an ideal place to document the glacial history of the drainage basin and the terrestrial vegetation growing within it.

The material that forms the basis of the present study comes from ODP Site 1166 in Prydz Bay, drilled during Leg 188 of the Ocean Drilling Program. A review of the aims and results of this cruise leg is provided by O'Brien et al. (2001) and by Cooper and O'Brien (2004), and summarised by Whitehead et al. (2006). A primary aim of this cruise was to date the earliest evidence of glacial activity in the region, and to delineate the Palaeogene environment of Antarctica by drilling on the continental shelf.

Three sites were drilled in the Prydz Bay region during Leg 188 (Fig. 1). Sites 1165 and 1167 were drilled on the continental rise and slope offshore and these coreholes sampled thick, mainly glacial sediments extending back to the Early Miocene. The very low numbers of palynomorphs recovered from these cores include recycled taxa as well as

Table 1. Relative abundance of selected, commonly occurring taxa, 142.5-220.85 m below the modern sea floor (mbsf)

Values calculated as a percentage of the total spore-pollen count, excluding recycled species. + , values less than $1 \%$. Statistically unreliable values are given in parentheses

\begin{tabular}{|c|c|c|c|c|c|c|c|c|c|}
\hline \multirow[t]{2}{*}{ Fossil taxon } & \multirow[t]{2}{*}{ Nearest living relative } & \multicolumn{8}{|c|}{ Depth (mbsf) } \\
\hline & & 142.5 & 148.36 & 156.99 & 170.98 & 180.4 & 200.67 & 210.18 & 220.85 \\
\hline \multicolumn{10}{|l|}{ Cryptogams } \\
\hline Baculatisporites spp. & Hymenophyllaceae? & $(2 \%)$ & & $2 \%$ & + & & $(4 \%)$ & + & + \\
\hline Cyathidites minor-australis & Cyatheaceae & $(2 \%)$ & & $2 \%$ & $1 \%$ & & & $1 \%$ & $1 \%$ \\
\hline Gleicheniidites spp. & Gleicheniaceae & & & + & + & + & & + & + \\
\hline Laevigatosporites ovatus-major & Blechnaceae & & & + & $1 \%$ & $4 \%$ & & $2 \%$ & + \\
\hline Retitriletes spp. & Lycopodiaceae & $(2 \%)$ & + & + & + & & & + & + \\
\hline Total cryptogams & & $(9 \%)$ & $(2 \%)$ & $7 \%$ & $4 \%$ & $7 \%$ & $(4 \%)$ & $7 \%$ & $4 \%$ \\
\hline \multicolumn{10}{|l|}{ Gymnosperms } \\
\hline Araucariacites australis & Araucaria & & $(2 \%)$ & $5 \%$ & $3 \%$ & $4 \%$ & $(4 \%)$ & $4 \%$ & $9 \%$ \\
\hline Cupressacites & Cupressaceae & & $(2 \%)$ & + & $1 \%$ & $1 \%$ & & + & $2 \%$ \\
\hline Dacrycarpites australiensis & Dacrycarpus & & & & & + & & + & \\
\hline Dilwynites granulatus & Agathis/Wollemia & & & + & $1 \%$ & $1 \%$ & $(4 \%)$ & + & $2 \%$ \\
\hline Lygistepollenites florinii & Dacrydium & & $(4 \%)$ & & $2 \%$ & + & & + & $1 \%$ \\
\hline Microcachryidites antarcticus & Microcachrys & & $(2 \%)$ & + & + & $2 \%$ & & $1 \%$ & + \\
\hline Phyllocladidites mawsonii & Lagarostrobos & $(2 \%)$ & $(6 \%)$ & + & $3 \%$ & + & $(8 \%)$ & $3 \%$ & $2 \%$ \\
\hline Podocarpidites spp. & Podocarpus & $(20 \%)$ & $(22 \%)$ & $15 \%$ & $15 \%$ & $18 \%$ & $(16 \%)$ & $16 \%$ & $14 \%$ \\
\hline $\begin{array}{l}\text { Trichotomosulcites subgranulosus } \\
\text { complex }\end{array}$ & Microcachrys & $(13 \%)$ & $(7 \%)$ & $3 \%$ & $4 \%$ & + & $(4 \%)$ & $5 \%$ & $4 \%$ \\
\hline Total gymnosperms & & $34 \%$ & $(44 \%)$ & $26 \%$ & $29 \%$ & $31 \%$ & $(40 \%)$ & $31 \%$ & $35 \%$ \\
\hline \multicolumn{10}{|l|}{ Angiosperms } \\
\hline Malvacipollis spp. & Euphorbiaceae & & & + & $1 \%$ & & & & \\
\hline Nothofagidites asperus complex & Nothofagus (Lophozonia) & $(2 \%)$ & $(6 \%)$ & $5 \%$ & $10 \%$ & $4 \%$ & $(4 \%)$ & $8 \%$ & $9 \%$ \\
\hline Nothofagidites brachyspinulosus complex & Nothofagus (Fuscospora) & $(2 \%)$ & $(4 \%)$ & $12 \%$ & $8 \%$ & $19 \%$ & $16 \%$ & $22 \%$ & $13 \%$ \\
\hline Nothofagidites flemingii complex & Nothofagus (Nothofagus) & $(11 \%)$ & $(6 \%)$ & $9 \%$ & $10 \%$ & $12 \%$ & $(12 \%)$ & $6 \%$ & + \\
\hline Nothofagidites goniatus & Nothofagus (Lophozonia) & $(2 \%)$ & & + & $1 \%$ & $3 \%$ & & $3 \%$ & $3 \%$ \\
\hline Nothofagidites lachlaniae complex & Nothofagus (Fuscospora) & $(38 \%)$ & $(31 \%)$ & $35 \%$ & $31 \%$ & $20 \%$ & $(20 \%)$ & $18 \%$ & $28 \%$ \\
\hline Proteacidites spp. & Proteaceae & $(2 \%)$ & & $2 \%$ & $3 \%$ & $2 \%$ & & $2 \%$ & $2 \%$ \\
\hline Rhoipites/Tricolporites spp. & Numerous families & & $(2 \%)$ & $1 \%$ & $2 \%$ & $1 \%$ & $(4 \%)$ & $2 \%$ & $3 \%$ \\
\hline Total angiosperms & & $(56 \%)$ & $(54 \%)$ & $67 \%$ & $66 \%$ & $62 \%$ & $(60 \%)$ & $62 \%$ & $61 \%$ \\
\hline Recycled taxa & & $(15 \%)$ & $(6 \%)$ & $3 \%$ & $11 \%$ & $5 \%$ & $(32 \%)$ & $4 \%$ & $5 \%$ \\
\hline Pollen sum & & 55 & 54 & 275 & 312 & 244 & 25 & 248 & 287 \\
\hline
\end{tabular}


taxa likely to be in situ (cf. Raine and Askin 2001; Macphail and Truswell 2004b; Hannah 2006; Warny et al. 2006). Site 1166 , on which the present study is based, was drilled on the continental shelf, in a water depth of $486 \mathrm{~m}$ on the southwestern flank of a bathymetric feature known as the Four Ladies Bank. It aimed to sample the earliest Cenozoic glacial sediment, in order to date the onset of glaciation in East Antarctica and document associated environmental changes.

Five lithologic units were identified in the sequence penetrated at Site 1166 (O'Brien et al. 2001; Cooper and O'Brien 2004; Fig. 2). The shallowest of these, Unit I, from the modern seafloor down to $135.41 \mathrm{~m}$ below the modern sea floor (mbsf), is essentially glacial in nature, with diamictons and diatom-bearing silts. Unit II (135.63-156.62 mbsf) is composed of diatom-bearing claystones, with thin interbedded silts. Unit III (156.62-267.17 mbsf), which consists of massive and deformed sands with a silty clay matrix in its lower parts, is rich in organic matter and includes pieces of wood. This unit probably represents glacial outwash sands deposited on an alluvial plain or delta (Whitehead et al. 2006). The Late Eocene material analysed in the present study comes from Units II and III. Unit IV (276.44-314.91 mbsf) consists of carbonaceous clays and silts with organic-rich laminae. It was probably deposited in a lagoon or similarly restricted marine environment. Unit V, which was poorly sampled, is a finely laminated grey claystone. These lower units are Late Cretaceous (Turonian to? Santonian) and are separated from the Eocene sequences by an unconformity surface of low relief. A rafted clast of Turonian to? Santonian age occurs at $249.36 \mathrm{mbsf}$ within Unit III. The interval as a whole is inferred to be part of one or more transgressive systems tracts in which preglacial marginal marine conditions were replaced by a shallow open marine environment.

During the period represented by Units II and III, the East Antarctic ice sheet extended from the mountain front down to sea level and onto the continental shelf. Unit II contains dropstones or lonestones signalling the arrival of glaciers at sea level in Prydz Bay; Unit III has the highest frequency of sand grains, with features that develop only in a subglacial environment, suggesting the deposits were sourced at least in part by a glacier (see Strand et al. 2003). Given the alluvial plain or delta environment of Unit III, it is possible that a component of the terrestrially derived miospores derives from plants growing in, or lining, tidal channels within the Prydz Bay delta; however, all assemblages include some miospores eroded from Mesozoic and Palaeozoic rocks and may include miospores transported by melt-water from vegetation growing on the Prince Charles Mountains within the Lambert Glacier drainage basin. Potential sources for the recycling of Mesozoic and Palaeozoic spores and pollen are known within the general region. For example, fossiliferous Jurassic and Cretaceous sediments occur beneath the Mac.Robertson Shelf, immediately west of Prydz Bay (Truswell et al. 1999), and Permian and Triassic assemblages have been described from the Amery Group within the Lambert Glacier drainage basin (Foster et al. 1994).

\section{Age control}

The proposed Late Eocene age of sediments between 142.5 and $240.36 \mathrm{mbsf}$ at Site 1166 is primarily based on marine dinocyst and acritarch species (see discussion in Macphail and Truswell 2004a). Most of these belong to the distinctive and long-ranging (Middle-Late Eocene) 'Transantarctic Flora', which was first identified in erratic boulders from McMurdo Sound (Wilson 1967; Wrenn and Hart 1988). The distribution of this high-latitude assemblage has been reviewed by Truswell (1997) and Levy and Harwood (2000); however, the broad Middle to Late Eocene age remains imprecise because of its limited diversity, and the fact that the sequences in which it occurs are often thin and lack independent age control. A narrower Late Eocene age for samples between 142.5 and $220.85 \mathrm{mbsf}$ is suggested by the presence of two dinocyst species, Paucilobimorpha (al. Tritonites) spinosus (Fig. 238) and Corrudinium sp. cf. C. incompositum, which are generally restricted to Late Eocene marine sediments in the continental margin basins of southern Australi, such as the Gippsland Basin (Marshall and Partridge 1988; Truswell 1997; Partridge 1999). The absence of one of the diagnostic species of the 'Transantarctic Flora', Arachnodinium antarcticum, provides circumstantial support for the Late Eocene age of the Prydz Bay sequence, because this dinocyst is most abundant in the Middle Eocene (Foraminiferal Zones P8-10).

\section{Taxonomic constraints}

Assigning many of the fossil pollen and spores recovered between 142.5 and $240.36 \mathrm{mbsf}$ at Site 1166 to formally described fossil species is difficult for four reasons. (1) The majority of previously described fossil (form) species represent populations that may have been geographically separated from their relatives at Prydz Bay for long periods of geologic time, up to 30 million years in the case of New Zealand and arguably even longer in the case of some species described from South America. As emphasised by Macphail and Cantrill (2006) in their analysis of Mio-Pliocene assemblages from the Falkland Islands, many form species have been widely identified throughout the Austro-Pacific regions and the resultant broadening of taxonomic concepts has meant that many morphotypes bear only limited resemblance to the designated holotypes of the fossil species. (2) Morphotypes treated as distinct species in one region sometimes fall within the morphological span of different fossil species elsewhere. (3) Many of the commonly occurring species are linked by a continuum of intermediate morphotypes. (4) Most of the rare taxa are represented by one to several pollen grains or spores only. For these reasons, we consider it premature to erect new species and have followed the approach adopted by Macphail and Truswell (2004a) in regarding many of the

Fig. 2. Stratigraphic sequence in Hole 1166A, showing cored intervals, lithology and biostratigraphic zones (from Cooper and O’Brien 2004). Zones shown in the 'Palynology' column are those of the Gippsland Basin in south-eastern Australia (Stover and Partridge 1973). 


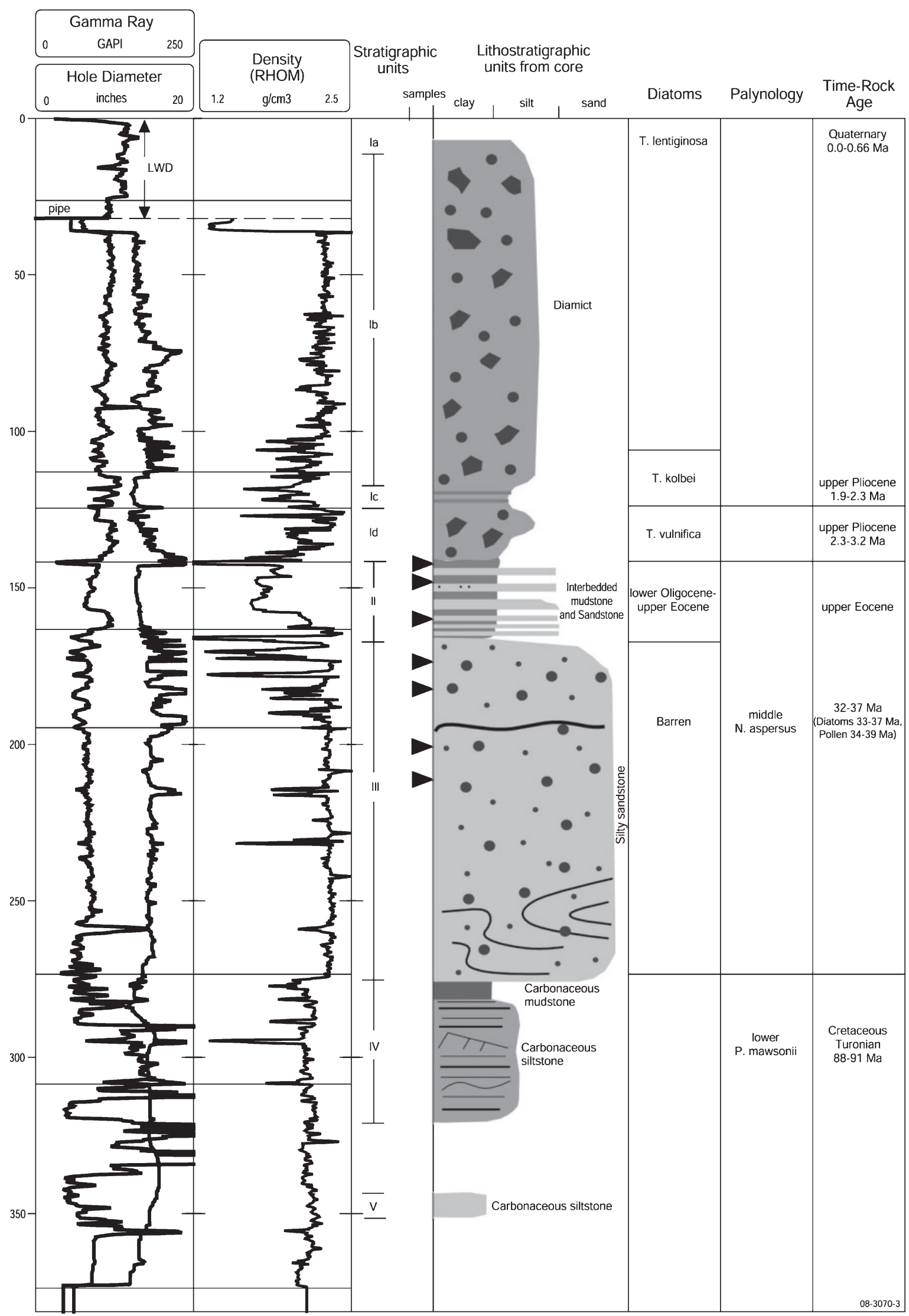


morphotypes present at Prydz Bay as members of species complexes. For example, gymnosperm pollen types resembling Podosporites parvus, $P$. microsaccatus or Trichotomosuculcites subgranulatus are treated as members of the same Podosporites-Trichotomosuculcites complex; similarly, angiosperm pollen types resembling Nothofagidites asperus, $N$. americanus or $N$. teheulchesii are considered to be members of the same (Nothofagidites asperus) complex. Revision of palynosequences recovered from offshore basins in south-western Western Australia (M. K. Macphail, unpubl. data) indicated that some of the Prydz Bay spore and gymnosperm morphotypes assigned to Tertiary morphospecies by Macphail and Truswell (2004a) may be reworked Mesozoic species. For example, Herkosporites elliottii and large specimens of Microcachryidites antarcticus characterised by coarsely regulate cappa are now considered to be Neoraistrickia sp. cf. $N$. suratensis and Trisaccites (al. Podosporites) variabilis, respectively.

Although the focus of the present paper is on the botanical affinities of the fossil pollen and spores types, we recognise these miospores represent plants that were growing at Prydz Bay some 34-37 million years ago. We are therefore cognisant of evolutionary changes that are likely to have occurred since then. Because few, if any, of the NLRs of the Prydz flora produce pollen or spores that are distinctive at the species level, we propose that the many of the more distinctive morphotypes illustrated in the present paper are likely to represent extinct genera, and more rarely, extinct plant families or even higher taxonomic rankings.

\section{Prydz Bay palaeoflora}

All major dryland plant groups are represented in the Late Eocene microfloras and many form species can be assigned to living families of ferns and fern allies (cryptogams), conifers and angiosperms (Tables 1,2). Whether the parent plants were woody is less clear since many 'woody' angiosperm families also include some herbaceous genera, and some ferns attain the stature of small trees. In several instances, we have had to refer the Prydz Bay spores and gymnosperm pollen to morphospecies that became extinct in southern Australia during the Mesozoic or Early Tertiary, although it is not definite that these taxa are recycled at Prydz Bay. Examples are (NLRs in parentheses) Ruffordiaspora (al. Cicatricosisporites) australiensis (cf. Anaemia) and Lygistepollenites balmei (Dacrydium). Conversely, we presume that angiosperm pollen types that last occur in the Late Cretaceous and Early Paleocene in south-eastern Australia are probably reworked. This may or may not be the case for angiosperm pollen types which occur into the Late Paleocene and Early-Middle Eocene because of the possibility that perennially cool-cold climates allowed the parent plants to survive in East Antarctica long after their relatives became extinct in southern Australia. Examples in the first category are Battenipollis sectilis, Forcipites sabulosus, Tricolpites confessus and Tetracolporites verrucosus; examples in the second category are Australopollis obscurus, Gambierina spp. and Triprojectacites spp. cf. Integricorpus. In some instances, it has not been possible to illustrate rare species because of poor preservation or orientation of the specimen(s). Fossil wood confirms the presence of at least two families (Poole et al. 2003) on the Antarctic Peninsula and Shetland Islands that may have been present in East Antarctica; however, pollen of these families will be difficult to detect owing to their very small size (Eucryphiaceae), and thus may be lost during preparation, or very low pollen production (Lauraceae).

\section{Chlorophyta}

Cysts of probable fresh- to brackish-water algae occur in most samples although only one morphotype can be assigned to a living family.

Botryococcus sp. cf. B. braunii Kutzing 1849 (Fig. 3). Roughly sphaeroidal colonies of the green alga Botryococcus occur in low numbers throughout the sequence. Modern Botryococcus is widely distributed in fresh-water bogs and fresh- to brackish-water ponds and lakes in temperate to tropical regions, and is known to be tolerant of seasonally cold conditions (Batten and Grenfell 1996). The Prydz Bay records indicate the colonial alga was able to survive prolonged winter darkness as well as seasonal freezing.

\section{Bryopsida}

Spores assigned with varying degrees of confidence to two bryophyte (moss) families occur in trace numbers throughout the interval. The rarity of bryophytes is difficult to explain because mosses are widespread in cool-cold environments at present and ancestral forms of peat moss (Sphagnum) were abundant in winter-dark and seasonally very cold environments in central and southern Australia throughout the Aptian-Albian (Burger 1988, 1990).

\section{Bartramiaceae?}

Coptospora archangelskyi Zamaloa 2004 (Figs 4-7). Rare specimens of this species occur in the Late Eocene interval at Site 1166 and closely resemble $C$. archangelskyi, except that the ornamentation consists of elongate rather than circular verrucae (cf. fig. $3 d-f$ in Zamaloa 2004). The species is more consistently recorded in the Oligo-Miocene glacio-marine sequences from Ross Sea (Prebble et al. 2006; Warny et al. 2006) and also at ODP Sites 1165 and 1167 (Macphail and Truswell 2004b) than at Site 1166. Recycled specimens from the Ross Sea that Truswell (1983, plate 2, figs 4, 5) compared with Coptospora sp. A of Dettmann (1963), are the same species. Raine (1998) referred the species to the Bartramiaceae, on the basis of the verrucate ornamentation and interpretation of the aperture as a hilum (defined as a circular indistinctly defined laesura by Erdtman (1952)). Macphail and Truswell (2004b) challenged this interpretation, noting that the hilum in the Prydz Bay specimens has a distinct margin and the ornamentation of smooth, regular verrucae is more typical of the fossil genus Polypodiisporites and spores produced by living species within the Davalliaceae (e.g. Davallia) and Polypodiaceae (e.g. Microsorium). The affinity remains unresolved, although it is noted that one well orientated specimen from 87.47 to $87.49 \mathrm{mbsf}$ in Cape Roberts Drillhole CRP-3 is hilate and closely resembles the Mesozoic 
Table 2. Stratigraphic distribution of miospore taxa

mbsf, metres below the modern sea floor; cf, specimens comparable with, but not identical to, the named species that have been found there

\begin{tabular}{|c|c|c|c|c|c|c|c|c|c|}
\hline \multirow[t]{2}{*}{ Fossil taxon } & \multirow[t]{2}{*}{ Nearest living relative } & \multicolumn{8}{|c|}{ Depth (mbsf) } \\
\hline & & 142.50 & 148.36 & 156.99 & 170.98 & 180.40 & 200.67 & 210.18 & 220.85 \\
\hline \multicolumn{10}{|l|}{ Cryptogams } \\
\hline $\begin{array}{l}\text { Appendicisporites } \text { sp. cf. } \\
\text { A. crassicarinatus }\end{array}$ & Schizaeaceae (Anaemia) & & & $\mathrm{cf}$ & & + & & & \\
\hline Baculatisporites comaumensis & Hymenophyllaceae? & & + & + & & & + & & + \\
\hline cf. Belgisporis & Unknown & & + & & & & & & \\
\hline Botryococcus & Botryococcus & + & + & & & & & & \\
\hline Clavifera triplex & Gleicheniaceae & & & + & & + & & & \\
\hline Coptospora archangelskyi & Hepaticae? & + & + & & & & & & \\
\hline Cyathidites minor-australis & Cyatheaceae & + & + & + & + & + & & + & + \\
\hline Dictyophyllidites cf. arcuatus & Gleicheniaceae & + & & + & & & & & \\
\hline Foveosporites sp. cf. F. canalis & Lycopodiaceae & & & + & & & & & \\
\hline Gleicheniidites spp. & Gleicheniaceae & & + & + & & + & & + & \\
\hline Laevigatosporites ovatus-major & Blechnaceae & + & & & + & + & & + & + \\
\hline Leptolepidites cf. verrucatus & Unknown & & & + & & & & & \\
\hline Monolites sp. cf. M. alveolatus & Polypodiaceae (Belvisia) & + & & & & + & & & \\
\hline Neoraistrickia sp. cf. $N$. suratensis & Selaginellaceae? & + & + & + & + & & & & \\
\hline Neoraistrickia sp. cf. N. taylorii & Selaginellaceae? & & & + & & & & & \\
\hline Polypodiisporites spp. & Polypodiaceae & + & & + & + & & & & \\
\hline Retitriletes spp. & Lycopodiaceae & + & + & + & & + & & + & + \\
\hline Ruffordiaspora australiensis & Schizaeaceae & + & + & + & + & + & & & + \\
\hline Stereisporites antiquasporites & Sphagnaceae & + & + & + & + & + & & & + \\
\hline S. australis & Sphagnaceae & & + & + & + & + & & + & + \\
\hline S. stellus $\mathrm{ms}$ & Sphagnaceae & & & & & + & & & \\
\hline S. sp. A of McKellar & Sphagnaceae & & + & & & & & & \\
\hline \multicolumn{10}{|l|}{ Gymnosperms } \\
\hline Araucariacites australis & Araucariaceae (Araucaria) & + & + & + & + & + & + & + & + \\
\hline Araucariacites sp. & Araucariaceae (Agathis) & & & + & & & & & \\
\hline Balmeiopsis limbata & Araucariaceae & & & + & & & & & \\
\hline Cupressacites & Cupressaceae & & & & & + & & + & + \\
\hline Cycadopites & Cycadaceae & & & & & & & & \\
\hline Dacrycarpites australiensis & Podocarpaceae (Dacrycarpus) & & + & + & & + & & + & + \\
\hline Dacrydiumites florinii & Podocarpaceae (Dacrydium) & & & + & + & + & & + & + \\
\hline Dilwynites granulatus & Araucariaceae (cf. Wollemia) & & + & + & + & + & + & + & + \\
\hline D. pusillus & Araucariaceae (cf. Wollemia) & & & & + & & & & \\
\hline Lygistepollenites balmei & Araucariaceae (cf. Wollemia) & $\mathrm{cf}$ & & & & & & & \\
\hline Microalatidites palaeogenicus & Podocarpaceae (Phyllocladus) & & & + & & & & + & + \\
\hline Microcachryidites antarcticus & Podocarpaceae (Microcachrys) & + & + & & + & + & & + & + \\
\hline Phyllocladidites mawsonii & Podocarpaceae (Lagarostrobos) & + & + & + & + & & + & + & \\
\hline P. reticulosaccatus & Podocarpaceae (Lagarostrobos) & & + & & + & & & + & \\
\hline Podocarpidites spp. & Podocarpaceae (Podocarpus) & + & + & + & + & + & + & & \\
\hline Podosporites cf. erugatus & Podocarpaceae (cf. Microstrobos) & + & & & + & & & + & \\
\hline Trichotomosulcites-Podosporites & Podocarpaceae (Microcachrys) & & + & + & + & & + & & \\
\hline Trisaccites variabilis & Podocarpaceae (Microcachrys) & + & + & + & + & & & & \\
\hline Vitreisporites pallidus & Extinct (Pteridospermatophyta) & & & + & & + & & & + \\
\hline \multicolumn{10}{|l|}{ Angiosperms (monocots) } \\
\hline Aglaoreidia qualumis & Sparganiaceae & & & & & + & & & \\
\hline Arecipites spp. & Arecaceae? & & + & + & & & & & \\
\hline Cyperaceaepollis neogenicus & Cyperaceae & & & & & + & & & \\
\hline Graminidites spp. & Poaceae & & & & & + & & & \\
\hline Liliacidites spp. & Liliaceae sensu lato & + & & & + & & & & \\
\hline Luminidites sp. cf. L. phormoides & Liliaceae sensu lato & & & & & + & & & \\
\hline Milfordia homeopunctata & Restionaceae (graminoid) & + & & & & & & & \\
\hline M. hypolaenoides & Restionaceae & + & & & & & & & \\
\hline \multicolumn{10}{|l|}{ Angiosperms (dicots) } \\
\hline Australopollis obscurus & Callitrichaceae & & & & + & + & & + & \\
\hline Banksieaeidites/Granodiporites & Proteaceae (Banksia?) & & & + & & & & & \\
\hline Battenipollis sectilis & Extinct clade & + & + & & & & & + & + \\
\hline Beaupreaidites elegansiformis & Proteaceae (Beauprea) & + & & & & + & & & \\
\hline B. verrucosus & Proteaceae (Beauprea) & + & & & & & & & \\
\hline
\end{tabular}


Table 2. (continued)

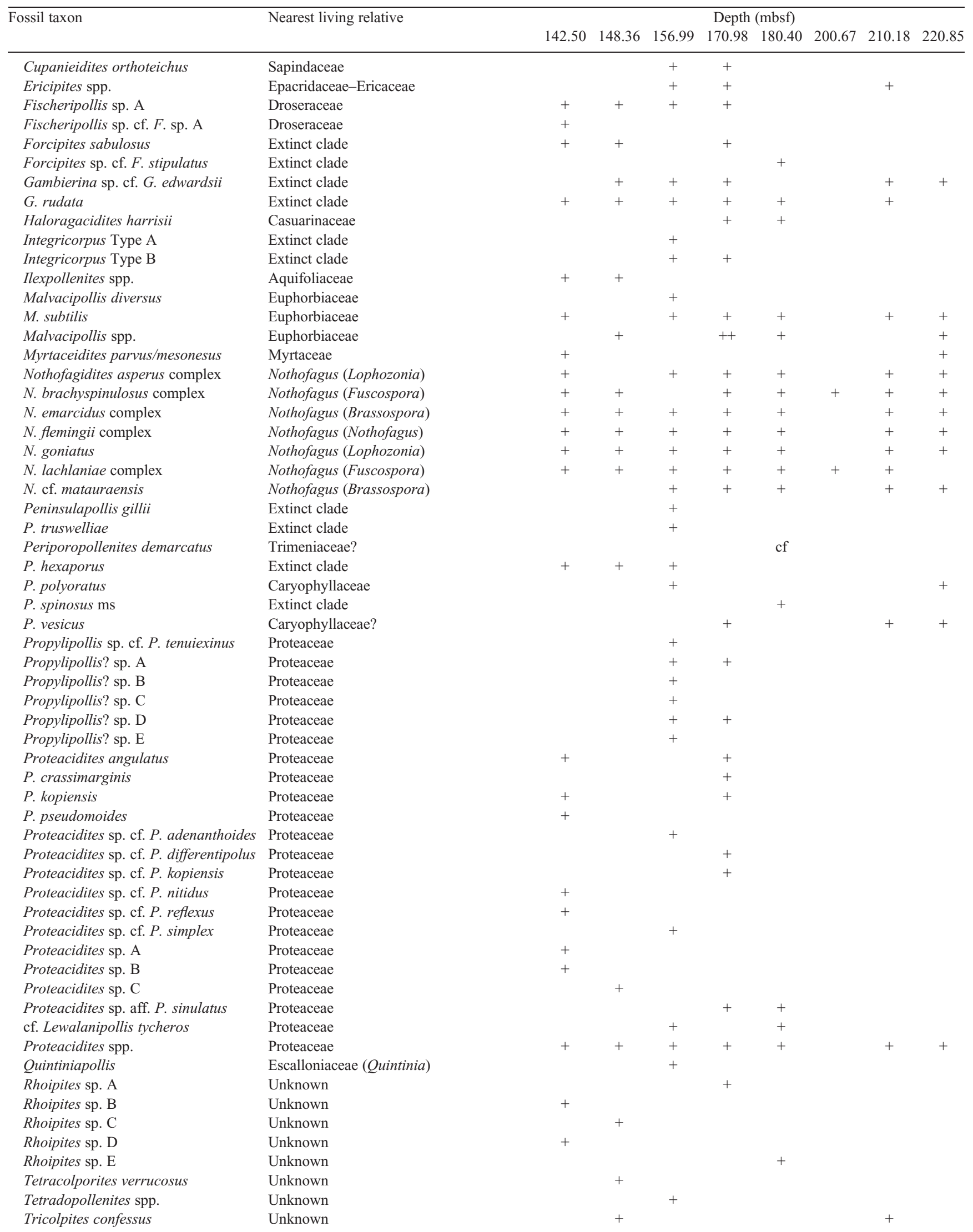


Table 2. (continued)

\begin{tabular}{|c|c|c|c|c|c|c|c|c|c|}
\hline \multirow[t]{2}{*}{ Fossil taxon } & \multirow[t]{2}{*}{ Nearest living relative } & \multicolumn{8}{|c|}{ Depth (mbsf) } \\
\hline & & 142.50 & 148.36 & 156.99 & 170.98 & 180.40 & 200.67 & 210.18 & 220.85 \\
\hline Tricolpites sp. cf. T. asperamarginis & Unknown & & & + & & & & + & + \\
\hline Tricolpites sp. A & Unknown & + & & & & & & & \\
\hline Tricolpites sp. B & Unknown & & & + & + & & & & \\
\hline Tricolpites sp. C & Unknown & & & & + & & & & \\
\hline Tricolpites sp. D & Unknown & & & + & & & & & \\
\hline
\end{tabular}

Coptospora sp. A of Dettmann 1963 (see plate 1, fig. $a$ in Raine and Askin 2001). The spores of the extant Bartramiaceae, for which we have modern reference material (Bartramia, Conostomum), are indistinctly hilate and ornamented, with irregular verrucae (M. K. Macphail and E. M. Truswell, unpubl. data).

\section{Sphagnaceae}

Stereisporites Thompson \& Pflug 1953 (Figs 8-15). Five morphotypes referable to Stereisporites were recorded at Site 1166. Two of these, S. antiquasporites (Wilson \& Webster) Dettmann 1963 (Fig. 12) and S. australis (Cookson) Krutzsch 1959 (Fig. 13), are smaller than, although otherwise identical to, the spores produced by living Sphagnum. A third morphotype (Figs 14, 15), informally referred to S. stellus ms by Truswell and Macphail (2004), is similar although it is presumed to be an extinct genus within the Sphagnaceae because the characteristic star-shaped thickening across the distal surface is not known to occur in spores produced by any extant Sphagnum species. Other specimens that are likely to represent extinct Sphagnaceae are morphotypes characterised by a well developed boss (Figs 8,9 ) and grana-verrucae on the distal surface (Figs 10, 11). The former morphotype has been accommodated within Stereisporites antiquasporites (see plate 2, fig. 3 in Sajjadi and Playford 2002b); the latter morphotypes may be variants of Stereisporites sp. A of McKellar (plate 2, fig. 4 in Sajjadi and Playford 2002b), respectively. Relative-abundance values are too low to infer the presence of Sphagnum (peatmoss) swamp or bog communities at Prydz Bay, despite the inferred cold and wet conditions.

\section{Hepaticopsida}

Like mosses, hepatics are common epiphytes in modern cool-cold vegetation types and their relative rarity in the Late Eocene vegetation at Prydz Bay is difficult to explain. Four morphotypes may represent Late Eocene hepatics (liverworts) cf. Belgisporis Krutzsch \& Vanhoorne 1977 (Figs 16, 17); apparently alete spores with finely plicate perine from the Ross Sea drillholes have been referred to the Marchantiales by Raine (1998) and Askin and Raine (2000), and to the Late Eocene Belgian genus Belgisporis Krutzsch \&Vanhoorne 1977 by Prebble et al. (2006), respectively. The specimens illustrated in Figs 16, 17 and that were assigned to Coptospora sp. by Raine and Askin (2001) may be the same morphospecies, although the Prydz Bay specimens are trilete and possess relatively robust plicate to? hamulate ornamentation. We note that one modern lycopsid family, the Selaginellaceae, also produces trilete spores with strongly plicate perine, e.g. Selaginella uliginosa.

Baculatisporites comaumensis (Cookson) Potonie 1956 (Figs 18, 19). Baculate trilete spores occur in trace to low numbers in most samples. The illustrated specimens are referred to the very long-ranging although typically Mesozoic species Baculatisporites comaumensis (Cookson) Potonie 1956, rather than the Tertiary species $B$. disconformis Stover \& Partridge 1973, because of the small size of the more or less equidimensional baculae. We note that spores of some Baculatisporites spp. closely resemble spores produced by the filmy fern family Hymenophyllaceae (Large and Braggins 1991, figs 272-295).

Neoraistrickia sp. cf. $\quad$ N. suratensis McKellar 1974 (Fig. 20). One specimen of a trilete spore ornamented with relatively short, recurved and sharp-tipped baculae is provisionally referred to the typically Jurassic species Neoraistrickia suratensis McKellar 1974. The dark colour suggests the spore may be reworked.

Neoraistrickia sp. cf. N. taylorii Playford \& Dettmann 1965 (Fig. 21). The illustrated specimen is characterised by its weakly concave subtriangular amb and long slender baculae.

\section{Lycophyta}

Two definite and four probable morphospecies of lycopsids are recorded in trace numbers in Site 1166. Most are similar to species found in Mesozoic deposits and it is unclear whether the specimens found at Site 1166 are in situ or reworked.

Leptolepidites sp. cf. L. verrucatus Couper 1953 (Fig. 22). This trilete spore is widespread in Middle Jurassic to Early Cretaceous deposits in Australia and New Zealand (see Sajjadi and Playford 2002a) and a closely related morphotype reappears in Late Miocene-Early Pliocene microfloras in southern Australia (Macphail 1997). The taxonomic affinity of the parent plant(s) at Prydz Bay is unclear.

Foveosporites sp. cf. F. canalis Balme 1957 (Fig. 23). One specimen of this morphospecies was found at Prydz Bay. The wide cingulum is similar to that found in $F$. canalis Balme 1957, although the elliptical foveolae differ from the foveo-vermiculate sculpture of the latter species (see plate 13, figs 1, 2 in Sajjadi and Playford 2002a). The cingulum in $F$. pseudoalveolatus (Couper) McKellar is less well developed (see plate 13, figs 3-7 in Sajjadi and Playford 2002a) although the circular-elliptical foveolae are more closely spaced than in the Prydz Bay specimen. Both species are restricted to Late Jurassic to Early Cretaceous sequences in Australia. The Prydz Bay specimen lacks the kyrtomes characteristic of the Tertiary species $F$. balteus 

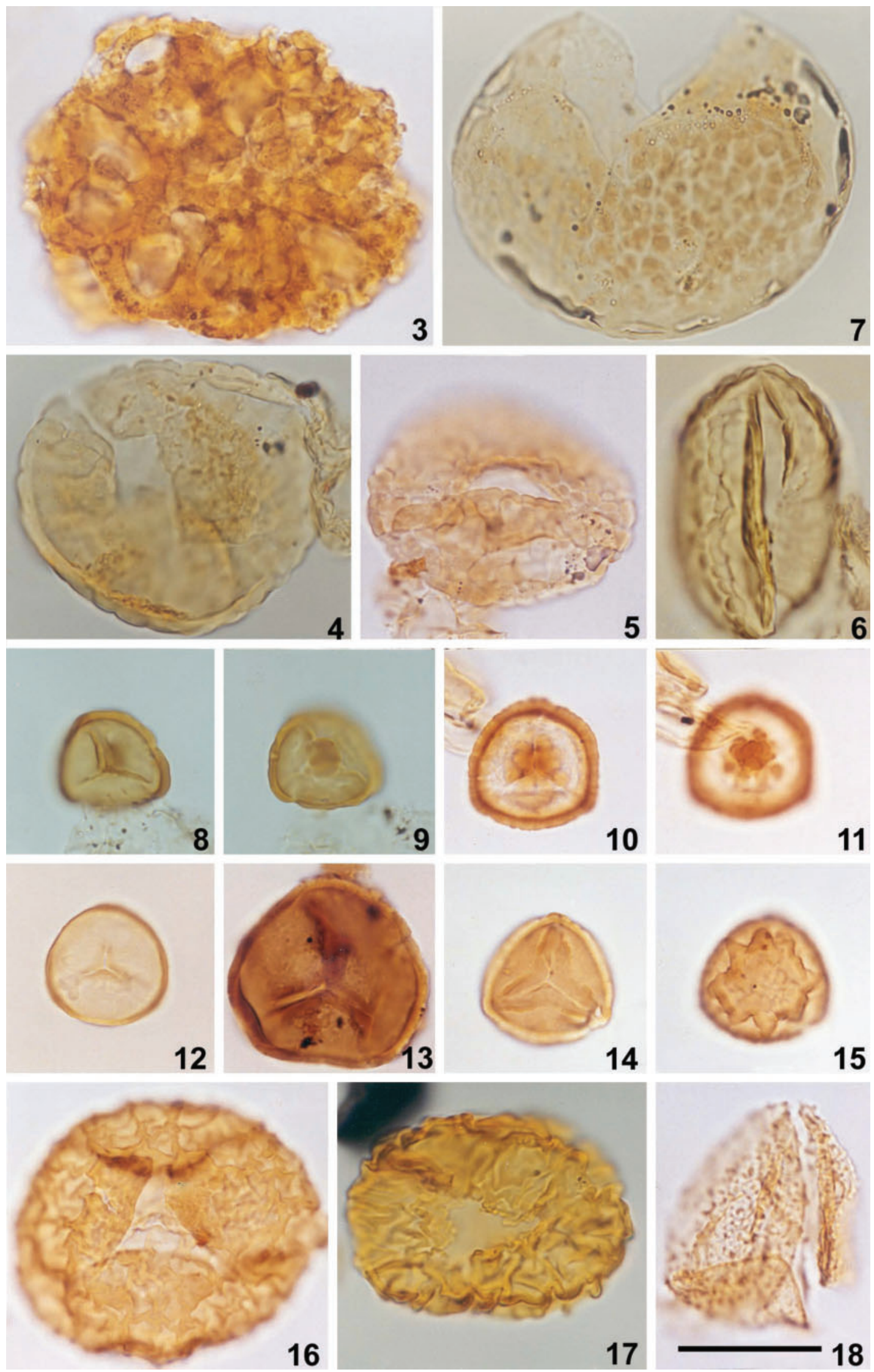
Stover \& Partridge 1973, whereas F. lacunosus Stover \& Partridge 1973 has a psilate proximal surface and less well developed marginal lips to the laesurae than $F$. canalis. The spore is considered to be an extinct species of Lycopodiaceae whose spores broadly resemble those produced by living Lycopodium cernum (see figs 22-24 in Large and Braggins 1991).

Retitriletes sp. cf. R. eminulus Dettmann 1963 (Fig. 24). The figured species resembles spores from the McMurdo erratics that were assigned to cf. $R$. eminulus by Askin (2000). It differs from specimens referred to $R$. australoclavatidites (Cookson) Doring et al. 1963 only in the finely reticulate nature of the perine covering the distal surface. Prebble et al. (2006, fig. 5a) illustrated what appears to be the same morphospecies. The spore almost certainly represents an extinct species of Lycopodiaceae.

Retitriletes australoclavatidites (Cookson) Doring et al. 1963 (Figs 25, 26). Spores produced by the living species Lycopodium fastigiatum are similar to those of $R$. australoclavatidites (see figs 34-36 in Large and Braggins 1991). The morphospecies first appears in the Rhaetian (see de Jersey and Raine 1990) and is found in the McMurdo erratics (Askin 2000), as well as being the most commonly recorded species in Tertiary sediments in Australia, e.g. Macphail and Hill (1994).

Two other Retitriletes species are represented by trace numbers of spores (Figs 27, 28). The morphotype illustrated in Fig. 27 is characterised by bifurcating laesurae on the proximal surface; the morphotype illustrated in Fig. 28 by a reticulate perine in which the muri are partially broken.

\section{Pterophyta}

Spores produced by ground ferns and possible tree-ferns are numerically more abundant than those of other cryptogams. None occurs in sufficient numbers to indicate the parent ferns were prominent in the Late Eocene vegetation, especially since fern spores are widely dispersed into and by water. This contrasts with modern cool-cold temperate rainforests in the southern hemisphere, where ferns are common on the forest margins and in analogous damp, open environments such as river banks. A minimum of four families is represented by seven described and undescribed species.

\section{Polypodiaceae?}

Monolites sp. cf. M. alveolatus Couper 1960 (Figs 29, 30). Two finely pitted (scrobiculate) monolete spores that differ only marginally in length have been assigned to this species complex. The spore type is similar to those produced by the tropical fern genus Belvisia (Polypodiaceae) but also to the weakly corroded psilate spores of fern families such as the Blechnaceae. A probable representative of the last family, Laevigatosporites ovatus Wilson \& Webster 1946, is a consistent but rare species in the McMurdo erratics. Laevigatosporites spp. occurs in trace numbers in Oligocene and Miocene glacimarine sediments cored by the Cape Roberts Project, where they are listed as reworked by Raine (1998).

Polypodiisporites Potonie \& Gelletich ex Potonie 1956 (Figs 39-41). Two monolete spores characterised by well developed verrucae or verruco-reticulate sculpture are referred to this form genus. The specimen illustrated in Fig. 39 appears to be larger than, although otherwise identical to, morphospecies found recycled in the Ross Sea (see plate 2, figs 2, 3 in Truswell 1983). The specimen illustrated in Figs 40, 41 is similar to $P$. histiopteroides (Krutzsch) Nagy 1973. Living ferns producing similar spores occur in the Davalliaceae (Davallia, Nephrolepis), Dennstaedtiaceae (Histiopteris) and Polypodiaceae (Microsorium, Phymatosorus, Polypodium) in Australia, New Zealand and southern South America.

\section{Cyatheaceae?}

Cyathidites Couper 1953/Dictyophyllidites Cookson \& Dettmann 1958 (Figs 31, 32). Small thin-walled psilate trilete spores occurring at Prydz Bay are assigned to the longranging Cyathidites australis-minor complex of Couper 1953 (not illustrated). The much larger specimens illustrated in Figs 31, 32 lack the valvae diagnostic of Matonisporites (NLRs Dicksoniaceae, Matoniaceae) and the exine is much thicker than in most Cyathidites spp. Possible identifications are Cyathidites asper (Bolchovitina) Dettmann 1963 and Dictyophyllidites equiexinus (Couper) Dettmann 1963. The laesurae of one specimen (Fig. 32) are bordered by shallow foveolae. Essentially, the same spore morphotype is produced by living species of Cyathea (Cyatheaceae) and also by other fern families, e.g. Adiantaceae. If confirmed, the presence of

Figs 3-18. Fig. 3. Botryococcus; spherical colony in polar view; $142.5 \mathrm{~m}$ below the modern sea floor (mbsf). Figs 4-6. Coptospora archangelskyi Zamaloa 2004. Fig. 4. Crushed spore in polar view, showing verrucate ornamentation; shape of aperture obscured; 148.36 mbsf. Fig. 5. Crushed monolete? spore in polar view, showing verrucate ornamentation; aperture with thickened margins; 148.36 mbsf. Fig. 6. Laterally compressed monolete? spore in polar view, showing verrucate ornamentation; aperture with thickened margins; 142.5 mbsf. Fig. 7. cf. Coptospora archangelskyi Zamaloa 2004; crushed monolete? spore in oblique equatorial, showing verrucate ornamentation; aperture with unthickened margins; 148.36 mbsf. Figs 8, 9. Stereisporites antiquasporites sensu Sajjadi and Playford 2002b; trilete spore in polar view, showing psilate proximal surface, well developed boss on distal surface and thick cingulum relative to spore diameter; 148.36 mbsf. Figs 10, 11. Stereisporites sp. cf. S. sp. A of McKellar (in Sajjadi and Playford 2002b); trilete spore in polar view, showing striate cingulum, and distal surface ornamented with fused granules; 156.99 mbsf. Fig. 12. S. antiquasporites (Wilson and Webster) Dettmann 1963; trilete spore in polar view, showing psilate proximal surface; 156.99 mbsf. Fig. 13. S. australis (Cookson) Krutzsch 1959; trilete spore in polar view, showing \pm psilate proximal face; 148.36 mbsf. Figs 14,15. S. stellus $\mathrm{ms}$; trilete spore in polar view, showing faintly scabrate proximal face with well developed thickenings (kyrtomes) along the laesurae, and stellate thickening on distal surface; $180.4 \mathrm{mbsf}$. Figs 16, 17. cf. Belgisporis Krutzsch and Vanhoorne 1977. Fig. 16. Compressed trilete spore in polar view, showing hamulate-reticulate ornamentation on proximal face (which extends across distal surface) and well defined margins to laesurae; 148.36 mbsf. Fig. 17. Compressed trilete spore in polar view, showing hamulate-reticulate ornamentation on proximal face and ragged margins to laesurae; 148.36 mbsf. Fig. 18. Baculatisporites comaumensis (Cookson) Potonie 1956; crushed trilete spore in polar view, showing irregular baculae scattered across proximal and distal surfaces; $156.99 \mathrm{mbsf}$. Scale bar $=25 \mu \mathrm{m}$. 

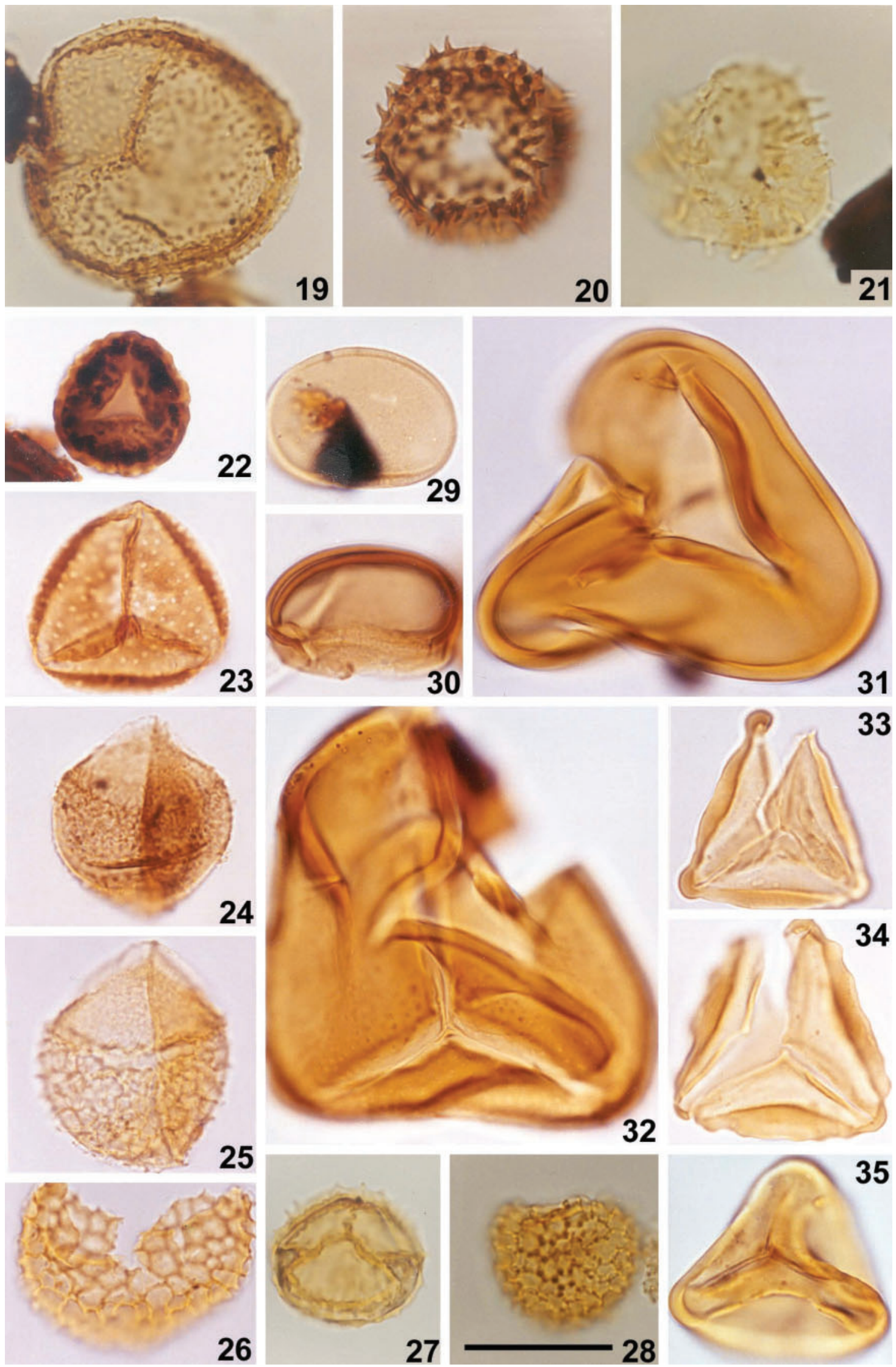
Cyatheaceae would indicate climates at Prydz Bay during the Late Eocene were sufficiently benign to support tree-ferns. Cyathidites occurs in trace numbers in the McMurdo erratics (Askin 2000) and in Oligocene glacimarine sediments (one specimen) (Prebble et al. 2006).

\section{Gleicheniaceae}

Two to possibly three morphotypes representing extinct species within the coral-fern family Gleicheniaceae were recorded.

Clavifera triplex (Bolkhovitina) Bolkhovitina 1956 (Fig. 33). Distinctive interradial crassitudes confirm this spore is a fossil species of Gleicheniaceae (see figs 172-178 in Large and Braggins 1991), although no living species produces spores with rounded 'knobs' (auriculae) on the apices. The morphospecies first appears in the Cenomanian and becomes extinct in the Late Paleocene in south-eastern Australia. It has been reported from the Late Cretaceous Seymour Island sequence (Askin 1990b). Other specimens have been recorded in Paleocene sediments on the Ninetyeast Ridge (Kemp and Harris 1977) and as a recycled element in Ross Sea and Shackleton Ice Shelf muds (Truswell 1983).

Gleicheniidites ancorus ms (Fig. 34). This manuscript species (Partridge 1999) differs from G. circiniidites Cookson 1953 in that the interradial crassitudes have a wavy outline and terminate in distinct scallops. G. ancorus ms first appears in the Cenomanian in southern Australia and ranges into the Early Eocene (Partridge 1999). It is uncertain whether the Prydz Bay specimens are in situ or reworked because the morphotype is absent in the McMurdo erratics and Oligo-Miocene glacimarine cores, whereas it occurs in Eocene sediments in the northern Weddell Sea (Mohr 1990).

Dictyophyllidites sp. cf. D. arcuatus Pocknall \& Mildenhall 1984 (Fig. 35). The illustrated specimen, which is characterised by well developed kyrtomes that extend the length of the laesurae, is similar to D. arcuatus described by Pocknall and Mildenhall (1984) from Early Miocene deposits in Southland, New Zealand, although it lacks the pointed apices of the latter species. An alternative identification is D. harrisii Couper 1958, which is common in Middle Jurassic sequences in south-western Western Australia. Pocknall and Mildenhall (1984) compared D. arcuatus to spores produced by the tropical Gleicheniaceae genus Dicranopteris.

\section{Schizaeaceae}

Cicatrose trilete spores, which closely resemble spores produced by two, now wholly tropical genera of Schizaeaceae, occur in trace numbers in the Late Eocene section. It is uncertain whether the Prydz Bay specimens are in situ or reworked because similar morphotypes occur in Cretaceous sequences in Antarctica.

Ruffordiaspora australiensis (Cookson) Dettmann \& Clifford 1992 (Fig. 36). The illustrated specimen resembles spores produced by the tropical fern genera Anaemia; however, a much closer match are spores recovered from the Cretaceous macrofossil species Ruffordia goeppertii (Dunkert) Seward 1894 (see Dettmann 1994). The specimen illustrated in Fig. 37 differs from $R$. australiensis in that the irregular muri anastomose towards the amb. Norvick and Burger (1976) reported a similar morphotype (Cicatricosisporites sp. A) from Cenomanian sediments on Bathurst Island, Northern Territory.

Appendicisporites sp. cf. A. crassicarinatus Harris 1977 (Fig. 38). The specimen recovered from $156.99 \mathrm{mbsf}$ fits well with the modified diagnosis of the form genus Appendicisporites given by Dettmann and Clifford (1992), in having distal muri that are narrower than the intervening luminae, and that fuse to form a series of projections at the radial junctions. The form genus accommodates spores comparable to those of the tropical-subtropical genus Anaemia. The Prydz bay specimen differs only marginally from A. crassicarinatus, described from both Paleocene and Oligocene sites on the Ninetyeast Ridge (Kemp and Harris 1977). The presence of the species at Prydz Bay would represent an extension of its stratigraphic range into the Eocene. Its similarity to in situ Ninetyeast Ridge specimens, where they are unlikely to be reworked, is circumstantial evidence that the Prydz Bay spore may also be in situ, although we note that similar spores have been found in probable Albian sediments drilled on ODP Leg 119 in Prydz Bay (Truswell 1991).

Figs 19-35. Fig. 19. Baculatisporites comaumensis (Cookson) Potonie 1956; distorted trilete spore in polar view, showing irregular baculae scattered across proximal and distal surfaces; $156.99 \mathrm{~m}$ below the modern sea floor (mbsf). Fig. 20. Neoraistrickia sp. cf. N. suratensis McKellar 1974; trilete spore in polar view, showing distal surface ornamented with baculae; 156.99 mbsf. Fig. 21. Neoraistrickia sp. cf. N. taylorii Playford \& Dettmann 1965; trilete spore in polar view, showing long baculae on distal surface and around the equator; $156.99 \mathrm{mbsf}$. Fig. 22. Leptolepidites sp. cf. L. verrucatus Couper 1953; trilete spore in polar view, showing dome-like verrucae on distal surface and around the equator; 156.99 mbsf. Fig. 23. Foveosporites sp. cf. F. canalis Balme 1957; trilete spore in polar view, showing raised membranous laesurae on proximal surface and numerous shallow discrete foveolae on distal surface; 156.99 mbsf. Fig. 24. Retitriletes sp. cf. R. eminulus Dettmann 1963; trilete spore in equatorial view showing psilate proximal surface and finely reticulate perine covering the distal surface and; 148.36 mbsf. Figs 25, 26. $R$. australoclavatidites (Cookson) Krutzsch et al. 1963. Fig. 25. Trilete spore in equatorial view, showing psilate proximal surface and even open reticulate perine covering the distal surface; $142.5 \mathrm{mbsf}$. Fig. 26. Crushed trilete spore in polar view, showing even open reticulate perine covering the distal surface; $142.5 \mathrm{mbsf}$. Fig. 27. Retitriletes sp.; trilete spore in polar view, showing psilate proximal surface; 156.99 mbsf. Fig. 28. Retitriletes sp.; trilete spore in polar view, showing uneven open reticulate perine covering the distal surface; $156.99 \mathrm{mbsf}$. Figs 29, 30. Monolites sp. cf. M. alveolatus Couper 1960. Fig. 29. Monolete spore in equatorial view, showing closely spaced scrobiculi; $142.5 \mathrm{mbsf}$. Fig. 30. Monolete spore in oblique equatorial view, showing thickened exine along the laesurae; 180.4 mbsf. Figs 31, 32. Cyathidites/Dictyophyllidites sp. Fig. 31. Torn trilete spore in polar view, showing thickened exine along the laesurae; $142.5 \mathrm{mbsf}$. Fig. 32. Torn trilete spore in polar view, showing scattered punctae along the laesurae; 156.99 mbsf. Fig. 33. Clavifera triplex (Bolkhovitina) Bolkhovitina 1956; trilete spore in polar view, showing inter-radial crassitudes and incipient development of auriculae. Fig. 34. Gleicheniidites ancorus Partridge 1999; trilete spore in polar view, showing scalloped inter-radial crassitudes; 156.99 mbsf. Fig. 35. Dictyophyllidites sp. cf. D. arcuatus Pocknall \& Mildenhall 1984; trilete spore in polar view, showing well developed kyrtomes on the proximal surface; $142.5 \mathrm{mbsf}$. Scale bar $=25 \mu \mathrm{m}$. 

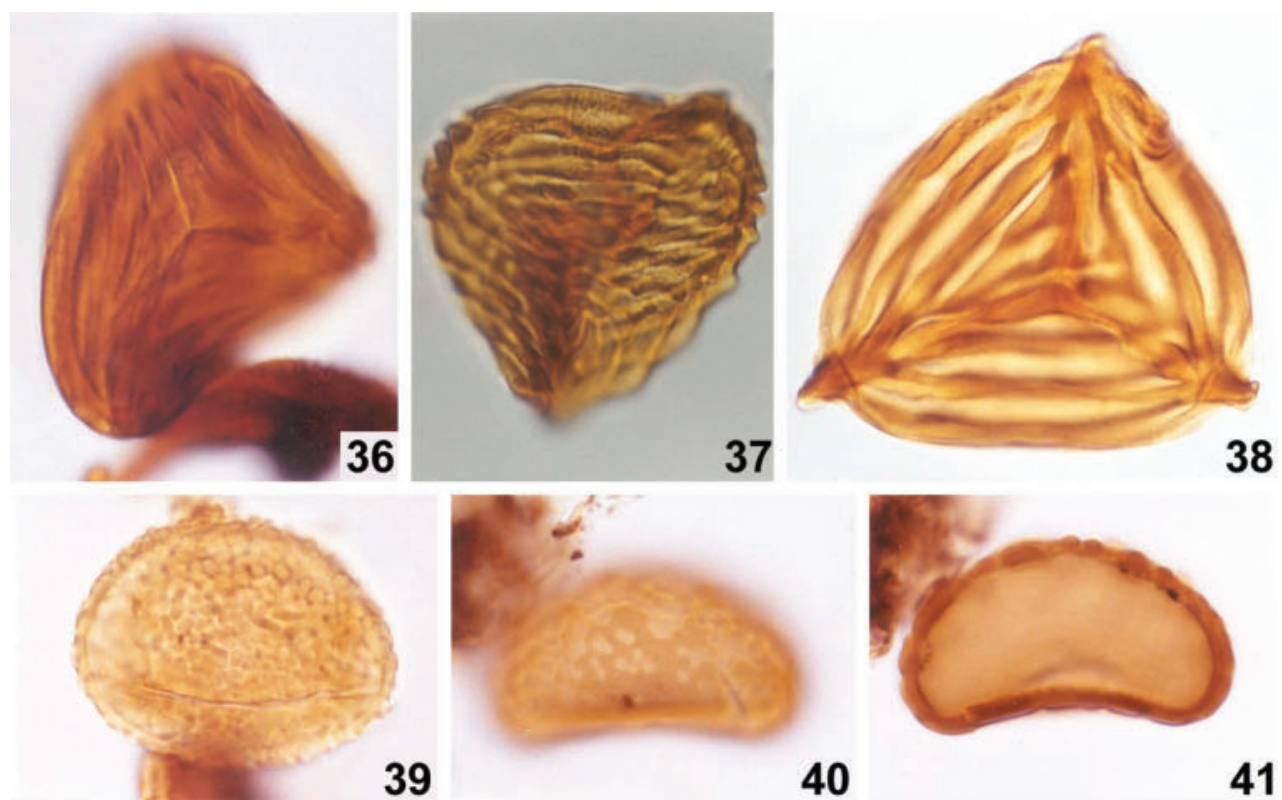

39

40
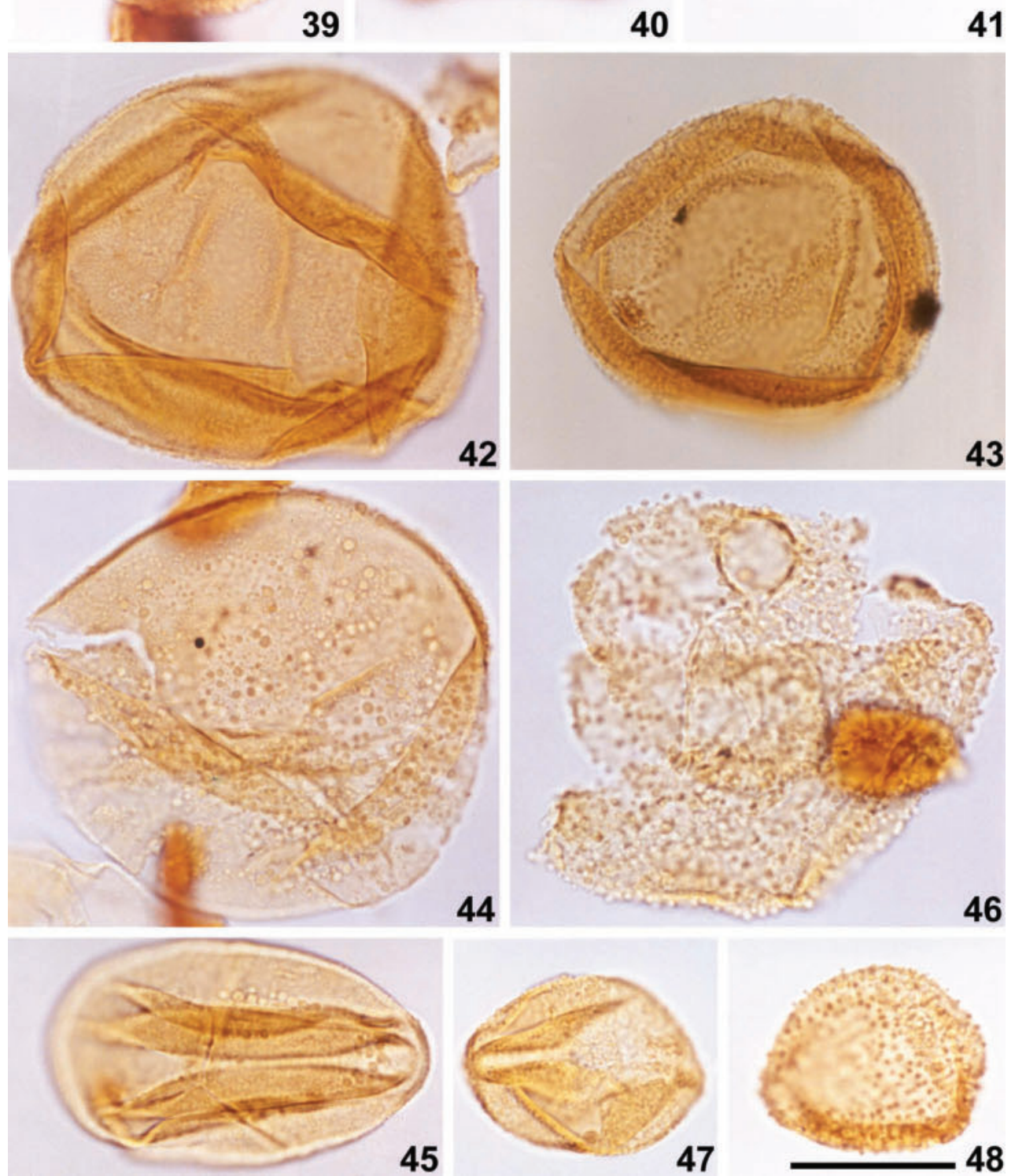


\section{Coniferophyta}

A minimum of three conifer (gymnosperm) families is represented by inaperturate, bisaccate and trisaccate pollen types at Prydz Bay - Araucariaceae (3 or 4 genera), Cupressaceae-Taxodiaceae (1 genus) and Podocarpaceae ( $>4$ genera). Relative pollen abundance values are variable, up to $35-40 \%$. Overall abundances are lower than values recorded during the Late Cretaceous (Macphail and Truswell 2004a), suggesting some gymnosperms were competitively disadvantaged by increasingly cold conditions during the Palaeogene. While none of the NLRs of the fossil species and genera grow today under conditions of prolonged winter darkness, experimental data on living genera such as Athrotaxis, Lagarostrobos and Phyllocladus show they are able to survive extended periods of winter darkness (Read and Francis 1992). Nonetheless, it remains probable that the parent plants of the Prydz Bay microflora represent extinct ecotypes or species and, less certainly, extinct genera.

\section{Araucariaceae}

Araucariacites australis Cookson 1947 (Fig. 42). The very finely granulate ornamentation indicates this inaperturate fossil pollen type was produced by a fossil species of Araucaria rather than the other two extant genera of Araucariaceae (Agathis, Wollemia). Relative-abundance values decline from $\sim 16 \%$ to trace values during the Middle to Late Eocene. This is ecologically consistent with the restriction of most living Araucaria species to warm temperate-tropical (lower mesotherm-megatherm) environments although we note that (1) one extant species, A. araucana, is common in montane-subalpine forests between $\sim 37^{\circ}$ and $40^{\circ} \mathrm{S}$ in southern South America (Veblen et al. 1995, fig. 6.4) and (2) Early Cretaceous and early Tertiary species of Araucariaceae extended into high latitudes. Araucariacites australis occurs in trace numbers in the McMurdo erratics, and scale leaves of Araucaria are known from the same source (Pole et al. 2000). Araucaria macrofossils are recorded in abundance from Paleocene and Eocene strata on Seymour Island (Case 1988; Stephens in Francis et al. 2008). There, the flora within an Eocene unit of the La Meseta Formation is dominated by leaves, cones scales and branchlets of a fossil form of the genus, with similarities to living Araucaria araucana. In Middle Eocene marine sediments on the East Tasman Plateau
(ODP Site 1172A), Araucariacites pollen values range from a trace up to $11 \%$ (M. K. Macphail, unpubl. data).

Araucariacites sp. cf. A. australis Cookson 1947 (Figs 43, 47). The illustrated specimens differ from A. australis Cookson 1947 in that the grains are smaller, markedly so in the case of Fig. 47, and ornamented by fine granules. The morphotype illustrated in Fig. 43 is similar to pollen produced by Australian species of Agathis.

Dilwynites granulatus Harris 1965 (Fig. 46). This fossil species is distinguished from Araucariacites australis by its relatively coarse granulate ornamentation. Essentially, the same pollen type is produced by the recently discovered Wollemia nobilis (see Macphail et al. 1995) and also by one or more unidentified species of Agathis (M. K. Macphail, unpubl. data). The Prydz Bay microflora includes small to large specimens, with a much sparser ornamentation of coarse granules (Figs 44, 45), referred to here as D. sp. cf. $D$. granulatus, and a small grain in which the sculptural elements include coni as well as granules (Fig. 48). The last morphotype may be a variant of the manuscript species Dilwynites pusillus, described by Partridge (1999) from Turonian-Santonian sediments in the Gippsland Basin. D. granulatus is present although rare in the Early Oligocene section of Cape Roberts cores, from an interval where the microflora is believed to have represented the in situ vegetation (Prebble et al. 2006). A related species characterised by coarse tuberculate sculpture, D. tuberculatus Harris 1965, has been recovered from Recent sediments in the Ross Sea (Truswell 1983). Relative-abundance values recorded in Middle Eocene marine sediments on the East Tasman Plateau (ODP Site 1172A) range from trace up to $12 \%$ (M. K. Macphail, unpubl. data).

Balmeiopsis limbata (Balme) Archangelsky 1979 (Fig. 49). This pollen type, produced by an extinct clade (brachyphyll araucarians) of Araucariaceae, is unlikely to be in situ because the morphotype is restricted to Cretaceous sequences in present-day western and north-western Australia and is absent in Tertiary sediments recovered from the South Tasman Rise. B. limbata was recorded in Late Cretaceous sequences from James Ross Island (Dettmann and Thomson 1987). Its occurrence in Antarctica strengthens links between palaeo-western Australia (see Macphail and Truswell 2004a) and also southern South America, where a closely related morphotype Cyclusphaera Elsik 1966 has been used to

Figs 36-48. Fig. 36. Ruffordiaspora australiensis (Cookson) Dettmann \& Clifford 1992; trilete spore in polar view, showing \pm straight, psilate muri prominently developed on the distal surface; $156.99 \mathrm{~m}$ below the modern sea floor (mbsf). Fig. 37. Ruffordiaspora sp. of Norvick and Burger 1976; trilete spore in oblique equatorial view, showing irregular (nodulated) muri, which coalesce to form pseudofovea near the amb; 148.36 mbsf. Fig. 38. Appendicisporites sp. cf. A. crassicarinatus Harris 1977; trilete spore in polar view, showing widely spaced muri on the proximal and distal surfaces, which coalesce to form prominent projections (valvae) at the corners;156.99 mbsf. Fig. 39. Polypodiisporites sp.; monolete spore in oblique equatorial view, showing closely spaced verrucae and well defined elongate laesura; 156.99 mbsf. Figs 40, 41. Polypodiisporites sp. aff. P. histiopteroides (Krutzsch) Nagy 1973. Fig. 40. Monolete spore in surface equatorial view, showing irregularly spaced verrucae outlining pseudofovea; $170.98 \mathrm{mbsf}$. Fig. 41. Same spore in median equatorial view, showing irregularly spaced verrucae. Fig. 42. Araucariacites australis Cookson 1947; compressed inaperturate pollen ornamented with very fine granules; 156.99 mbsf. Fig. 43. Araucariacites sp. cf. A. australis Cookson 1947; compressed inaperturate pollen ornamented with medium fine granules; 170.98 mbsf. Fig. 44. Dilwynites sp. cf. D. granulatus Harris 1965; torn inaperturate pollen sparsely ornamented with medium to coarse granules; 156.99 mbsf. Fig. 45. Dilwynites sp. cf. D. granulatus Harris 1965; inaperturate pollen very sparsely ornamented with medium to coarse granules; 156.99 mbsf. Fig. 46. Dilwynites granulatus Harris (1965); torn inaperturate pollen densely ornamented with medium to coarse granules; 142.5 mbsf. Fig. 47. Araucariacites sp. cf. A. australis Cookson 1947; small inaperturate pollen ornamented with very fine granules; $142.5 \mathrm{mbsf}$. Fig. 48. . pusillus Partridge 1999; small inaperturate pollen densely ornamented with medium granules and baculae; $170.98 \mathrm{mbsf}$. Scale bar $=25 \mu \mathrm{m}$. 

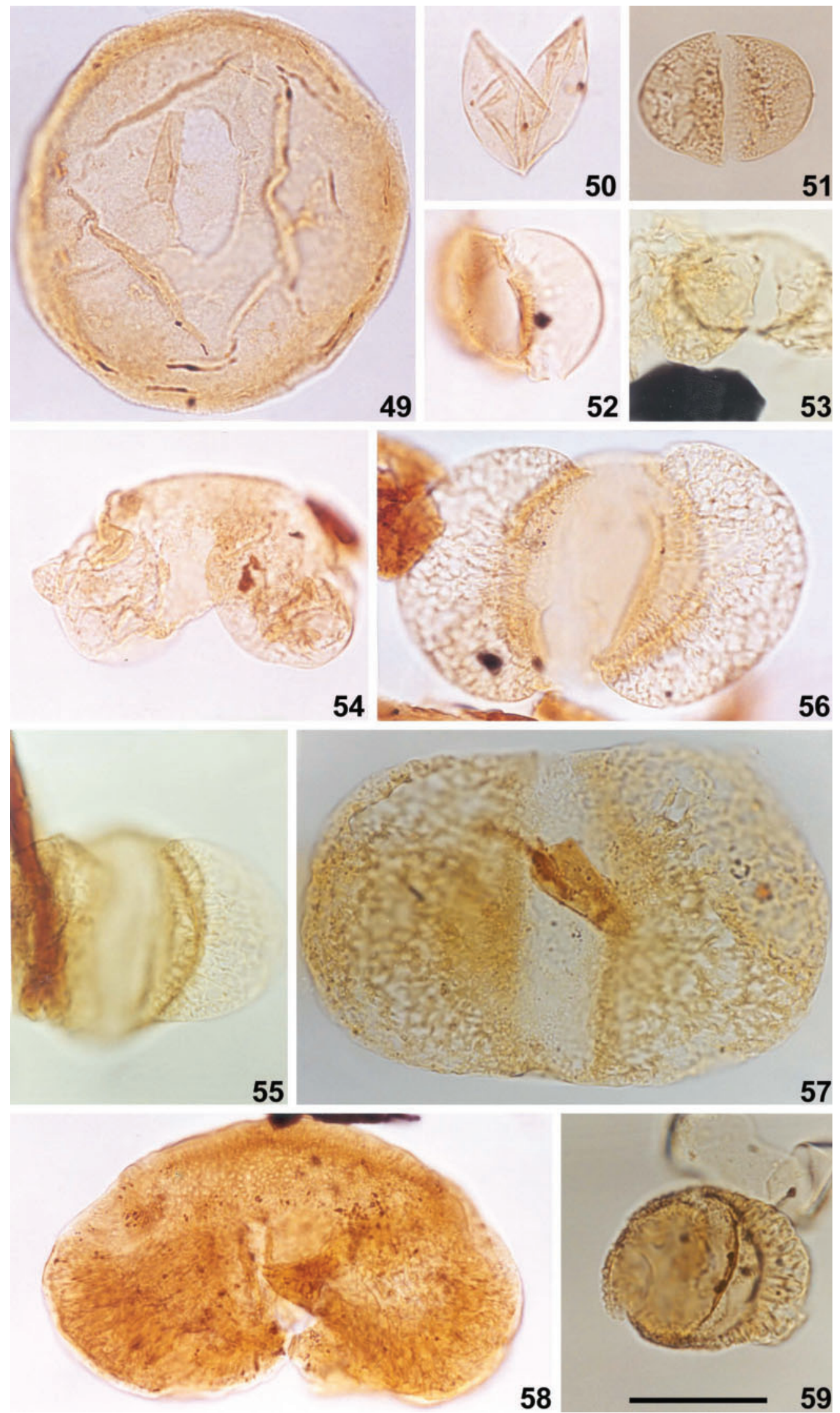
define a palaeofloristic subprovince within Southern Gondwana during the Early Cretaceous (see Del Fueyo and Archangelsky 2005). Bisaccate pollen types produced by two extinct pteridosperms (Pteridospermophyta) - Alisporites grandis (Cookson) Dettmann 1963 (Fig. 57) and Vitreisporites pallidus (Reissinger) Nilson 1958 (Fig. 51) - are part of the same (recycled Mesozoic) component. V. pallidus is known to occur in the Triassic Victoria Group of the Transantarctic Mountains (Kyle and Schopf 1982).

\section{Cupressaceae-Taxodiaceae}

Cupressacites (Bolkhovitina) Bolkhovitina 1956 (Fig. 50). This subsphaerical to ellipsoidal split pollen type is identical to pollen produced by living Cupressaceae and Taxodiaceae and also is not dissimilar to the compressed cysts of some freshwater algae or Isoetes spores that have been stripped of their perine (M. K. Macphail, unpubl. obs.). Nevertheless, the presence of Cupressaceae and/or Taxodiaceae at Prydz Bay would not be inconsistent with the modern distribution of Diselma archeri (Cupressaceae) and Athrotaxis spp. (Taxodiaceae) in alpine coniferous heath in Tasmania (Crowden 1999). Another Cupressaceae, Librocedrus bidwilli, forms the timber-line forests in New Zealand (Ogden and Stewart 1995). Values up to $2 \%$ are recorded at Prydz Bay; three specimens occur in the McMurdo erratic samples (Askin 2000).

\section{Podocarpaceae}

A minimum of nine fossil species can be assigned to extant genera within the Podocarpaceae (Dacrycarpus, Lagarostrobos, Phyllocladus, Microcachrys, Podocarpus-Prumnopitys). Significantly, most of the extant genera include species that range into the modern subalpine-alpine vegetation in Australia, New Zealand and southern South America (references in Enright and Hill 1995). One species complex (Podosporites-Trichotomosulcites) is extinct, although it appears to be related to the alpine creeping pine Microcachrys tetragona, endemic to Tasmania.

Dacrycarpites australiensis Cookson \& Pike 1953 (Figs 77-79). The NLRs of this large trisaccate pollen type (Dacrycarpus) are dominants in coastal (kahikatea) swamp forest in southern New Zealand (Ogden and Stewart 1995) and extend into the montane and lower subalpine rainforests of tropical Australasia (Enright 1995). D. australiensis first occurs in the Campanian in south-eastern Australia, and has been reported from Campanian-Maastrichtian sediments from the Antarctic Peninsula (Dettmann and Thomson 1987), where it extends at least into the Danian (Askin 1990a). The rarity of the fossil pollen type at Prydz Bay and in the McMurdo Sound glacial erratics is strongly against Dacrycarpus forming coastal swamp communities in East Antarctica during the Middle-Late Eocene. The species has not been recorded in Oligo-Miocene sequences in the Cape Roberts drillholes (Askin and Raine 2000; Prebble et al. 2006), nor in the Weddell Sea sequences in West Antarctica (Mohr 1990).

Dacrydiumites (al. Lygistepollenites) florinii Cookson \& Pike 1953 (Fig. 59). Dacrydiumites florinii previously has been recorded as D. praecupressinoides (Couper 1953) Truswell 1983 by Askin (2000) in the McMurdo erratics, in Miocene glacimarine sediments in the Cape Roberts Drillhole CRP-1 (Raine 1998) and as a recycled element in the Ross Sea (Truswell 1983). The NLRs of this distinctive morphospecies (Dacrydium) are widely spread throughout the south-western Pacific region and reach their maximum diversity in tropical New Guinea. The majority of species are restricted to rainforests at lower to moderate elevations (Enright 1995) and the low to trace pollen values recorded are ecologically consistent with cool rather than cold conditions at Prydz Bay.

Lygistepollenites sp. cf. L. balmei (Cookson) Stover \& Evans 1973 (Fig. 58). The large bisaccate pollen grain illustrated in Fig. 58 is characterised by thickened rod-like muri within the sacci. The closest formally described morphospecies is L. balmei, a probable tall conifer that first appears in the Santonian and that may have dominated Austral Conifer Forest in south-eastern Australia during the Early Paleocene (see Macphail et al. 1994).

Microalatidites palaeogenicus (Cookson \& Pike) Mildenhall \& Pocknall 1989 (Fig. 60). This morphotype, which is characterised by vestigial, long narrow sacci, closely resembles pollen produced by living Phyllocladus and is not dissimilar to rare bisaccate grains found in populations of (trisaccate) Podosporites microsaccatus Couper 1953 (included in the Podosporites-Trichotomosulcites species complex). As such, it is unclear whether Phyllocladus was part of the late Eocene flora at Prydz Bay. Askin (2000) recorded Microalatidites palaeogenicus and, more frequently, the related species M. varisaccatus Pocknall \& Mildenhall 1984 in the

\footnotetext{
Figs 49-59. Fig. 49. Balmeiopsis limbata (Balme) Archangelsky 1979. Compressed pollen grain in polar view, showing characteristic thickening of the exine around the rim and thinning and rupturing of the exine across the pole; $156.99 \mathrm{~m}$ below the modern sea floor (mbsf). Fig. 50. Cupressacites sp.; compressed ellipsoidal pollen grain showing characteristic longitudinal split; 180.4 mbsf. Fig. 51. Vitreisporites pallidus (Reissinger) Nilson 1958; small bisaccate pollen grain in distal polar view, with sharply defined, narrow sulcus on distal surface; 156.99 mbsf. Fig. 52. Podocarpidites sp.; small bisaccate pollen grain in oblique distal polar view, showing incomplete reticulum within the saccus; 156.99 mbsf. Fig. 53. Podocarpidites sp.; small bisaccate pollen grain in oblique distal polar view, showing sharply defined proximal roots of sacci; 156.99 mbsf. Fig. 54. Podocarpidites sp.; intermediate sized pollen grain in oblique equatorial view, showing sharply defined proximal roots of sacci; $156.99 \mathrm{mbsf}$. Fig. 55. Podocarpidites sp.; intermediate-sized pollen grain in oblique distal polar view, showing sharply defined proximal roots of sacci and distal sulcus; 180.4 mbsf. Fig. 56. Podocarpidites sp. cf. Podocarpidites marwickii Couper 1960; large bisaccate pollen grain in distal polar view, showing sharply defined proximal roots of sacci and sulcus on the distal surface; 156.99 mbsf. Fig. 57. Alisporites grandis (Cookson) Dettmann 1963; large bisaccate pollen grain in distal polar view, showing sharply defined sulcus and coarse reticulate mesh within the sacci; 148.36 mbsf. Fig. 58. Lygistepollenites sp. cf. L. balmei (Cookson) Stover \& Evans 1973; large bisaccate pollen grain in equatorial view, showing reticulate cappa and thickened rod-like muri within the sacci; 142.5 mbsf. Fig. 59. Dacrydiumites florinii Cookson \& Pike 1953; small bisaccate pollen grain in oblique distal polar view, showing incomplete (arcade-like) reticulate mesh within the sacci, which partially envelop the corpus; $170.98 \mathrm{mbsf}$ Scale bar $=25 \mu \mathrm{m}$.
} 

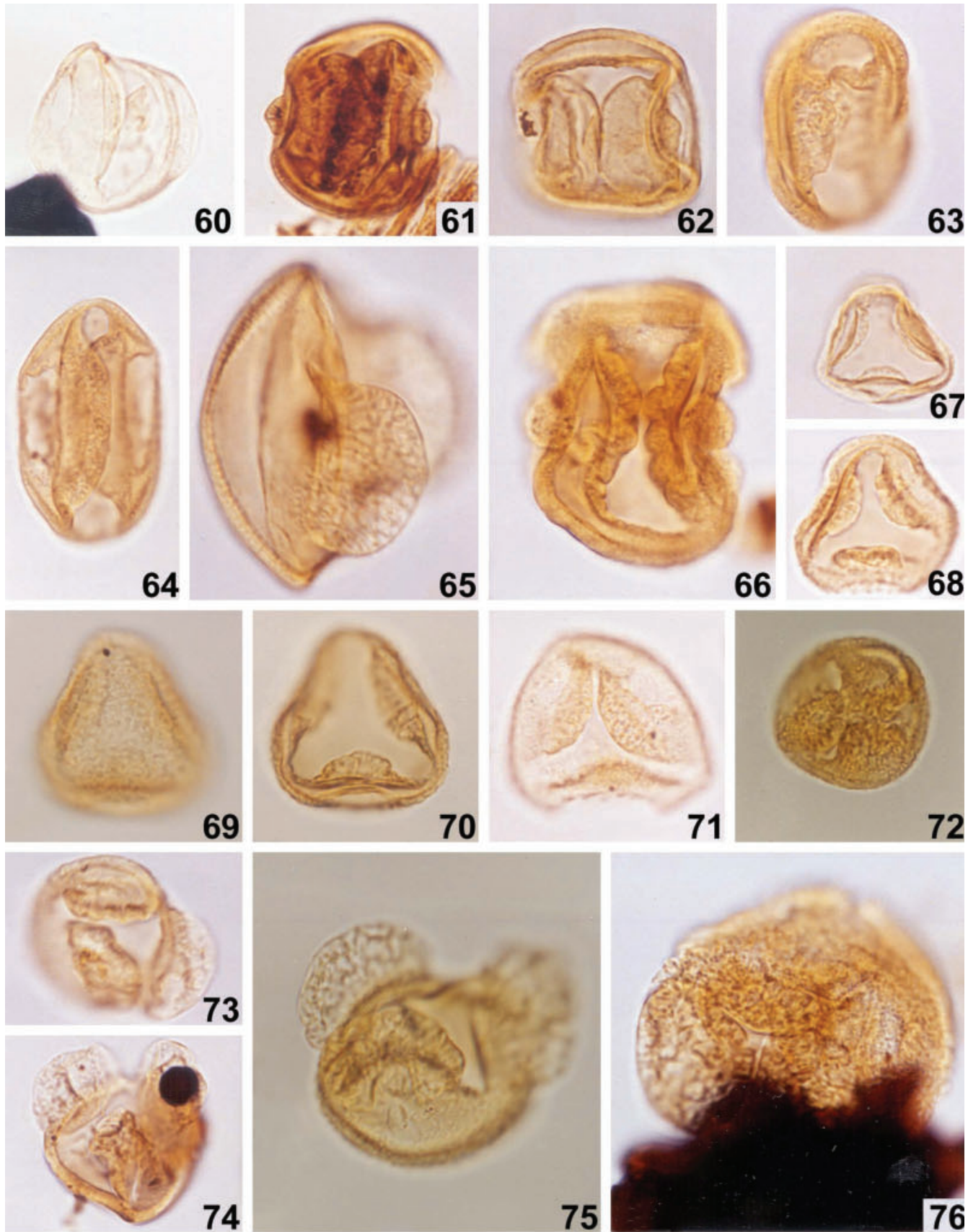

71

72
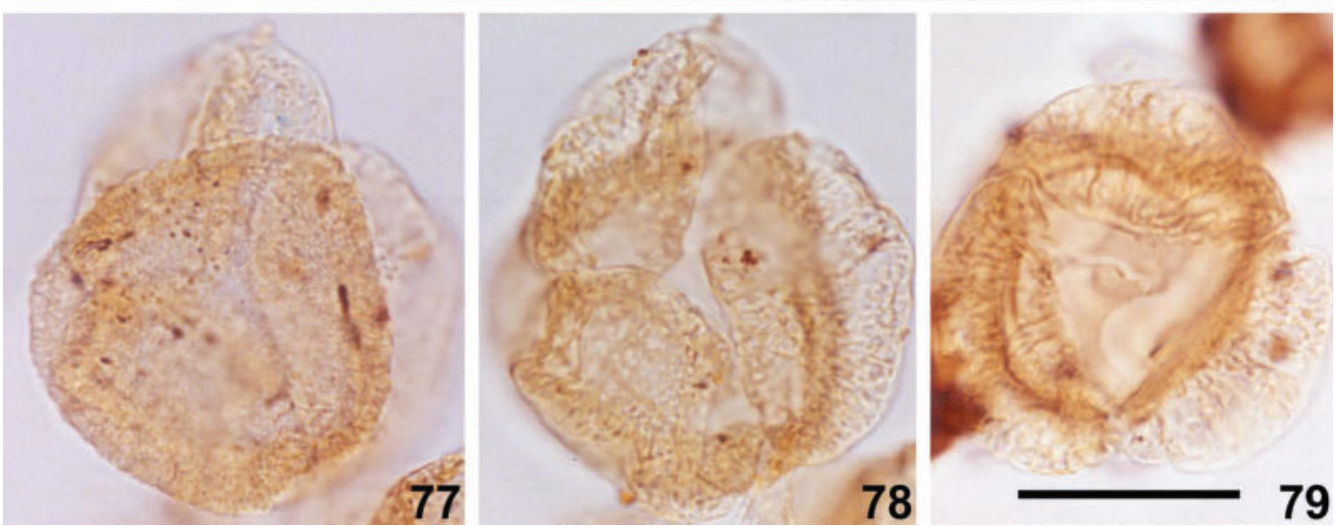
McMurdo erratics. M. palaeogenicus occurs as a recycled element in Ross Sea sediments (Truswell 1983) whereas 'Phyllocladus' was reported from the CIROS borehole in the same region (Mildenhall 1989). One Late Eocene sample from the South Tasman Rise (ODP Site 1171D) preserved 1\% of this pollen type. Living species such as Phyllocladus aspleniifolius (Tasmania) and $P$. alpina (New Zealand) range from lowland temperate rainforest into the upper subalpine or alpine zones.

Microcachryidites antarcticus Cookson 1947 (Figs 73-75). The species occurs in trace amounts in many of McMurdo erratic samples and in Oligo-Miocene glacimarine sediments in the Ross Sea. Larger specimens characterised by a thick cappa ornamented by coarse rugulae (Fig. 76) more closely resemble Podosporites variabilis Sukh Dev. 1961 (al. Microcachydites castellanosii Menendez 1968) and may be reworked from Jurassic-Early Cretaceous sequences. Nevertheless, variations in pollen morphology suggest that $M$. antarcticus sensu stricto, which first appears in southern Australia and other southern hemisphere continents during the Late Jurassic, encompasses several extinct ecotypes. For example, macrofossils confirm that an extinct ecotype of Microcachrys tetragona survived in lowland western Tasmania into the Early Pleistocene (Jordan 1995). The sole NLR (Microcachrys tetragona) is restricted to coniferous heath in the uppermost subalpine-alpine zone in Tasmania (Crowden 1999).

Phyllocladidites mawsonii Cookson ex Couper 1953 (Figs 61, 62). This bisaccate fossil species is distinguished by tubercles above the insertion point of the sacci. The species occurs in Eocene sequences at Site 696 in the northern sector of the Ross Sea (Mohr 1990) and also in low numbers in the McMurdo erratics and (recycled?) Miocene glacimarine sediments in the Ross Sea and up to $3 \%$ on some Late and Middle Eocene samples at ODP Sites 1170D and 1172A on the South Tasman Rise and East Tasman Plateau, respectively (M. K. Macphail, unpubl. data). Two closely related tuberculate pollen morphotypes found at Prydz Bay are P. verrucatus Stover \& Evans 1973, distinguished by verrucate ornamentation on the cappa (not illustrated), and $P$. reticulosaccatus Harris 1965, distinguished by reticulate strengthening tissues within the sacci (Figs 64, 65). The variant of $P$. mawsonii, illustrated in Fig. 66, is most commonly found in Paleocene sequences in south-eastern Australia (M. K. Macphail, pers. obs.), and it is possible that this specimen and grains of $P$. reticulosaccatus and $P$. verrucosus at Prydz Bay are reworked. The sole NLR of P. mawsonii, the Huon Pine Lagarostrobos franklinii, typically is an emergent tree in lowland cool-temperate rainforest lining river banks in western Tasmania, although it can occur as a krumholtz shrub in the upper subalpine zone (Read 1999).

Podocarpidites Cookson ex Couper 1953 (Figs 52-56). Bisaccate types assigned to this genus form the largest single taxon of fossil conifer pollen found in the Eocene at Prydz Bay and the same appears to be true for the Oligocene, on the basis of specimens recorded in the Ross Sea in the Early Oligocene (4 spp.) and Late Oligocene (5 spp.), reported by Prebble et al. (2006). Earlier studies, e.g. Couper (1960) and Romero (1977), used differences in grain size, the projection of and internal thickening within the sacci and sculptural patterns on the cappa to separate Podocarpidites into several more-or-less distinctive morphospecies. In the present study, we illustrate several of the morphotypes found at Prydz Bay although have not assigned these to fossil species for the following two reasons: (1) to do so may indicate a closer relationship between the podocarp floras of Prydz Bay and those of other landmasses than can be confirmed by the fossil evidence; and (2) Podocarpus sensu lato has been subdivided into several related genera, which may not be distinguishable, by using characters visible under the light microscope, from other genera within the Podocarpaceae, e.g. Acmopyle, Falcatifolium, Lepidothalmus, Prumnopitys and? Retrophyllum. Nevertheless, we note that the 'bald' sacci in the specimen illustrated in Fig. 52, and in fig. $3 d$ in Raine and Askin (2001), are similar to sacci in the Early-Middle Miocene New Zealand species Podocarpidites torquatus Mildenhall \& Pocknall 1989, although the specimen lacks the

Figs 60-79. Fig. 60. Microalatidites palaeogenicus (Cookson \& Pike) Mildenhall \& Pocknall 1989. Small bisaccate pollen in oblique distal polar view, grain showing reduced sacci; $156.99 \mathrm{~m}$ below the modern sea floor (mbsf). Figs 61, 62. Phyllocladidites mawsonii Cookson ex Couper 1953. Fig. 61. Bisaccate pollen grain in distal polar view, showing prominent columellate tubercules on the corpus; 180.4 mbsf. Fig. 62. Bisaccate pollen grain in distal polar view, showing weakly developed reticulate mesh within the sacci; 156.99 mbsf. Fig. 63. Phyllocladidites sp. cf. P. mawsonii Cookson ex Couper 1953; bisaccate pollen grain in distal polar view, showing incipient development of reticulate mesh within the sacci, tubercules absent; 142.5 mbsf. Figs 64, 65. P. reticulosaccatus Harris 1965. Fig. 64. Bisaccate pollen grain in distal polar view, showing fine reticulate mesh within the sacci, tubercules absent; $148.36 \mathrm{mbsf}$. Fig. 65. Bisaccate pollen grain in equatorial view, showing open reticulate mesh within the sacci, tubercules absent; $142.5 \mathrm{mbsf}$. Fig. 66. Variant of $P$. mawsonii Cookson ex Couper 1953; bisaccate pollen grain in distal polar view, showing prominent tubercules and reduced sacci; 156.99 mbsf. Fig. 67. Podosporites-Trichotomosulcites complex; trisaccate pollen grain in distal polar view, showing three vestigial sacci; 156.99 mbsf. Fig. 68. Podosporites-Trichotomosulcites complex; trisaccate pollen grain in polar view, showing three reduced sacci; 156.99 mbsf. Figs 69, 70. Podosporites-Trichotomosulcites complex. Fig. 69. Trisaccate pollen grain in proximal view, with weakly verrucate-rugulate cappa; $170.98 \mathrm{mbsf}$. Fig. 70. Same grain in distal polar view, showing three reduced sacci; $170.98 \mathrm{mbsf}$. Fig. 71. Podosporites-Trichotomosulcites complex; trisaccate pollen grain in distal polar view, showing well developed reticulate mesh within the sacci; 156.99 mbsf. Fig. 72. Podosporites-Trichotomosulcites complex; small trisaccate pollen grain, showing well developed reticulate mesh within the sacci; 156.99 mbsf. Figs 73-75. Microcachryidites antarcticus Cookson 1947. Fig. 73. Trisaccate pollen grain in distal polar view, showing inflated sacci supported by an internal fine reticulate mesh; $142.5 \mathrm{mbsf}$. Fig. 74. Trisaccate pollen grain in distal polar view, showing inflated sacci supported by an internal fine reticulate mesh; 142.5 mbsf. Fig. 75. Large trisaccate pollen grain in oblique equatorial view, showing finely scabrate cappa; 156.99 mbsf. Fig. 76. Podosporites variabilis Sukh Dev 1961; large trisaccate pollen grain in distal polar view, sacci obscuring rugulate cappa; 148.36 mbsf. Figs 77-79. Dacrycarpites australiensis Cookson \& Pike 1953. Fig. 77. Large trisaccate pollen grain in proximal polar view showing scabrate cappa; 148.36 mbsf. Fig. 78. Same pollen grain in distal polar view, showing open reticulate mesh within the large inflated sacci. Fig. 79. Large trisaccate pollen grain in polar view, showing the sulcus on the distal surface; $170.98 \mathrm{mbsf}$. Scale bar $=25 \mu \mathrm{m}$. 
coarsely rugulate cappa of the latter species. The large morphotype compared with Podocarpidites marwickii Couper 1960, which is illustrated in Fig. 56, and also in fig. $3 e, f$ in Raine and Askin (2001), is a persistent element in most Tertiary sequences in Australia. Podocarpus sensu stricto encompasses 93 species distributed across both hemispheres (Enright et al. 1995), including several that extend into coldclimate vegetation types, e.g. Podocarpus lawrencei in Tasmania and $P$. nivalis in New Zealand. Unlike the Araucariaceae, the abundance of Podocarpidites pollen remains relatively constant during the sampled interval, consistent with the taxon being tolerant of the progressive cooling in East Antarctica.

Podosporites-Trichotomosulcites complex (Figs 67-72). This extinct complex encompasses probable fossil relatives of Microcachrys tetragona, e.g. Trisaccites microsaccatus (Couper) Couper 1960, P. parvus Couper 1953 and Trichotomosulcites subgranulatus Couper 1953, and may include specimens that have been reworked from pre-Eocene deposits. The possible reworking of pollen grains in this category in the Cape Roberts sequences was also noted by Askin and Raine (2000) and Raine and Askin (2001). Only trace numbers of $T$. subgranulatus occur in the Oligo-Miocene glacimarine sediments (Prebble et al. 2006). Relative-abundance data indicate the parent conifer(s) almost certainly were shrubs growing in coniferous heath or around freshwater swamps at Prydz Bay (cf. Tulip et al.1982; Macphail et al. 1994; Macphail and Cantrill 2006).

\section{Anthophyta}

Angiosperms are not only the most diverse, but also for most samples, the most numerically abundant component in the Late Eocene sequence. This is partly due to the high relative abundance of fossil Nothofagus (Nothofagidites) species, (up to $60 \%$ of the total terrestrial count) and also because the actual diversity of the angiosperm flora is concealed by subtle morphological differences in this pollen group and also in Proteaceae (Proteacidites) pollen. A minimum of 17 extant families and five extinct clades of family or lower taxonomic rank are represented; however, this number may be much higher if differences in pollen morphology represent taxonomically distinct species or genera. Most of the formally defined fossil species are also likely to represent extinct genera even when the plant family can be identified with certainty with a living taxon.

\section{Monocotyledonae}

Arecaceae (Palmae)?

Arecipites spp. Wodehouse 1933 (Figs 80, 81). This form genus was erected to accommodate monosulcate pollen; however, subsequent emendations have narrowed the definition to palm-like pollen grains with a tapered sulcus and tectate exine that is punctate, finely foveolate or scrobiculate although not clearly reticulate under brightfield microscopy (see discussion in Kemp and Harris 1977; Mildenhall and Pocknall 1989). The Prydz Bay specimens referred to Arecipites are characterised by pointed apices, microreticulate? sculpture and overlapping sulcal margins that are typical of pollen produced by extant palm genera such as Rhopalostylis. However, the presence of palms in the Prydz Bay flora is considered to be intrinsically improbable because living genera mostly are restricted to warm temperate to tropical vegetation formations (although note the Nikau palm of New Zealand, which extends southwards to the Chatham Islands at $44^{\circ} \mathrm{S}$ ). Another (extinct) source for the Prydz Bay specimens is likely. For example, the specimen illustrated in Fig. 81 is not dissimilar to Mesozoic cycad or Gingko pollen (Cycadopites Wodehouse ex Wilson \& Webster 1946) (see Dettmann 1994; Sajjadi and Playford 2002b).

\section{Cyperaceae}

Cyperaceaepollis neogenicus Krutzsch 1970 (Fig. 82). The single grain recorded at $180 \mathrm{mbsf}$ shows the longitudinal ulceroid aperture diagnostic of this species and pollen produced by extant Cyperaceae genera such as Schoenus and Scirpus. The only other records from East Antarctica are

Figs 80-101. Figs 80, 81. Arecipites sp. Fig. 80. Psilate monosulcate pollen grain in distal polar view, showing the flared sulcus characteristic of modern Arecaceae pollen; $156.99 \mathrm{~m}$ below the modern sea floor (mbsf). Fig. 81. Psilate monosulcate pollen grain in distal polar view, showing the sulcus tapering towards the amb; 156.99 mbsf. Fig. 82. Cyperaceaepollis neogenicus Krutzsch 1970; compressed anisopolar pollen grain in equatorial view, characterised by longitudinally aligned ulceroid apertures (obscured); $180.4 \mathrm{mbsf}$. Fig. 83. Liliacidites sp. cf. L. bainii Stover \& Partridge 1973; puncto-reticulate monosulcate pollen in equatorial view; 170.98 mbsf. Fig. 84. Liliacidites sp.; open reticulate or crotonoid monosulcate pollen in oblique equatorial view; 142.5 mbsf. Fig. 85. Luminidites sp. cf. L. phormoides (Stover \& Partridge) Pocknall \& Mildenhall 1984; finely reticulate trichotomosulcate pollen grain in distal polar view; 180.4 mbsf. Fig. 86. Milfordia hypolaenoides Erdtman 1960; folded pollen grain in equatorial view, showing ulceroid aperture at pole; 142.5 mbsf. Figs 87, 88. Milfordia homeopunctata (McIntyre) Stover \& Partridge 1973. Fig. 87. Folded pollen grain in polar view, showing scattered scrobiculi and annulate pore; 142.5 mbsf. Fig. 88. Folded pollen grain in oblique polar view, showing scattered scrobiculi and annulate pore; 156.99 mbsf. Fig. 89. Poaceae; modern contaminant pollen grain in oblique equatorial view, showing annulate pore; 180.4 mbsf. Fig. 90. Australopollis obscurus. (Harris) Krutzsch 1966; finely reticulate periporate pollen grain, showing irregular to subcircular pores; $170.98 \mathrm{mbsf}$. Fig. 91. Periporopollenites polyoratus (Couper) Stover \& Partridge 1973; finely scabrate periporate pollen grain showing subcircular pores; 156.99 mbsf. Fig. 92. Periporopollenites sp. cf. P. vesicus Stover \& Partridge 1973; large punctoreticulate, periporate pollen grain showing well defined circular pores; $220.85 \mathrm{mbsf}$. Fig. 93. Ilexpollenites sp.; tricolporoidate pollen in equatorial view showing well developed clavae; 148.36 mbsf. Fig. 94. Haloragacidites harrisii (Couper) Harris 1971; triporate pollen grain in polar view; 170.98 mbsf. Figs 95-97. Tricolpites sp. cf. T. asperamarginis McIntyre 1968; tricolpate weakly scabrate pollen grains in polar view, with gaping apertures; all from 156.99 mbsf. Fig. 98. Fischeripollis sp. A of Truswell and Macphail 2004; very large and thick-walled acalymmate tetrad showing multicycloporate apertures and spinose ornamentation; 148.36 mbsf. Figs 99, 100. Fischeripollis sp. cf. sp. A of Truswell \& Macphail 2004. Fig. 99. Fragmented tetrad in surface optical section, showing spinose ornamentation; $142.5 \mathrm{mbsf}$. Fig. 100. Same tetrad in median optical section, showing multicycloporate apertures and spinose ornamentation. Fig. 101. Fischeripollis sp. A of Truswell and Macphail 2004; relatively small acalymmate tetrad showing multicycloporate apertures and spinose ornamentation; $148.36 \mathrm{mbsf}$. Scale bar $=25 \mu \mathrm{m}$. 

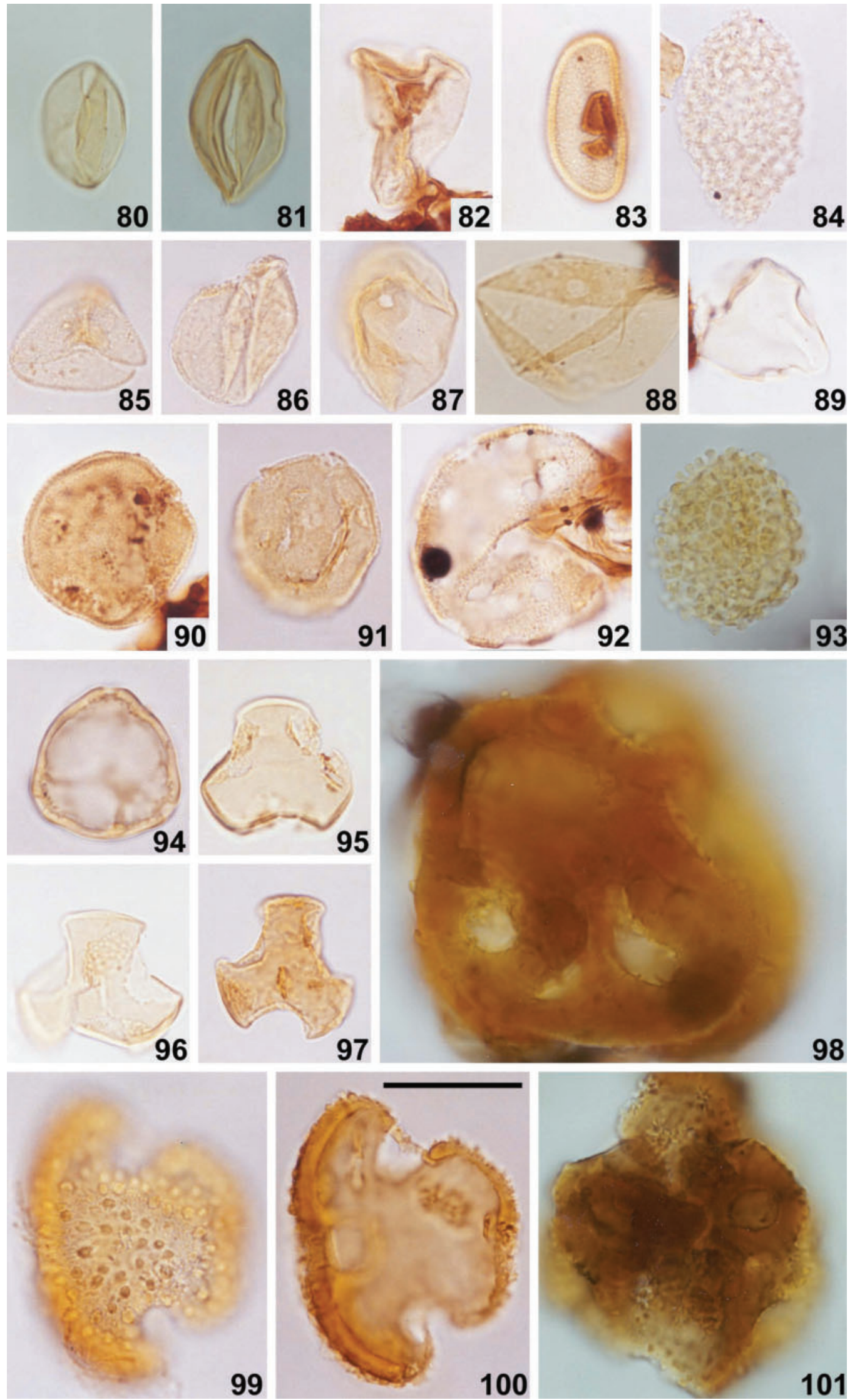

98 
Oligocene, from Cape Roberts Drillhole 2/2A (see Askin and Raine 2000). A single fruit attributed to the family has been described from the allegedly Pliocene Meyer Desert Formation of the Sirius Group in the Transantarctic Mountains (Ashworth and Cantrill 2004). C. neogenicus has been reported from Miocene deposits on Heard Island (Truswell et al. 2005). In Australia, the earliest occurrence of Cyperaceae-type pollen is in the Middle Eocene Murray Basin (see Truswell et al. 1985), although Gippsland Basin occurrences may be Early Eocene (M. K. Macphail, unpubl. data).

\section{Liliaceae sensu lato}

Liliacidites Couper 1953 (Figs 83, 84). Fossil reticulate monosulcate and trichotomosulate pollen types assigned to this form genus are represented by single specimens only at Prydz Bay. Finely reticulate Liliacidites morphospecies are usually compared to the late Early Eocene to late Early Miocene species L. bainii Stover \& Partridge 1973, although its resemblance to the specimen illustrated in Fig. 83 is not especially close. The morphotype broadly corresponds to pollen produced by the Liliaceae although an affinity with other monocot families is possible, e.g. Alliaceae and Arecaceae (see Mabberley 1997). One specimen (Fig. 84) at Prydz Bay has a crotonoid-like reticulum and thus differs from the wide-ranging New Zealand species L. variegatus Couper 1953.

\section{Liliaceae/Agavaceae}

The trichotomosulcate specimen illustrated in Fig. 85 is referred to Luminidites Pocknall \& Mildenhall 1984, although the reticulate ornamentation is much finer than that observed in the two described species in Australia and New Zealand, L. phormoides (Stover \& Partridge) Pocknall \& Mildenhall 1984 and P. reticulatus (Couper) Pocknall \& Mildenhall 1984. These two species have been compared to the pollen of the extant Phormium (Agavaceae) although the Prydz Bay specimen more closely resembles modern pollen produced by the Liliaceae genera Dianella (south-eastern Australia) and Pasithea (Chile). Morphotypes similar to that from Prydz Bay are known from the Miocene of Heard Island (Truswell et al. 2005) and the Miocene-Pliocene Forest Bed in the Falkland Islands (Macphail and Cantrill 2006).

\section{Restionaceae}

Milfordia Erdtman 1960 emend. Stover \& Partridge 1973 (Figs 86-88). Two scrobiculate morphotypes closely resembling pollen produced by graminoid and non-graminoid genera of Restionaceae occur in the upper part of the Prydz Bay sequence. These are Milfordia hypolaenoides Erdtman 1960, characterised by a single ulceroid aperture (Fig. 86), and Milfordia homeopunctata (McIntyre) Stover \& Partridge 1973, characterised by an annulate pore (Figs 87, 88). The latter species has been recovered from Recent muds in the Ross Sea (Truswell 1983). NLRs include Hypolaena, Hopkinsia and Lyginia, respectively (see Ladd 1977).

\section{Poaceae}

The specimen of Poaceae recorded at Prydz Bay (Fig. 89) is considered to be a modern contaminant. No specimens considered to be in situ were found.

\section{Dicotyledonae}

Aquilifoliaceae

Ilexpollenites Thiergart ex Potonie 1960 (Fig. 93). Fossil species assigned to this genus are highly variable in terms of the clavate ornamentation and development of the equatorial endopore (see discussion in Stover and Partridge 1973; Mildenhall and Pocknall 1989). For these reasons we have not assigned the fossil specimen recorded at Prydz Bay, which has a crotonoid sexine pattern, to any described species although its affinity to pollen produced by living Ilex (holly) is considered to be unequivocal. Ilexpollenites occurs in Campanian to Danian sediments in West Antarctica (Dettmann 1989; Askin $1990 a$ ) and as a reworked element in the Ross Sea (Warny et al. 2006). The Prydz Bay specimen appears to be the first record that the genus may have survived in East Antarctica into the Late Eocene time. The majority of living Ilex are tropical to cool temperate species and range in stature from trees and shrubs to epiphytes. One species (I. aquifolium) extends to high latitudes in north-western Europe; other species occur as prostrate or creeping forms in the subalpine flora of Yunnan, China (see Martin 1977).

\section{Callitrichaceae}

Australopollis obscurus (Harris) Krutzsch 1966 (Fig. 90). This fossil pollen type is considered to be an extinct member of Callitrichaceae, a family of obligate freshwater herbs (Macphail and Partridge 1991). An association with cool-cold (and winter-dark) conditions is supported by the first occurrence of the species in south-eastern Australia during the Late Campanian and its extinction during the Early Eocene (Partridge 1999). The Prydz Bay specimens indicate the genus survived in Antarctica into Late Eocene time.

\section{Caryophyllaceae}

Periporopollenites Pflug ex Thompson 1953 (Figs 91, 92). Two fossil species of Periporopollenites at Prydz Bay can be assigned to the extant family Caryophyllaceae with varying degrees of confidence. The first species, $P$. polyoratus (Couper) Stover \& Partridge 1973 (Fig. 91), has been recovered from in situ anthers of a fossil Caryophyllaceae flower preserved in Middle-Late Eocene sediments in Tasmania (Jordan and Macphail 2003). The second morphotype (Fig. 92), compared with P. vesicus Stover \& Partridge 1973, is much larger and characterised by nonannulate circular pores and may represent the same family. Raine (1998), Prebble et al. (2006) and Raine and Askin (2001) have recorded Caryophyllaceae pollen (as Caryophyllidites Couper 1960) in Oligo-Miocene sequences in the Ross Sea area. Mohr (1990) reported P. pallidus Truswell \& Owen 1988 from probable Late Eocene sediments in the Weddell Sea; however, the affinities of this form species are unknown. An unrelated Caryophyllaceae 
(Colobanthus) is one of the few living angiosperms present on the Antarctic continent. Most extant species are herbs although the family includes several shrub and smalltree genera.

\section{Casuarinaceae}

Haloragacidites harrisii (Couper) Harris 1971 (Fig. 94). Rare grains occur at Prydz Bay and were also reported in the McMurdo erratics (McIntyre and Wilson 1966; Askin 2000), in the Cape Roberts drillholes (as Myricipites harrisii (Couper) Dutta \& Sah 1970) by Raine and Askin (2001), and as recycled elements in Recent muds from the Ross Sea and Shackleton Ice Shelf areas (Truswell 1983). Other specimens have been reported from Paleocene sediments on Seymour Island (Baldoni and Barreda 1986; Askin 1988, 1997, 1992) and Eocene sequences from the Weddell Sea (Mohr 1990). Values recorded in Middle Eocene marine sediments on the South Tasman Rise range from trace to $12 \%$ (M. K. Macphail, unpubl. data). The NLR is usually considered to be Casuarinaceae although the morphotype is very similar to the pollen of Myrica (Myricaceae) as well as the northern hemisphere Betula (Betulaceae) and the related? Tertiary genus Momipites (see Nichols and Ott 2006). Casuarinaceae pollen grains are very widely dispersed by wind across the Pacific and, for this reason, trace numbers of fossil Casuarinaceae are not necessarily conclusive evidence that the Casuarinaceae (or Myricaceae) were growing in Antarctica.

\section{Droseraceae}

Fischeripollis Krutzsch 1970 (Figs 98-101). Two undescribed morphospecies occur in low to trace numbers at Prydz Bay. The larger of these, Fischeripollis sp. A Truswell \& Macphail 2004, is represented by complete and fragmented tetrads in the Late Eocene interval; fragments of a second, related? morphotype (Fischeripollis sp. cf. sp. A Truswell \& Macphail 2004) occur in the same unit. Droseraceae pollen recorded by Askin (1997) from Eocene to earliest Oligocene sequences on Seymour Island, Antarctic Peninsula, appears to differ from the Prydz Bay specimens in the arrangement of the germinal apertures.

Droseraceae (undifferentiated) was also reported from the Early Miocene in the recent ANDRILL project drilling in southern McMurdo Sound (Raine et al. 2008). Pollen tetrads, identical to Fischeripollis sp. A, occur in Oligo-Miocene sediments in south-eastern mainland Australia and Tasmania (Macphail et al. 1991, 1993; Macphail and Hill 1994). Detailed morphological analysis indicates Fischeripollis spp., including Fischeripollis sp. A, are more closely related to Dionea (venus fly trap), now endemic to the eastern coast of the United States, than to any other living genus within the Droseraceae (Truswell and Marchant 1986). The presence of carnivorous plants growing at polar latitudes accords with the presence of insects, and in this context we note that the remains of Coleoptera and Diptera have been recovered from probable Pliocene deposits in the Transantarctic Mountains (Ashworth and Kuschel 2003; Ashworth and Thompson 2003).

\section{Epacridaceae?}

Ericipites Wodehouse 1933 (Figs 102, 103). Small, thickwalled tetrads probably representing Ericales (Epacridaceae?) are present in the uppermost samples at Site 1166. All are referred to E. scabratus Harris 1965. Similar forms have been reported from the Eocene erratics of the Ross Sea (Askin 2000), and Askin (1997) reported E. scabratus from Eocene sequences on Seymour Island. An Ericipites species occurs also in Danian sequences from Seymour Island (Askin 1988).

\section{Escalloniaceae}

Quintiniapollis Mildenhall ex Pocknall 1989 (Figs 104, 105). A pentacolporoidate pollen grain with a faintly scabrate sculpture is referred to Quintiniapollis, a genus that was erected to accommodate pollen with affinities to Escalloniaceae (Mildenhall and Pocknall 1989). The Prydz Bay species differs from the only previously described species, Quintiniapollis psilatispora (Martin) Mildenhall \& Pocknall 1989, in being larger and thicker-walled. The NLR is Quintinia, a genus of small rainforest trees that is variously accommodated in the Escalloniaceae or Grossulariaceae.

\section{Euphorbiaceae}

Malvacipollis Harris 1965 (Figs 106-111). At least three spinose stephanoporate pollen types conforming to the description of this form genus (see Mildenhall and Pocknall 1989) occur in trace numbers at Prydz Bay. Specimens able to be assigned to formally described species are $M$. diversus Harris 1965 (Fig. 106) and M. subtilis Stover \& Partridge 1973 (Figs 107-109), found in Late Paleocene to Late Eocene and Danian to Pliocene sequences in south-eastern Australia, respectively. These morphospecies are part of a complex that also includes much larger and robustly ornamented spinose-echinate stephanoporate types (Figs 110, 111). The Prydz Bay records make it highly likely that the Malvacipollis flora in East Antarctica was as diverse as that growing in south-eastern Australia (cf. Macphail et al. 1994). Other specimens, assigned to $M$. diversus, $M$. sp. cf. diversus and Malvacipollis sp. cf. subtilis, are recorded from the Eocene of Seymour Island (Askin 1997), in the McMurdo erratics (Askin 2000), and in Recent samples from the Ross Sea (Truswell 1983; Warny et al. 2006). M. diversus and M. subtilis are similar to pollen produced by modern tropical south-western Pacific genera Austrobuxus and Dissiliaria (see Martin 1974, 1994). The specimens illustrated here lack the cushion-like bases to the echinae, and are thus unlikely to be derived from fossil representatives of the Malvaceae.

\section{Myrtaceae}

Myrtaceidites parvus Cookson \& Pike 1954 (Figs 112, 113). Small, thin-walled parasyncolporate grains corresponding to M. parvus occur in two samples at Site 1166. Myrtaceidites is rare although it has a wide geographic distribution in Antarctica, e.g. from Deep Sea Drilling Site 270 in the Ross Sea (Kemp 1975), and is consistently present as a recycled element in sediments from the Ross Sea, Shackleton and West Ice Shelf (Truswell 1983). We illustrate for 

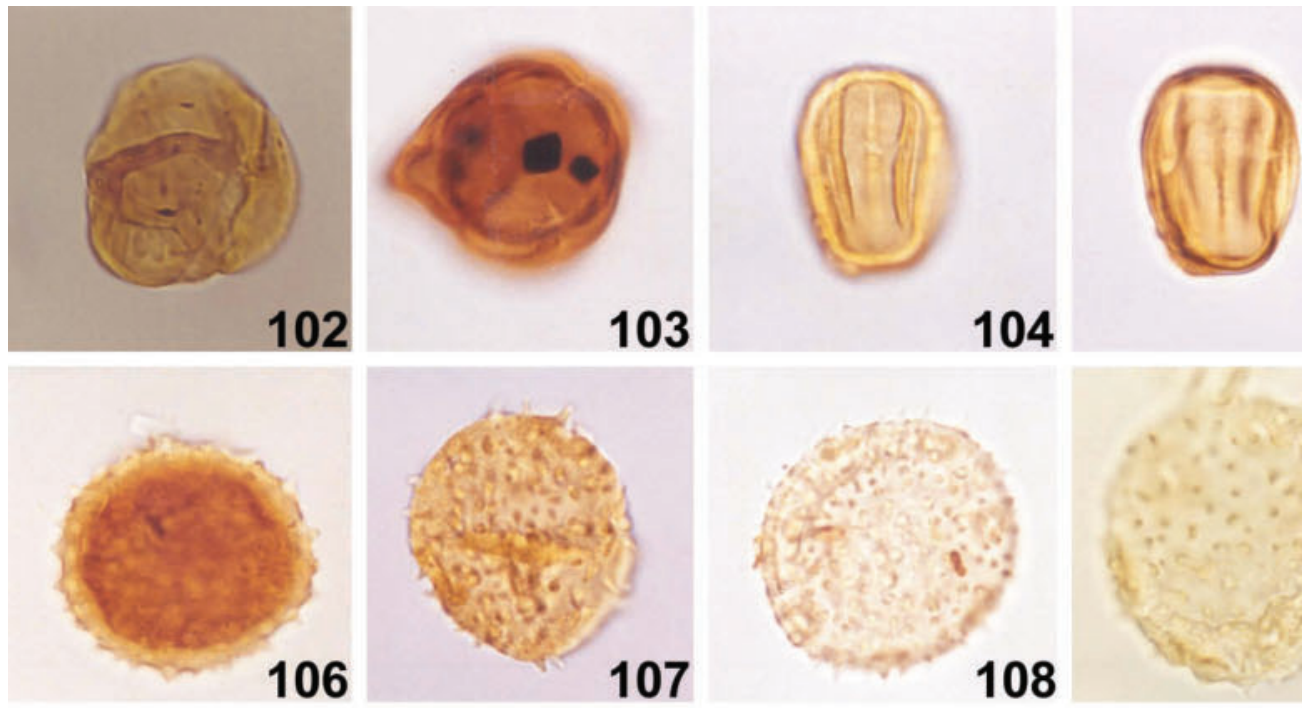

105
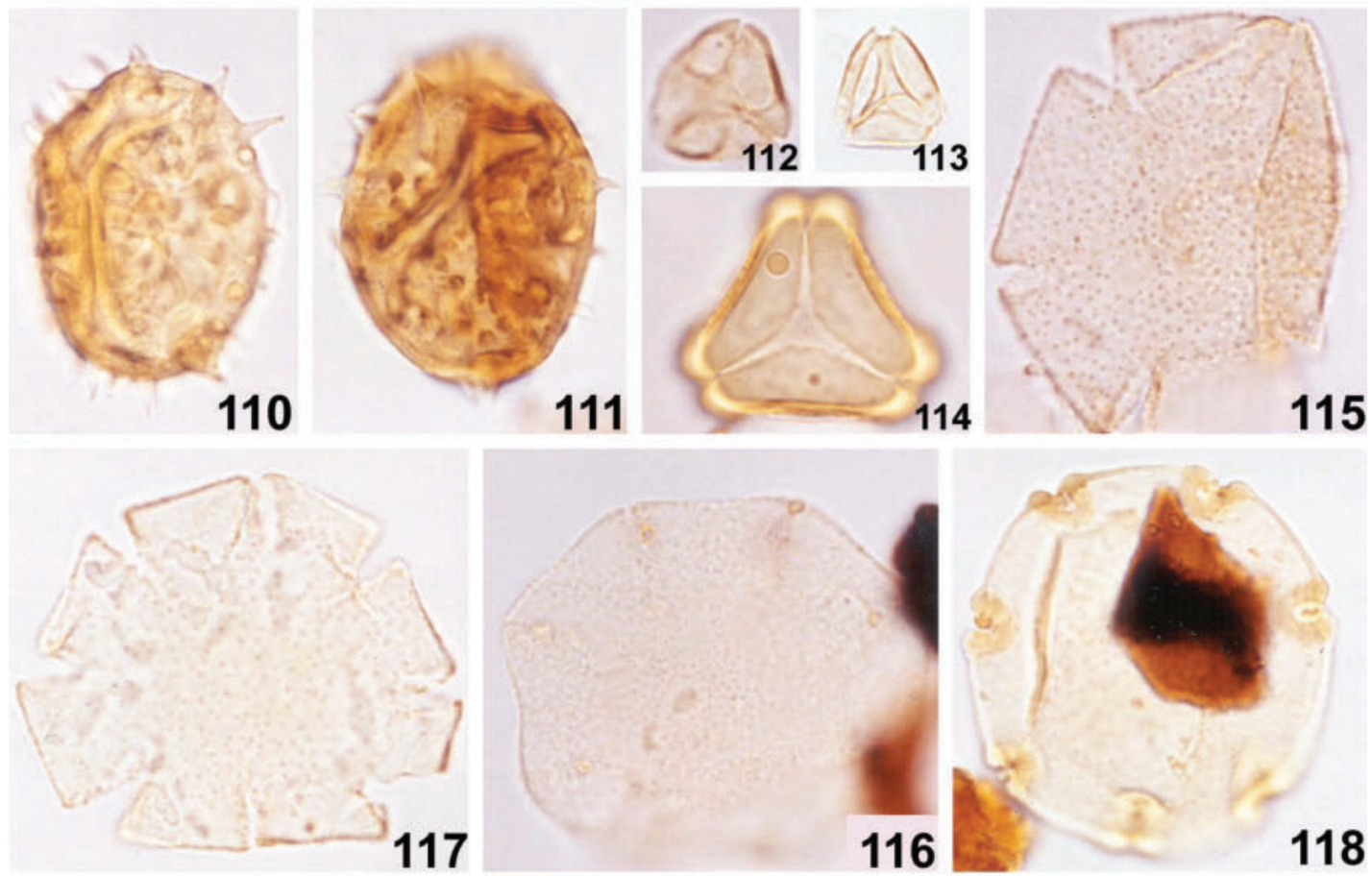

111
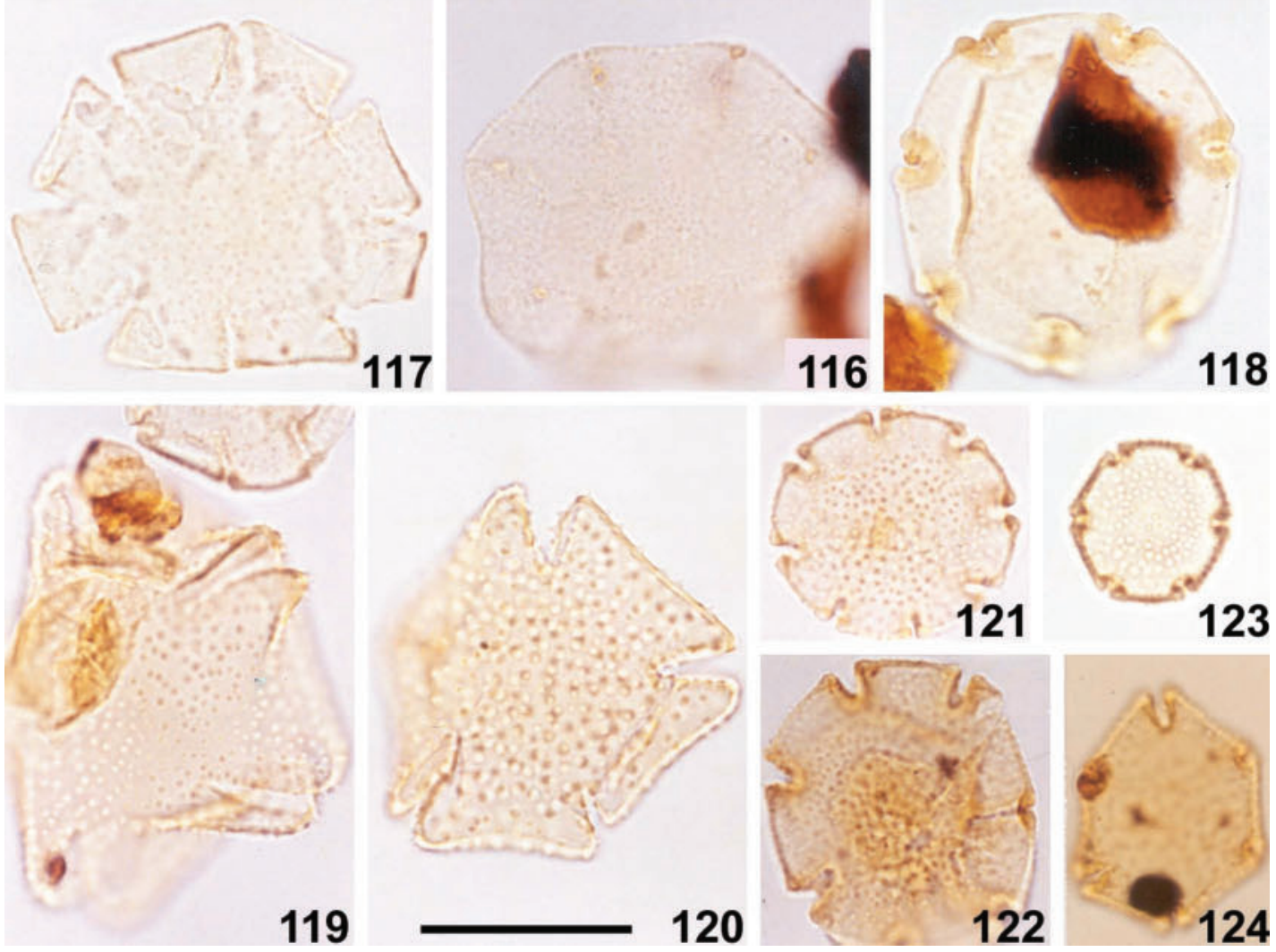
comparison modern Eucalyptus gummifera-type pollen recovered from $256.99 \mathrm{mbsf}$ (Fig. 114). This specimen, like some Casuarinaceae and all Poaceae pollen grains recorded in the Prydz Bay samples, is likely to be a modern contaminant, introduced into the sample from dust on the drilling rig or in the laboratory.

\section{Nothofagaceae}

Nothofagidites spp. Potonie 1960 (Figs 115-136). With the exception of N. goniatus (Cookson) Stover \& Evans 1973, fossil Nothofagus pollen have been assigned to species complexes centred around Australian fossil species typifying the following four living subgenera identified by Hill and Read (1991): Brassospora (Nothofagidites emarcidus complex), Fuscospora (Nothofagidites brachyspinulosus complex, Nothofagidites lachlaniae complex), Lophozonia (Nothofagidites asperus complex) and Nothofagus (Nothofagidites flemingii complex). It should be noted that the four extant subgenera are probably only the survivors of a much larger number of Tertiary subgenera (Hill 2001). We accept that equally valid species groupings could be made centred on species described in New Zealand or South America (see Dettmann et al. 1990).

Many specimens could not be assigned to individual species, suggesting that the parent plants were only distantly related to Nothofagus populations on adjacent landmasses and Hill (2001) proposed that some Brassospora morphotypes represent extinct taxa of subgeneric rank. Alternatively, cold climates in Antarctica arrested the development of some pollen grains, as almost certainly is the case in the Sirius Formation where macrofossils of one extinct species, Nothofagus beardmorensis Hill, Harwood \& Webb 1996 yielded pollen with and without thickened colpi (Hill and Truswell 1993; Hill et al. 1996; M. R. Bolick, X. Jiang and
D. M. Harwood, unpubl. data; M. K. Macphail, unpubl. data). A similar explanation (truncated morphogenesis owing to thermal stress) may underlie the high degree of variation observed in the Prydz Bay populations. However, not all the morphospecies and undescribed morphotypes recovered at Prydz Bay were recorded in the Ross Sea area by Raine (1998), Prebble et al. (2006) and Warny et al. (2006) and 'glacial winnowing' of the Nothofagaceae flora during the Eocene-Oligocene transition is a not an unreasonable explanation. The microfossil data are complemented by detailed analysis of Nothofagaceae macrofossils from East and West Antarctica (Birkenmajer and Zastawniak 1989; Hill 1991; Hill and Truswell 1993; Francis and Hill 1996).

Nothofagidites asperus complex (Figs 115-117). Specimens assigned to this complex broadly fall within the morphological spectrum accepted for $N$. asperus (Cookson) Stover \& Evans 1973 in Australia. We note that some variants, if found in South America, could be accommodated within $N$. americanus Zamaloa 1992, e.g. the specimen illustrated in Fig. 117, or N. tehuelchesii Zamaloa \& Barreda 1992. Living species within the subgenus Lophozonia range in size from tall canopy trees in lowland rainforest to krumholtz shrubs in the alpine heath, e.g. N. cunninghamii in Tasmania. Low relative-abundance values indicate the parent plants at Prydz Bay were either uncommon in the coastal vegetation or growing in the hinterland.

Nothofagidites brachyspinulosus complex (Figs 121-124, 134). Specimens assigned to this complex broadly fall within the morphological spectrum accepted for $N$. brachyspinulosus (Cookson) Harris 1965 (Figs 121-124) and (larger grains) N. incrassata (Cookson) Dettmann 1990. Morphotypes referred to one NLR, the New Zealand species Nothofagus fusca, make up $50 \%$ of assemblages in Late Oligocene microfloras recovered from the Cape Roberts drillholes in the Ross Sea area (Prebble et al. 2006). Living representatives of

Figs 102-124. Figs 102, 103. Ericipites sp. cf. E. scabratus Harris 1965. Fig. 102. Small acalymmate tetrad in oblique polar view, characterised by subdued scabrate ornamentation; $142.5 \mathrm{~m}$ below the modern sea floor (mbsf). Fig. 103. Small acalymmate tetrad in polar view, characterised by finely scabrate exine; 170.98 mbsf. Figs 104, 105. Quintiniapollis sp.; pentacolporoidate pollen grain in surface equatorial view, showing colporoid aperture; 156.99 mbsf. Fig. 105. Grain in median equatorial view, showing colporoid apertures. Fig. 106. Malvacipollis diversus Harris 1965; stephanoporate echinate pollen grain in which the bases of the closely spaced echini are wider than their height; 156.99 mbsf. Figs 107-109. M. subtilis Stover \& Partridge 1973 . Fig. 107. Stephanoporate echinate pollen grain in which the heights of the scattered echini are wider than their bases; 142.5 mbsf. Fig. 108. Stephanoporate echinate pollen grain, showing relatively closely spaced spines; 156.99 mbsf. Fig. 109. Stephanoporate echinate pollen grain, showing relatively widely spaced spines; 156.99 mbsf. Figs 110, 111. Malvacipollis sp.; large stephanoporate echinate pollen grain, showing annulate pores and long, widely spaced spines; $156.99 \mathrm{mbsf}$. Fig. 111. Large stephanoporate echinate pollen grain, showing annulate pores and relatively short, widely spaced spines; 170.98 mbsf. Figs 112, 113. Myrtaceidites parvus Cookson \& Pike 1954. Fig. 112. Pyrite-scarred parasyncolporate grain in oblique polar view; 142.5 mbsf. Fig. 113. Thin-walled parasyncolporate grain in polar view; 220.85 mbsf. Fig. 114. Eucalyptus gummifera-type; modern contaminant pollen grain in polar view; 256.99 mbsf. Figs 115, 116. Nothofagidites asperus (Cookson) Romero 1973. Fig. 115. Large, folded oblate pollen grain in polar view, showing convexly octagonal amb with uniformly scattered spinulae and gaping apertures with unthickened margins; 156.99 mbsf. Fig. 116. Large oblate pollen grain in polar view, showing poorly developed apertures; 156.99 mbsf. Fig. 117. Nothofagidites sp. cf. N. americanus Zamaloa 1992; large oblate pollen grain with straight sided amb in polar view; 156.99 mbsf. Fig. 118. N. flemingii (Couper) Potonie 1960; large oblate pollen grain in polar view, showing strongly thickened (collared) apertures and very small, widely spaced spinulae; 156.99 mbsf. Figs 119, 120. N. goniatus (Cookson) Stover \& Evans 1973. Fig. 119. Large oblate concavely pentagonal pollen grain in oblique polar view, showing narrow apertures with unthickened aperture margins; 156.99 mbsf. Fig. 120. Folded pollen grain in polar view, showing robust spinules, which extend along the aperture margins; 156.99 mbsf. Figs 121, 122. Nothofagidites sp. cf. $N$. incrassata (Cookson) Dettmann et al. 1990. Fig. 121. Relatively large oblate pollen grain with convexly octagonal sides, showing thickened 'U-shaped' margins to apertures and ornamented with relatively coarse spinulae; 156.99 mbsf. Fig. 122. Large oblate pollen grain, showing thickened 'U-shaped' margins to apertures and ornamented with coarse spinulae; 156.99 mbsf. Fig. 123. Nothofagidites sp. cf. brachyspinulosus (Cookson) Harris 1965; relatively small pollen grain, showing strongly thickened 'U-shaped' margins to apertures and ornamented with coarse spinulae; 156.99 mbsf. Fig. 124. Nothofagidites sp. aff. $N$. incrassata (Cookson) Dettmann et al. 1990; relatively small pollen characterised by irregular polygonal amb and strongly thickened ' $U$-shaped' margins to apertures; $156.99 \mathrm{mbsf}$. Scale bar $=25 \mu \mathrm{m}$. 

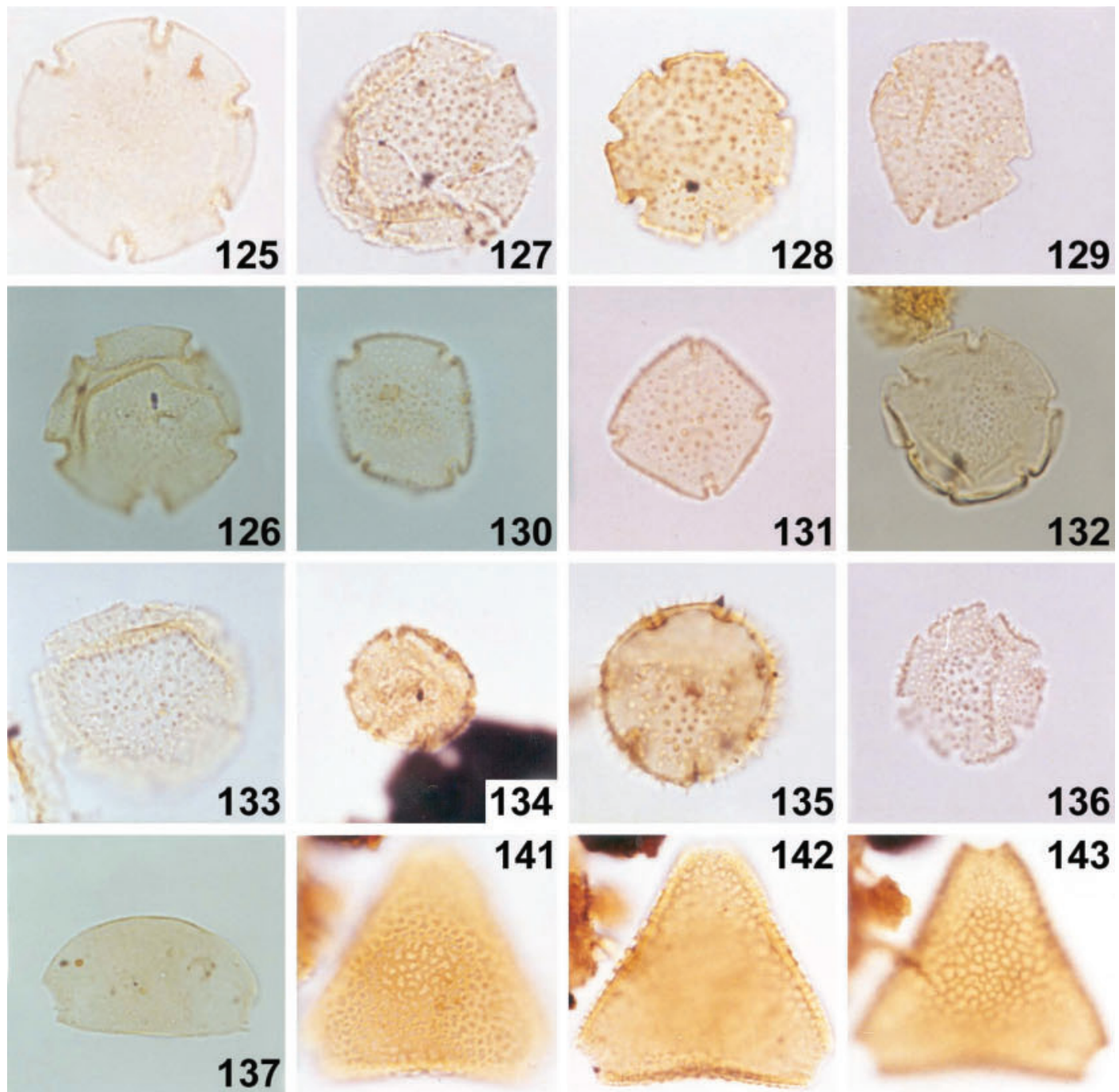

130
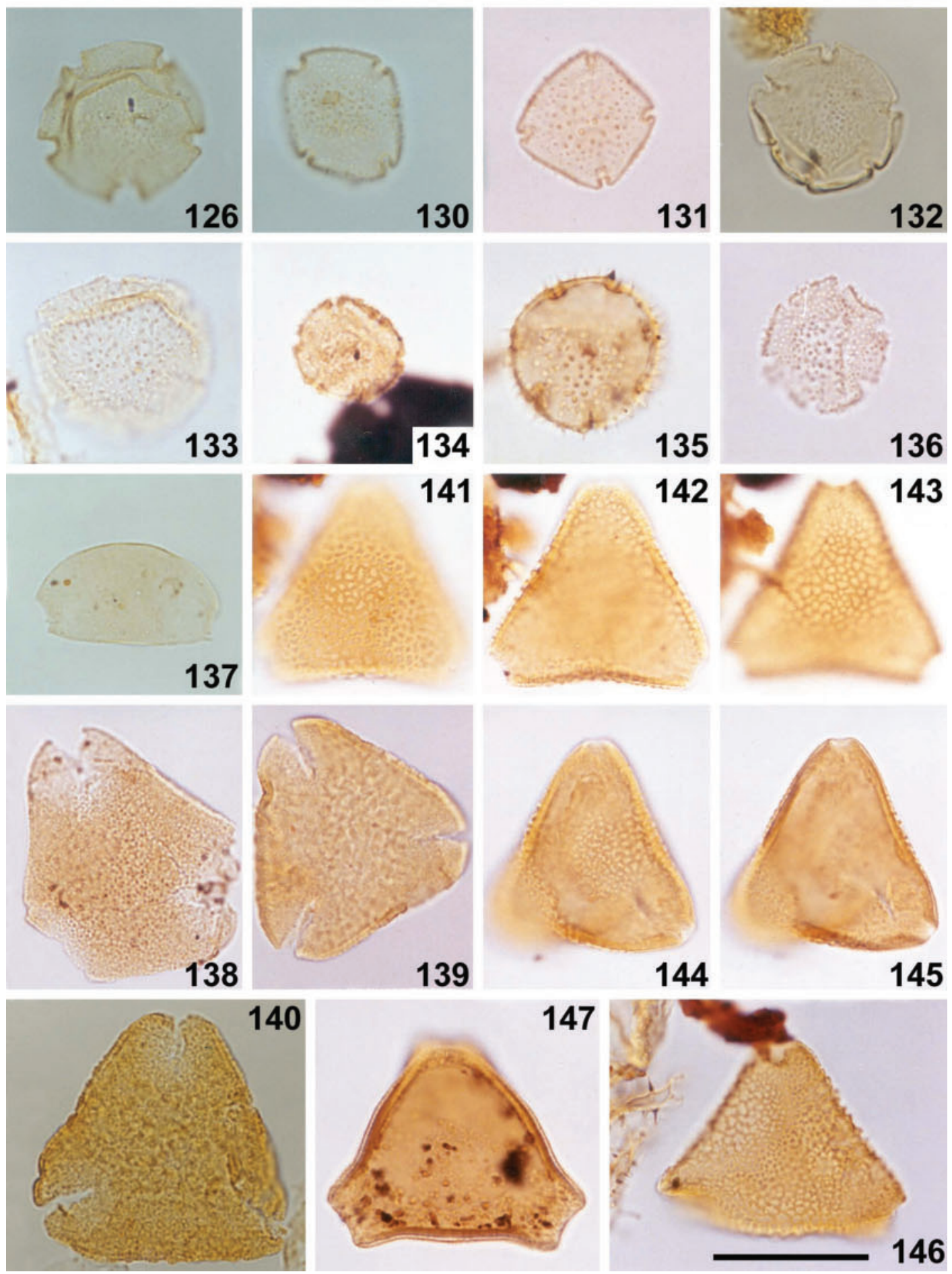

144
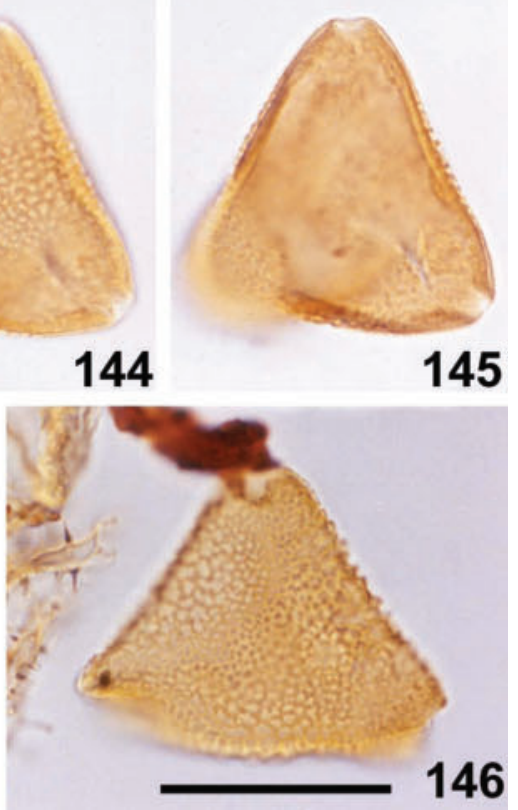
this complex range from tall trees in lowland rainforest, e.g. N. fusca and N. truncata in New Zealand, to deciduous krumholtz shrubs in the Tasmanian alpine zone, e.g. N. gunnii. Relative-abundance values appear to increase, then decline upsection during the probable Late Eocene interval. This is surprising because the pollen type is relatively common in Oligo-Miocene glacimarine sediments, and a Nothofagus leaf found in Oligocene marine sediments in the CIROS-1 Drillhole, Ross Sea, has been referred to N. gunnii (Hill 1989).

Nothofagidites spp. cf. N. emarcidus Harris 1965 complex (Figs 130, 131). This complex is used to accommodate small grains that lack colpal thickenings or diagnostic morphological characters found in other formally described morphospecies and, as such, are usually identified as fossil species of the subgenus Brassospora. Askin (2000) and Askin and Raine (2000) have identified the New Zealand fossil Brassospora species N. matauraensis (Couper) Hekel 1972 as well as unspecified 'Nothofagidites spp. (brassii group)' morphotypes in Eocene McMurdo erratics and Oligo-Miocene glacimarine sediments, respectively. None of the specimens observed at Prydz Bay conforms to the holotypes of $N$. emarcidus or $N$. matauraensis (cf. plate 3, figs 2-4 and plate 9, fig. 1 in Dettmann et al. 1990), although, if found in south-eastern Australia, the specimens illustrated in Figs 130, 131 would be lumped into $N$. emarcidus-heterus (Cookson) Stover \& Evans 1973. We suggest that these and other specimens assigned to the complex in the present study may be immature pollen grains of other species, e.g. N. lachlaniae (Couper) Pocknall \& Mildenhall 1984. If correct, then, in contrast to the Middle-Late Eocene vegetation in Australia and New Zealand, the fossil species belonging to the most commonly found subgenus of Nothofagus (Brassospora) on these landmasses were rare or absent in Antarctica.

Nothofagidites goniatus (Cookson) Stover \& Evans 1973 (Figs 119, 120). This distinctive large morphotype has been referred to the subgenus Lophozonia (preferred) or subgenus Brassospora, depending on whether greater weight is given to its size and concave-pentagonal amb, or to slight thickening of the colpal margins (see discussion in Dettmann et al. 1990). The species is mostly rare in south-eastern Australia, although, as at Prydz Bay, may be frequent in occasional samples.

Nothofagidites flemingii complex (Fig. 118). Specimens assigned to this complex broadly fall within the morphological spectrum accepted for N. flemingii (Couper) Potonie 1963 in Australia. The species is widely recorded in the McMurdo erratics and is occasionally 'abundant' in Oligo-Miocene samples from the Ross Sea. Despite the very low yields, the morphospecies is almost twice as common as $N$. lachlaniae (see below) in the Late Oligocene microfloras recovered from the Cape Roberts drillholes (Prebble et al. 2006). We note that some variants of $N$. flemingii, if found in South America, could be accommodated within $N$. rocaensis Romero 1973 or N. saraensis Menendez \& Caccavari 1975. Nothofagus (Nothofagus) spp. are endemic to South America where life

Figs 125-147. Figs 125-129. Nothofagidites lachlaniae (Couper) Pocknall \& Mildenhall 1984. Fig. 125. Large oblate pollen grain in polar view, showing convexly hexagonal amb with weakly thickened (U-shaped) margins to the apertures and ornamented with granule-like small spinules; $156.99 \mathrm{mbelow}$ the modern sea floor (mbsf). Fig. 126. Relatively small oblate pollen grain in polar view, showing convexly hexagonal amb with weakly thickened (U-shaped) margins to the apertures and ornamented with small spinules; $142.5 \mathrm{mbsf}$. Fig. 127. Relatively large oblate pollen grain in polar view, showing convexly hexagonal amb with weakly thickened (U-shaped) margins to the apertures and ornamented with coarse spinules; $142.5 \mathrm{mbsf}$. Figs 128, 129. Nothofagidites sp. cf. N. lachlaniae (Couper) Pocknall \& Mildenhall 1984. Fig. 128. Relatively small oblate pollen grain in polar view, showing convexly hexagonal amb with thickened (U-shaped) margins to the apertures and ornamented with coarse spinules; $142.5 \mathrm{mbsf}$. Fig. 129. Relatively small oblate pollen grain in polar view, showing irregular convexly hexagonal amb with unthickened aperture margins and ornamented with fine to coarse spinules; $142.5 \mathrm{mbsf}$. Figs 130, 131. Nothofagidites sp. cf. $N$. emarcidus (Cookson) Harris 1965. Fig. 130. Relatively small pollen grain in polar view, showing convexly quadrangular amb with weakly thickened (U-shaped) margins to the apertures and ornamented with fine to coarse spinules; $142.5 \mathrm{mbsf}$. Fig. 131. Relatively small pollen grain in polar view, showing convexly quadrangular amb with weakly thickened (U-shaped) margins to the apertures and ornamented with fine to coarse spinules; 156.99 mbsf. Fig. 132. Nothofagidites sp. cf. N. lachlaniae (Couper) Pocknall \& Mildenhall 1984; relatively small pollen grain in polar view, showing convexly hexagonal amb with weakly thickened (U-shaped) margins to the apertures and ornamented with fine spinules; 142.5 mbsf. Fig. 133. Nothofagidites sp. cf. N. nanus Romero 1977; relatively small pollen grain in polar view, showing convexly hexagonal amb with unthickened margins to the apertures and ornamented with evenly spaced, sharp spinules; $142.5 \mathrm{mbsf}$. Fig. 134. Nothofagidites sp. cf. $N$. brachyspinulosus (Cookson) Harris 1965; small pollen characterised by convexly hexagonal amb and very strongly thickened 'U-shaped' margins to apertures; 180.4 mbsf. Fig. 135. Nothofagidites sp. aff. N. spinosus (Couper) Mildenhall \& Pocknall 1989; relatively small pollen characterised by convexly pentagonal amb, very strongly thickened 'U-shaped' margins to apertures and ornamented with evenly spaced apiculae; 170.98 mbsf. Fig. 136. Nothofagidites sp. cf. N. deminutus-vansteenisii (Cookson) Stover \& Evans 1973; small oblate pollen grain characterised by convexly hexagonal amb, unthickened margins to the apertures and ornamented by closely spaced spinules; 156.99 mbsf. Fig. 137. Banksieaeidites/Granodiporites sp.; small diporate pollen grain that could be either poorly preserved B. arcuatus Stover \& Partridge 1973 or Granodiporites nebulosus Stover \& Partridge 1973; 156.99 mbsf. Fig. 138. Beaupreaidites elegansiformis Cookson 1950; tricolpoid oblate pollen grain in polar view showing marked thinning (and splitting) of the nexine around the apertures, and puncto-reticulate sculpture; 180.4 mbsf. Figs 139, 140. Beaupreaidites sp. cf. B. verrucosus Cookson 1950. Fig. 139. Tricolpoid oblate pollen grain, characterised by weakly developed, irregular shaped verrucae across the polar regions (apocolpia) and puncto-reticulate sculpture around the apertures; $142.5 \mathrm{mbsf}$. Fig. 140. Tricolpoid oblate pollen grain, characterised by weakly developed, irregular shaped verrucae across the polar regions and punctoreticulate sculpture around the apertures; 142.5 mbsf. Figs 141-143. Proteacidites kopiensis Harris 1972. Fig. 141. Triporate reticulate pollen grain in top surface polar view, showing increase in the size of the lumina towards the amb (mesocolpia); $170.98 \mathrm{mbsf}$. Fig. 142. Grain in median polar view, showing slight thickening of the exine in the mesocolpial region. Fig. 143. Grain in bottom surface polar view, showing increase in the size of the lumina towards the amb. Figs 144, 145. Proteacidites sp. cf. P. kopiensis Harris 1972. Fig. 144. Triporate reticulate pollen grain in oblique surface polar view, showing increase in the size of the lumina towards the amb; 170.98 mbsf. Fig. 145. Grain in median polar view, showing slight thickening of the exine in the mesocolpial region. Fig. 146. Proteacidites kopiensis Harris 1972; triporate reticulate pollen grain in top surface polar view, showing very marked increase in the size of the lumina from the apocolpial to mesocolpial regions; $142.5 \mathrm{mbsf}$. Fig. 147. P. angulatus Stover \& Partridge 1973; triporate puncto-reticulate pollen grain in median polar view, showing characteristic triangular shape and protruding apices; $170.98 \mathrm{mbsf}$. Scale bar $=25 \mu \mathrm{m}$. 
forms include deciduous ( $N$. antarctica, N. pumilio) and evergreen ( $N$. betuloides, $N$. dombeyi, $N$. nitida) species, range in size from low shrubs to tall trees, and occupy warm and wet to cold and xeric habitats (see Veblen et al. 1996).

Nothofagidites lachlaniae complex (Figs 125-129, 132). This complex accommodates specimens that broadly conform to the definition of $N$. lachlaniae (Couper) Pocknall \& Mildenhall 1984, although we note that size, shape and ornamentation are variable (cf. Figs 125, 128, 129). With the exception of the microflora at $210.18 \mathrm{mbsf}$, specimens assigned to this complex are the single most common fossil Nothofagus morphospecies recorded in the Late Eocene section at Prydz Bay. N. lachlaniae is present in almost all of the McMurdo erratics (Askin 2000) and in the Oligo-Miocene sequences in the Ross Sea, although relative abundances are lower than in the Early Oligocene (Prebble et al. 2006). It is the form species recovered in association with macrofossils, including Nothofagus beardmorensis, in the Meyer Desert Formation of the Sirius Group in the Transantarctic Mountains (Hill and Truswell 1993).

Nothofagidites sp. cf. N. nanus Romero 1977 (Fig. 133). Occasional pollen grains at Prydz Bay are ornamented with 'prickle-like' spinulae that are more characteristic of South American than Australian or New Zealand 'Brassospora' morphospecies (see Dettmann et al. 1990). The specimen illustrated in Fig. 133 closely resembles $N$. nanus, and if the identification is confirmed, represents the first occurrence of a South American Nothofagus species in East Antarctica, other than those belonging to the subgenus Nothofagus.

Nothofagidites sp. aff. N. spinosus (Couper) Mildenhall \& Pocknall 1989 (Fig. 135). The illustrated specimen is similar to $N$. spinosus in possessing unusually long and erect spines and differs from $N$. spinosus in that the colpal margins are strongly thickened as in the species of $N$. brachyspinulosus complex. The morphotype represents an undescribed fossil species, if not subgenus of Nothofagus.

Nothofagidites sp. cf. N. deminutus-vansteenisii (Cookson) Stover \& Evans (Fig. 136). Pollen grains ornamented with closely spaced 'squat' coni are similar to the spectrum of morphotypes categorised as $N$. deminutus-vansteenisii by Stover and Evans 1973 although they may differ in other characters. For example, the morphotype illustrated in Fig. 136 is characterised by gaping colpi. More convincing specimens of this morphospecies have been recorded from the western Ross Sea (see plate 8, figs 14, 15, 19-21 in Warny et al. 2006).

\section{Proteaceae}

Triporate grains identified as fossil Proteaceae pollen and accommodated in the form genus Proteacidites Cookson ex Couper 1953 are the single most common and diverse morphotype in Tertiary assemblages in southern Australia after conifers and Nothofagidites. The same appears to be true for Late Eocene Antarctica, where at least 28 triporate morphotypes are present within the Prydz Bay sequence. Most of these are morphologically simple types that may occur elsewhere; however, they are unlikely to have been formally described or had their time distributions documented systematically.
Dettmann and Jarzen (1996) attempted a segregation of triporate pollen by using the characteristics of the exine layers in the vicinity of the pores. Such a categorisation is not easy to apply and the morphological groupings do not appear to be unique to a particular subfamily within the Proteaceae (see fig. 5 in Dettmann and Jarzen 1996). In the present paper, we have applied Dettmann and Jarzen's (1996) form genera, although we do so with reservations. For example, Proteacidites Cookson ex Couper emend Dettmann \& Jarzen 1996 is used to accommodate morphotypes where the pore margins are formed by thinning (and often incurving) of both exine layers, whereas Propylipollis Martin \& Harris 1974 provisionally is used to accommodate morphotypes where the exine has been modified, usually by thickening, around the pore margins.

Beaupreaidites elegansiformis/Beaupreaidites sp. cf. B. verrucosus Cookson 1950 (Figs 138-140). Milne (1998) re-examined the type material of Cookson's species $B$. elegansiformis and determined that the material, from three different localities, could represent three different biological species. She designated one of these (Cookson 1950, plate 1, fig. 2) as the neotype for B. elegansiformis. The specimens reported here from the Prydz Bay sequence appear to conform to the morphology of the neotype. Milne (ibid) further noted a range of morphological variation within specimens assigned to B. elegansiformis from the (Late Eocene) type locality at Bacchus Marsh in Victoria. Within this morphological range, the Antarctic specimens range from morphotypes with a puncto-reticulate sculpture (Fig. 138) to those that fall into Milne's 'heavily sculptured' category. The latter (Figs 139, 140) are distinguished by the presence of raised, irregular thickenings over much of the grain surface, which tend to merge into each other rather than form discrete verrucae. These specimens intergrade with $B$. verrucosus Cookson 1950. Beaupreaidites spp. are uncommon although persistent in Tertiary assemblages in Australia, whereas in East Antarctica they have been recorded only as a recycled element in Recent sediments from the Ross Sea (Truswell 1983). In West Antarctica, specimens of B. elegansiformis have been recorded in Late Cretaceous sequences on James Ross and Seymour Islands (Askin 1989, 1990a; Baldoni 1992), and in the Late Eocene sequences in the Weddell Sea (Mohr 1990); B. verrucosus occurs in the Eocene of Seymour Island (Askin 1997). The NLR of B. elegansiformis is Beauprea (subfamily Conospermeae), in particular B. spathulaefolia, which is now confined to soils on ultramafic rocks in New Caledonia. Milne (1998) commented on the wide range of pollen morphology demonstrated by pollen obtained from the anthers of living taxa.

Banksieaeidites/Granodiporites sp. (Fig. 137). A poorly preserved diporate pollen grain, which could be either B. arcuatus Stover \& Partridge 1973 or a very small specimen of G. nebulosus Stover \& Partridge 1973, was recorded at 156.99 mbsf. Diporate morphotypes identified as Granodiporites sp. Varma \& Rawat 1963 also occur in the Eocene of the Antarctic Peninsula (Askin 1997) and may represent Embothrium. Banksieaeidites (NLRs Banksia, Dryandra) is present in Maastrichtian to Eocene deposits in the same region (see Askin and Baldoni 1998). 
cf. Cranwellipollis apiculatus (Stover \& Partridge) Dettmann \& Jarzen 1996 (Fig. 170). The Prydz Bay specimen is distinguished by medium fine spinules that tend to cluster about the pores. Some nexinal breakdown is evident in the pore region. Modern Proteaceae pollen with similar spinulose ornamentation include Persoonia and Oreocallis. Dettmann and Jarzen (1996) proposed that the aperture morphology in C. apiculatus is similar to that found in subfamilies Proteoideae and Persooniodeae. The affinity of a second spinose triporate grain (Figs 236, 237) is obscure, and we have cited these specimens as cf. Cranwellipollis spiniferus (McIntyre) Martin \& Harris 1974.

Proteacidites angulatus Stover \& Partridge 1973 (Fig. 147). The specimen recovered from $170.98 \mathrm{mbsf}$ closely matches the holotype (cf. plate 22, figs 5, 6 in Stover and Partridge 1973) and is one of the very few triporate morphotypes found at Prydz Bay that can confidently be assigned to an Australian form species. The species does not appear to have been reported previously from Antarctica. Because $P$. angulatus last occurs in south-eastern Australia in the Early Thanetian (Partridge 1999), the Prydz Bay specimen is either recycled or represents a significant extension of its range. The modern affinity is probably with the subfamily Grevillioideae.

Proteacidites sp. cf. P. adenanthoides Cookson 1950 (Fig. 162). Morphotypes compared to this species are concave in polar view, with a puncto-reticulate exine that thins towards the pores. P. adenanthoides is more strongly lobate and closely resembles pollen of Adenanthos barbigera Lindl. (subfamily Proteoideae), although differences between the fossil and extant pollen are present (see Dettmann and Jarzen 1996).

Proteacidites crassimarginis Dudgeon 1983 (Fig. 164). Small, puncto-reticulate morphotypes with clearly developed nexinal thickenings around the pores are assigned to $P$. crassimarginis, a species first described from probable Middle Eocene deposits in the Yaamba Basin, Queensland (Dudgeon 1983).

Proteacidites sp. cf. P. differentipolus Dudgeon 1983 (Figs 167, 168). The illustrated specimen resembles $P$. differentipolus in that both morphotypes are characterised by reticulate sculpture in which the size of the lumina varies markedly on opposite poles (up to $2.5 \mu \mathrm{m}$ on the polar surface illustrated in Fig. 167). The Prydz Bay specimen, however, is larger $(55 \mu \mathrm{m})$, has muri supported by single rows of columellae, and nexine that is thicker $(1.0-1.5 \mu \mathrm{m})$ than the sexine. Both wall layers diminish in thickness towards the pores. No comparable specimens appear to have been figured previously from Antarctic Tertiary sediments and its modern affinity within the Proteaceae is unknown.

Proteacidites kopiensis Harris 1972 (Figs 141-143, 146). This species is distinguished by the marked increase in the size of the lumina towards the mesocolpia. P. kopiensis has previously been reported as a recycled element in the Ross Sea region (Truswell 1983).

Proteacidites sp. cf. P. kopiensis Harris 1972 (Figs 144, 145, 182). This distinctive morphotype, found in samples within the Late Eocene sequence at Prydz Bay, is distinguished by its concave amb and pores with a diameter of $1.5-2.0 \mu \mathrm{m}$. The exine is stratified with clearly defined columellae and a nexine layer that is slightly thicker than the sexine. No exinous thickenings, or breakdown, can be seen around the pores. The surface reticulum coarsens markedly across the poles (Fig. 144) and mesocolpial regions where the lumina may be up to $1.5 \mu \mathrm{m}$ in maximum diameter. This morphotype, previously identified as $P$. kopiensis (plate 6 , figs 12,13 in Macphail and Truswell 2004a), differs from the latter species in having a concave amb and narrower pores, and in these respects, is closer to some of the illustrated specimens from the Eocene Yaamba Basin, Queensland (cf. fig. 19C, D in Dudgeon 1983). Pollen of some extant species of Gevuina (tribe Grevilleoidae) are superficially similar except that they show internal thickening in the pore region and a more regular reticulate sculpture (Dettmann and Jarzen 1998).

Proteacidites sp. cf. P. nitidus Dudgeon 1983 (Fig. 159). Morphotypes compared to this species are distinguished by a fine, evenly reticulate surface ornamentation, and a marked thickening of the nexine about the pores.

Proteacidites pseudomoides Stover \& Partridge 1973 (Fig. 156). Specimens identified from Prydz Bay closely resemble $P$. pseudomoides found in Early Eocene to Early Oligocene sequences in the Gippsland Basin (Stover and Partridge 1973), except that the columellae are more distinctly defined. The parent plant(s) appear to have been widespread around Antarctica during the Eocene because basically similar morphotypes assigned to $P$. pseudomoides have been recorded in the McMurdo erratics (Askin 2000), from Deep Sea Drilling Site 270 (Kemp 1975), as recycled elements in Recent muds in the Ross Sea (Truswell 1983) and in Eocene sequences in the Weddell Sea (Mohr 1990). Dettmann and Jarzen (1991) and Martin (1995) proposed that $P$. pseudomoides resembles pollen produced by Carnarvonia (tribe Carnarvonioideae). Askin and Baldoni (1998) followed Martin (1982) and considered the affinity remains speculative because of the 'generalised and primitive' nature of the pollen type.

Proteacidites sp. cf. P. reflexus Stover \& Partridge 1973 (Fig. 163). The illustrated morphotype differs from specimens of $P$. reflexus recovered from Middle to Late Eocene sequences in the Gippsland Basin in that the diagnostic thickening of the exine in the mesocolpia is much less pronounced (cf. plate 24, fig. 6 in Stover and Partridge 1973).

Proteacidites sp. cf. P. retiformis Couper 1960 (Fig. 166). The thin bimodal lumina and sieve-like appearance of the reticulum in the illustrated specimen are similar to $P$. retiformis, although the lumina do not decrease in size towards the pole to the same degree (cf. plate 6, figs 6, 7 in Couper 1960). Dettmann and Jarzen (1988) recorded P. retiformis in Campanian sequences on James Ross Island.

Proteacidites sp. cf. P. simplex Dudgeon 1983 (Fig. 149). Proteacidites simplex was erected to accommodate small (average $23 \mu \mathrm{m}$ ) triporate pollen with a fine puncto-reticulate sexine, and minimal modification in the apertural region. The illustrated specimen is relatively large $(30 \mu \mathrm{m})$ although otherwise a close match to $P$. simplex. 


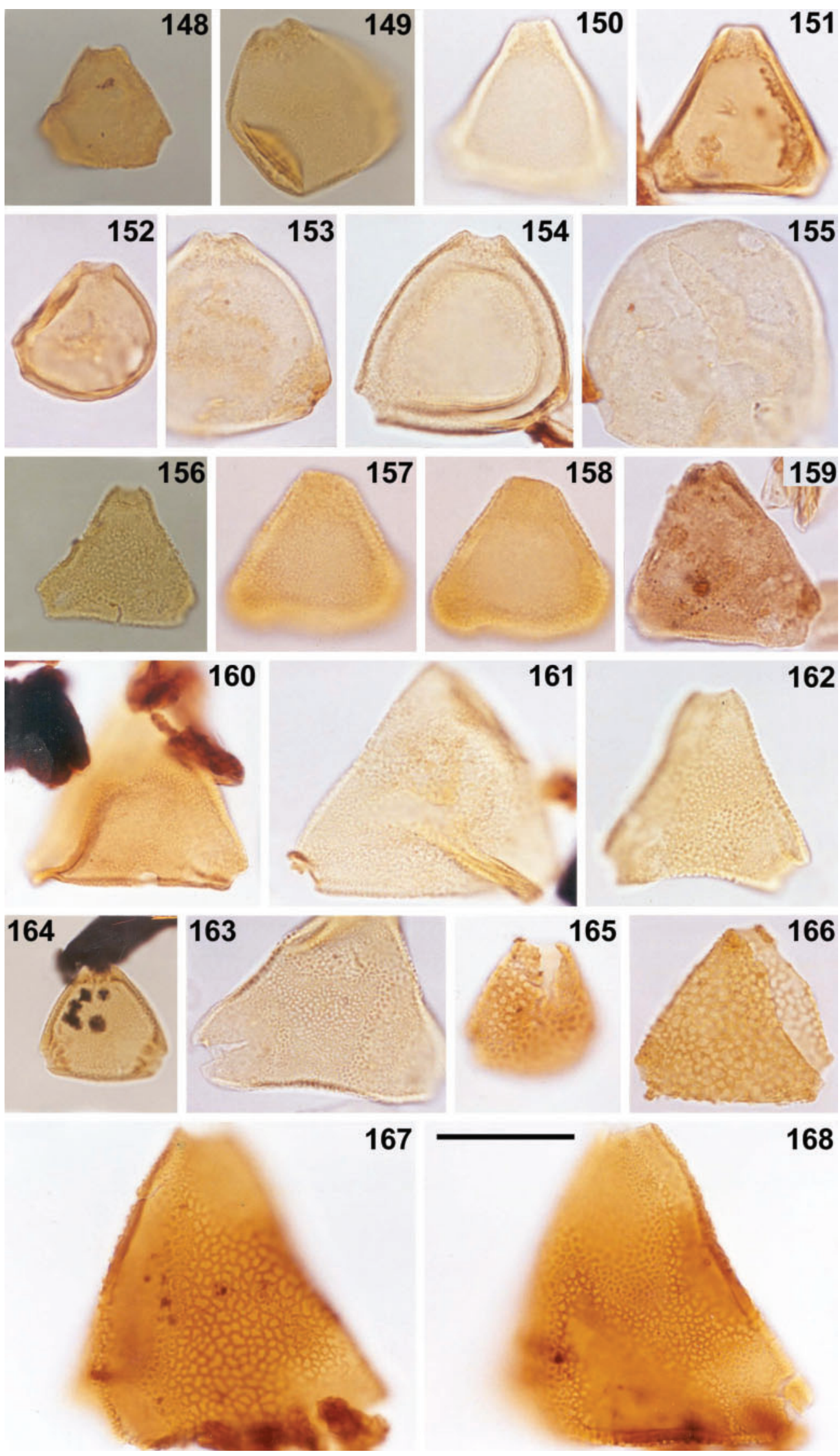


Proteacidites sp. cf. Lewalanipollis trycheros Dettmann \& Jarzen 1996 (Figs 153, 154). The illustrated specimens are characterised by a convex amb, fine scabrate sculpture and a distinctly stratified exine in which the sexine thickens around the pore margins, whereas the nexine, which breaks up into 'island fragments' and channels in the apoporal regions, forms pseudo-vestibulae. The morphotype is similar to L. trycheros, described from Late Cretaceous deposits in the Otway Basin (cf. figs $9 A-G, 10 A-E$, p. 116 in Dettmann and Jarzen 1996), except that it has much finer sculpturing across the surface of the grain and around the apertures. Triporopollenites sp. 1, which has been recovered from the McMurdo erratics, the Weddell Sea and Recent muds in the Ross Sea (Truswell 1983; Mohr 1990; Askin 2000), differs in having a more circular amb, sparsely distributed grana across the surface of the grain and less well defined breakdown of the nexine around the pores. Dettmann and Jarzen (1996) commented that the aperture structure in L. trycheros is similar to that in pollen of the subfamilies Proteoideae and Persoonioidae, and suggested an affinity with extant Stirlingia (form species P. punctiporus Macphail \& Truswell 1993). The somewhat smaller grain illustrated in Fig. 152 exhibits the same thickening of the exine around the pore margins.

Proteacidites sp. aff. P. sinulatus Dudgeon 1983 (Figs 178-181). The illustrated specimens are similar to P. sinulatus Dudgeon 1983 in that the nexine is strongly thickened in the mesocolpial region. Unlike the latter species, which is microreticulate, the Prydz Bay specimens are characterised by a medium open reticulum in which the lumina may decrease in size across the poles.

Proteacidites sp. A (Fig. 148). Scabrate grain characterised by weakly defined 'collars' around the pores.

Proteacidites sp. B (Figs 157, 158). Finely reticulate grain characterised by thick exine that thins towards the 'blunt' apertures.
Proteacidites sp. C (Fig. 160). Large, microreticulate grain characterised by exine that thins slightly towards the apertures.

Proteacidites sp. D (Fig. 165). Grains assigned to this morphospecies are characterised by a small size $(\sim 20 \mu \mathrm{m})$, convex amb, simple, unthickened pore structure, and a medium open reticulate sculpture in which (i) the muri are underlain by single to double rows of columellae and (ii) the polygonal lumina diminish in size towards the pores. The Miocene species $P$. symphyonemoides Cookson 1950 is superficially similar and is distinguished by a straight-sided triangular $\mathrm{amb}$ and labrynthine reticulum. Milne (1998) proposed that small reticulate proteaceous types may be of both stratigraphic and phylogenetic value in the Eocene. However, diagnostic characters, such as the plaited or interwoven form of the muri in her species $P$. cirritulus are visible only with scanning electron microscope. The modern affinity is unknown.

Proteacidites sp. (Fig. 155). Scabrate triporate pollen grain in oblique polar view showing circular pores and? scattered granules.

Propylipollis sp. cf. P. tenuiexinous (Stover \& Partridge) Dettmann \& Jarzen 1996 (Fig. 161). The morphotype illustrated in Fig. 161 is characterised by its large size, triangular amb, thin exine and scabrate ornamentation. The minor thickening of the nexine around the apertures has been used by Dettmann and Jarzen (1996) to transfer Proteacidites tenuiexinus to Propylipollis and the same feature is present in the Prydz Bay specimen. Dettmann and Jarzen (ibid) considered closely similar forms to be representative of the Grevillioideae.

Propylipollis? sp. A (Figs 150, 151). This morphospecies is distinguished by the finely scabrate sculpture and thickening of the nexine around the apertures to form vestibulae. The Prydz Bay specimens are not dissimilar to $P$. concretus (Harris) Martin \& Harris 1975, which has not been recorded

Figs 148-168. Fig. 148. Proteacidites sp. A; scabrate triporate pollen grain in polar view, showing weakly defined apertural 'collars'; $142.5 \mathrm{~m}$ below the modern sea floor (mbsf). Fig. 149. Proteacidites sp. cf. P. simplex Dudgeon 1983; puncto-reticulate triporate pollen grain in polar view, showing 'apertural collars'; 156.99 mbsf. Figs 150, 151. Propylipollis? sp. A. Fig. 150. Triporate pollen grain in surface polar view, showing faintly scabrate ornamentation and straight sides; 156.99 mbsf. Fig. 151. Triporate pollen grain in median polar view, showing characteristic thickening of the nexine around the apertures; 170.98 mbsf. Figs 152-154. Proteacidites sp. cf. Lewalanipollis trycheros Dettmann \& Jarzen 1996. Fig. 152. Stripped triporate pollen grain in oblique polar view; 148.36 mbsf. Fig. 153. Scabrate triporate pollen grain in oblique polar view, showing thick sexine and thickening of the nexine below the aspidate pores; 156.99 mbsf. Fig. 154. Scabrate triporate pollen grain in oblique polar view, characterised by thin sexine and thickening of the nexine below the aspidate pores; $180.4 \mathrm{mbsf}$. Fig. 155. Proteacidites sp. Scabrate triporate pollen grain in oblique polar view, showing circular pores and? scattered granules; $142.5 \mathrm{mbsf}$. Fig. 156. Proteacidites pseudomoides Stover \& Partridge 1973; reticulate triporate pollen grain in polar view; 142.5 mbsf. Figs 157, 158. Proteacidites sp. B. Fig. 157. Reticulate triporate pollen grain in surface polar view, showing blunt apices; $142.5 \mathrm{mbsf}$. Fig. 158. Same grain in median polar view, characterised by thick nexine, which thins around the pores. Fig. 159. Proteacidites sp. cf. P. nitidus Dudgeon 1983; triporate pollen grain in oblique polar view, characterised by marked thickening of the nexine around the pores and fine even reticulate ornamentation; $142.5 \mathrm{mbsf}$. Fig. 160. Proteacidites sp. C; folded triporate pollen grain in polar view, characterised by large size, very fine reticulate ornamentation and thinning of the exine around the pores; 156.99 mbsf. Fig. 161. Propylipollis sp. cf. P. tenuiexinus (Stover \& Partridge) Dettmann \& Jarzen 1996; folded triporate pollen grain in polar view, characterised by very thin wall and scabrate ornamentation; 156.99 mbsf. Fig. 162. Proteacidites sp. cf. P. adenanthoides Cookson 1950; triporate pollen grain in polar view, characterised by punctoreticulate ornamentation and exine that thins towards the pores; $156.99 \mathrm{mbsf}$. Fig. 163. Proteacidites sp. cf. P. reflexus Stover \& Partridge 1973; triporate pollen grain in polar view, characterised by reticulate ornamentation and slight thickening of the exine in the mesocolpial regions; 142.5 mbsf. Fig. 164. P. crassimarginus Dudgeon 1983; triporate pollen grain in polar view, characterised by puncto-reticulate ornamentation and striate-crassimarginate pores; 170.98 mbsf. Fig. 165. Proteacidites sp. D; small triporate pollen grain in polar view, characterised by open reticulate ornamentation in which the muri are underlain by double rows of columellae; $156.99 \mathrm{mbsf}$. Fig. 166. Proteacidites sp. cf. P. retiformis Couper 1960; relatively large triporate pollen grain in polar view, characterised by open reticulate ornamentation in which the muri are underlain by single rows of columellae; 156.99 mbsf. Figs 167 , 168. Proteacidites sp. cf. P. differentipolus Dudgeon 1983. Fig. 167. Large triporate pollen grain in bottom polar view, characterised by marked difference in the size of the lumina across opposing poles; 170.98 mbsf. Fig. 168. Same grain in top polar view, characterised by marked difference in the size of the lumina across opposing poles. Scale bar $=25 \mu \mathrm{m}$. 

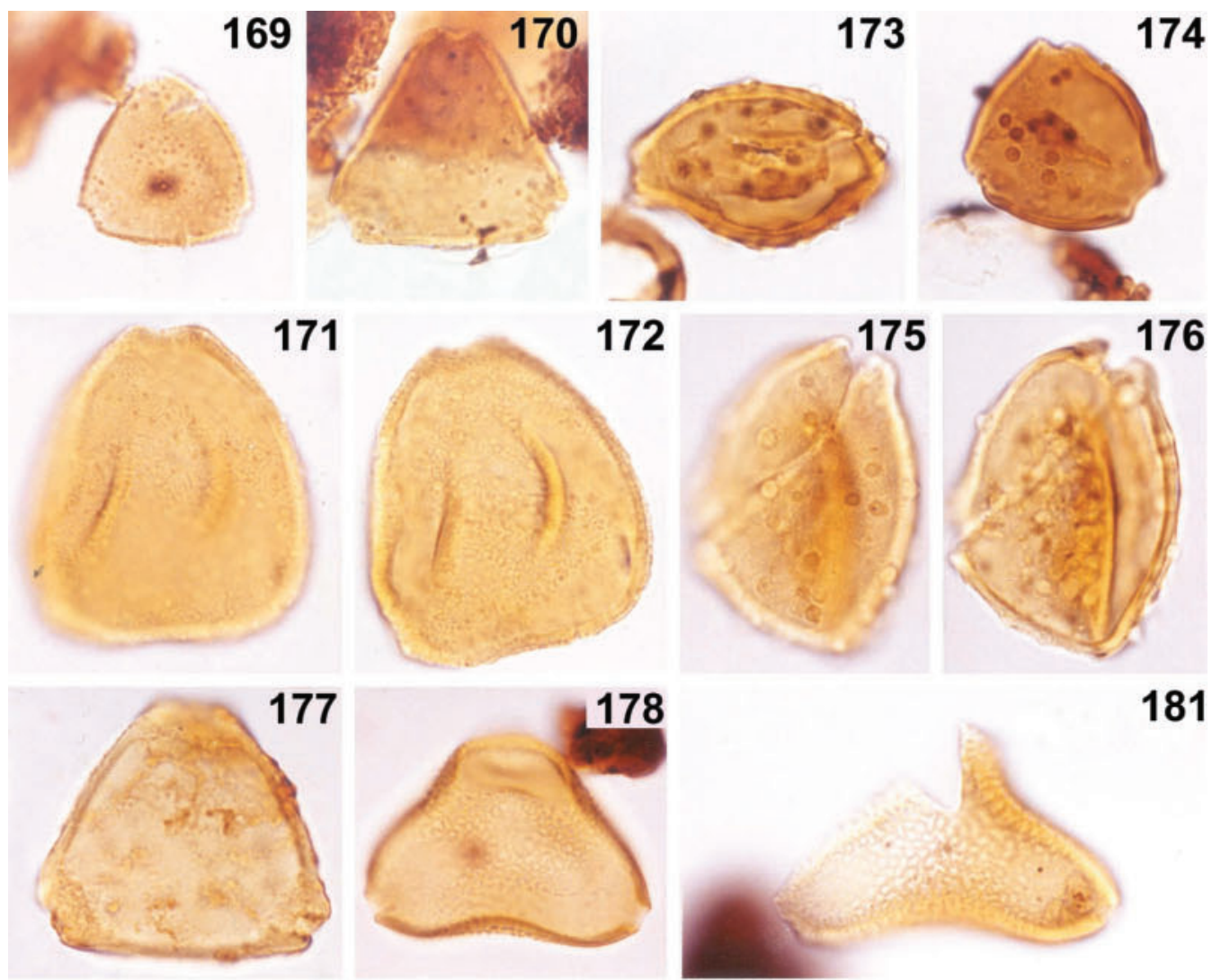

181

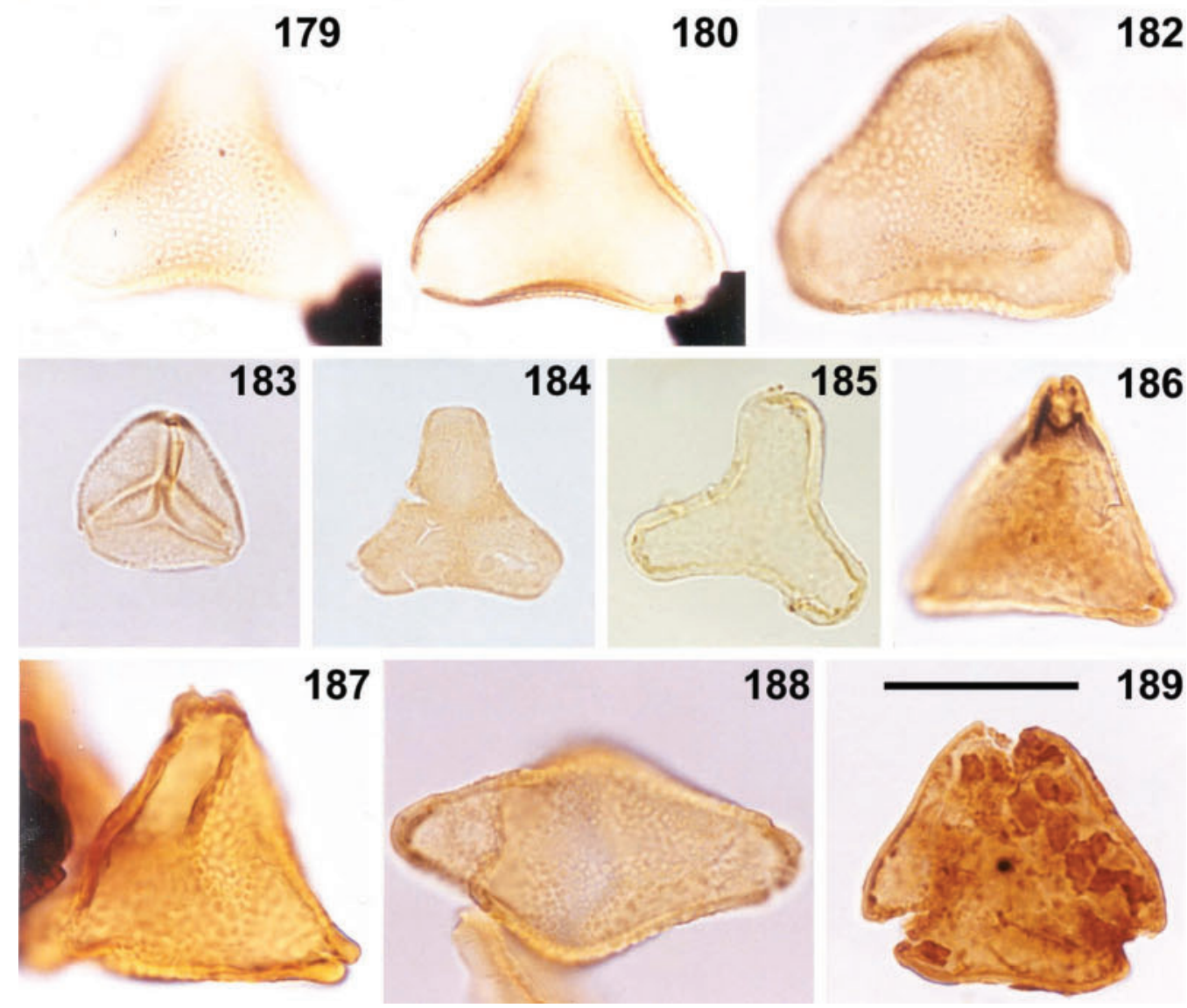


before in Antarctica. Dettmann and Jarzen (1996) considered $P$. concretus to be similar to the pollen of Macadamia and several other genera within the tribe Macadamieae.

Propylipollis? sp. B (Fig. 169). This psilate morphotype resembles $P$. ambiguus (Stover \& Partridge) Dettmann \& Jarzen 1996 in being ornamented with fine apiculae although it is usually smaller and lacks the distinctive thickening around the pore that characterises the latter species (cf. plate 21, fig. 7 in Stover and Partridge 1973). P. ambiguus, which occurs in the McMurdo erratics (Askin 2000), has been compared to modern pollen of Telopea truncata by Dettmann and Jarzen (1996).

Propylipollis? sp. C (Figs 171, 172). This morphotype also resembles $P$. ambiguus (Stover \& Partridge) Dettmann \& Jarzen 1996 in being ornamented with scattered spinules, except that it is larger and characterised by a distinctly stratified, punctoreticulate exine that thickens around the pores (cf. plate 21, fig. 7 in Stover and Partridge 1973).

Propylipollis? sp. D (Figs 173-176). This distinctive morphotype broadly resembles $P$. obscurus Cookson 1950 in that the faintly scabrate exine thins at the pore; however, it differs from the latter species in being ornamented with non-deciduous and irregularly scattered large circular verrucae and gemmae. The morphotype is a rare component of Early to basal Middle Eocene microfloras in south-eastern Australia where it is recorded as the manuscript species P. lapis (see also plate 6, fig. 14 in Macphail and Truswell 2004a).

Propylipollis? sp. E (Fig. 177). Rare grain ornamented by irregular swelling of the sexine and showing marked thickening of the exine around the pores.

\section{Sapindaceae}

Cupanieidites sp. cf. C. orthoteichus Cookson \& Pike 1954 (Fig. 183). Specimens of Cupanieidites Cookson \& Pike 1954 occur in three samples from the upper section at Site 1166. Stover and Partridge (1973) noted that Australian species assigned to this parasyncolporate fossil pollen type cannot be reliably differentiated by size, exine thickness, reticulate ornamentation and size and outline of the polar island. For the same reason, we have compared the Prydz Bay specimens to the most commonly encountered species (Cupanieidites orthoteichus). C. orthoteichus has been recorded in the Late Cretaceous (Maastrichtian) sequences on Seymour Island (Askin 1989, 1990a), in the Middle Eocene sequences from the same locality (Askin 1997) and occurs as a recycled element in the Ross Sea and Recent muds from Cape Carr, East Antarctica (Truswell 1983). The morphotype appears to be unique to the Tribe Cupanieae of the Sapindaceae, suggesting that representatives of one clade of Sapindaceae were growing at Prydz Bay during the Late Eocene. Living Sapindaceae encompass trees, shrubs, lianes and herbaceous climbers, most of which are confined to warm-temperate to tropical environments. The Prydz Bay data indicate that one or more now extinct ecotypes were adapted to colder, winter-dark conditions.

\section{Trimeniaceae}

Periporopollenites sp. cf. P. demarcatus Stover \& Partridge 1973 (Fig. 208). The crushed, periporate specimen illustrated in Fig. 208 is provisionally referred to $P$. demarcatus Stover \& Partridge 1973, on the basis of its polygonal shape and subequatorial circular? pores. The morphotype differs from $P$. hexaporus (Figs 209, 210) in the number of pores $(>6)$ and fine puncto-reticulate sculpture. $P$. demarcatus is usually considered to be a fossil member of the Trimeniaceae family.

\section{Angiophyta of unknown affinity}

At least 25 angiosperm pollen types, whose modern affinities (if any) are unknown, are present in the Late Eocene section at Prydz Bay. These fall into the following two distinct groups: (1) formally described although extinct morphospecies and (2) undescribed morphotypes provisionally assigned to tricolpate (Tricolpites Cookson ex Couper 1953), tricolporate (Rhoipites Wodehouse 1933, Tricolporites Cookson 1947) or tetrahedral (Tetradopollenites Thompson \& Pflug 1953,

\footnotetext{
Figs 169-189. Fig. 169. Propylipollis? sp. B; small triporate pollen grain in polar view, characterised by thin exine ornamented with irregularly scattered spinulae; $156.99 \mathrm{~m}$ below the modern sea floor (mbsf). Fig. 170. cf. Cranwellipollis apiculatus (Stover \& Partridge) Dettmann \& Jarzen 1996; triporate pollen grain in polar view, characterised by relatively thick exine ornamented with spinules and small verrucae clustered around the pores; 156.99 mbsf. Figs 171, 172. Propylipollis? sp. C; triporate pollen grain in oblique polar view, characterised by puncto-reticulate sexine with scattered spinules; 156.99 mbsf. Figs 173-176. Propylipollis? sp. D. Fig. 173. Triporate pollen grain in equatorial view, characterised by irregularly scattered large verrucae and nexine which thins around the pores; $170.98 \mathrm{mbsf}$. Fig. 174. Grain in polar view, showing sparse verrucae; $170.98 \mathrm{mbsf}$. Figs 175, 176. Crushed triporate pollen grain in oblique surface polar view, characterised by irregularly scattered large verrucae; 156.99 mbsf. Fig. 177. Propylipollis? sp. E; triporate pollen grain in polar view, ornamented by irregular swelling of the sexine and showing marked thickening of the exine around the pores; 156.99 mbsf. Figs 178-181. Proteacidites sp. aff. P. sinulatus Dudgeon 1983. Fig. 178. Reticulate triporate pollen grain in polar view, characterised by marked thickening of the nexine in the mesocolpial region; 156.99 mbsf. Figs 179, 180. Reticulate triporate pollen grain in surface polar view, showing even open reticulate ornamentation; 170.98 mbsf. Fig. 180. Same grain in median polar view, showing marked thickening of the nexine in the mesocolpial region. Fig. 181. Reticulate triporate pollen grain in surface polar view, showing even open reticulate ornamentation; $180.4 \mathrm{mbsf}$. Fig. 182. Proteacidites sp. aff. P. kopiensis Harris 1972 ; reticulate triporate pollen grain in surface polar view, characterised by a marked increase in the size of the lumina towards the amb and thickening of the nexine in the mesocolpial region; 170.98 mbsf. Fig. 183. Cupanieidites orthoteichus Cookson \& Pike 1954; syncolporate reticulate pollen grain; 156.99 mbsf. Figs 184, 185. Battenipollis sectilis (Stover \& Partridge) Jarzen \& Dettmann 1992. Fig. 184. Torn tricolporate pollen grain in surface polar view, characterised by thin exine and transverse (equatorially aligned) colpi; $142.5 \mathrm{mbsf}$. Fig. 185. Tricolporate pollen grain in median polar view, showing relatively thick exine and transverse colpi; 142.5 mbsf. Figs 186-188. Forcipites sabulosus (Dettmann \& Playford) Dettmann \& Jarzen 1988. Fig. 186. Tricolporate pollen grain in polar view, characterised by verrucate ornamentation and longitudinally aligned colpi; $148.36 \mathrm{mbsf}$. Fig. 187. Tricolporate pollen grain in polar view, showing strong thickening of the exine around the pores; 156.99 mbsf. Fig. 188. Tricolporate pollen grain in equatorial view; 142.5 mbsf. Fig. 189. Forcipites sp. cf. F. stipulatus Dettmann \& Jarzen 1988; tricolporate pollen grain in polar view, characterised by weakly scabrate (stippled) ornamentation and unthickened aperture margins; $180.4 \mathrm{mbsf}$. Scale bar $=25 \mu \mathrm{m}$.
} 

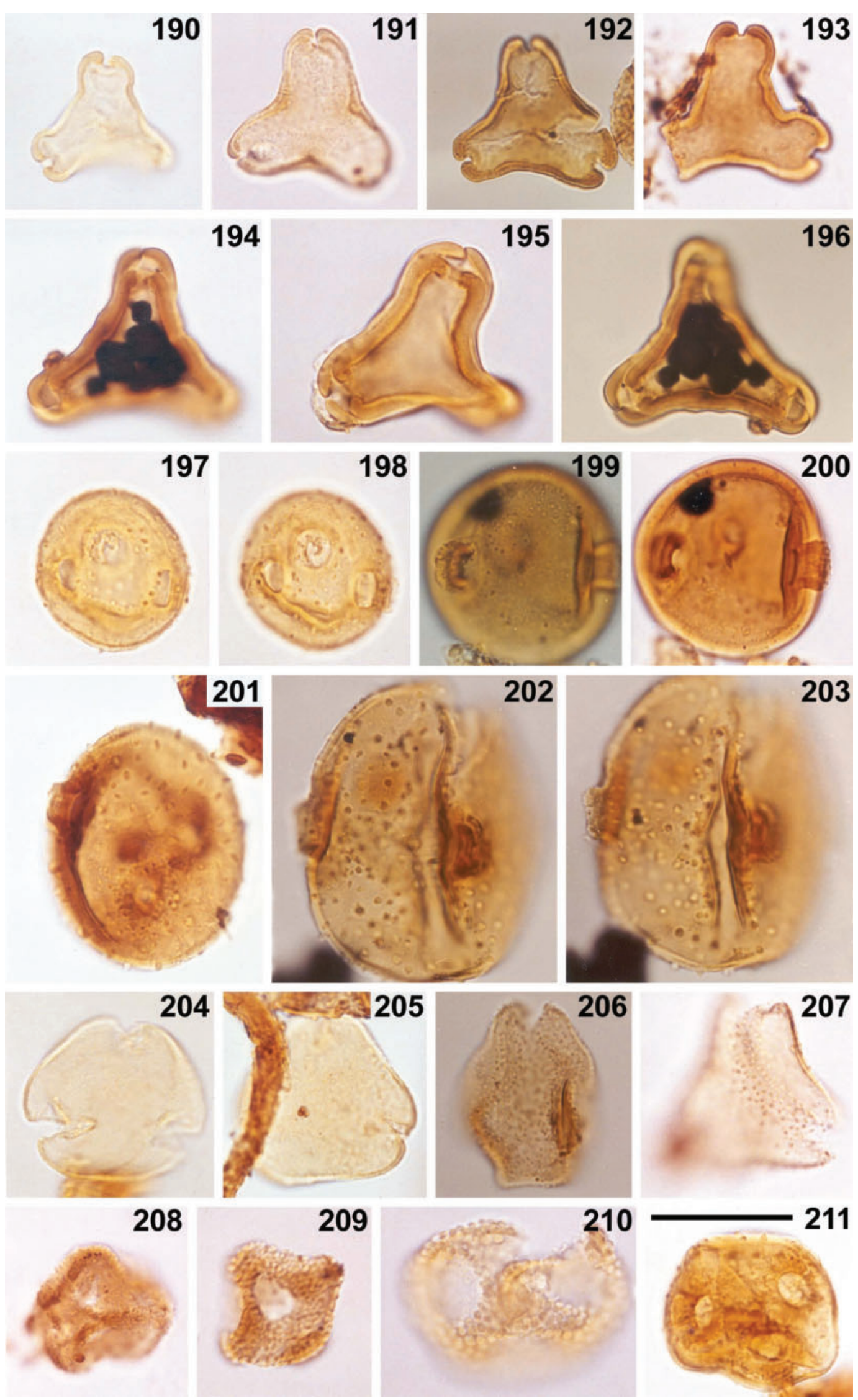

210

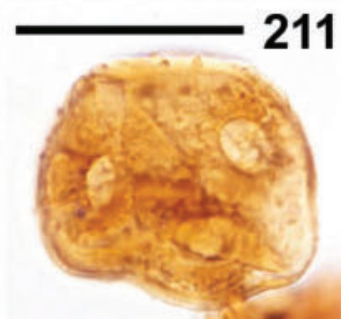


Triporotetradites Van Hoeken-Klinkenberg 1964) fossil genera. The morphotypes in the latter group are rare to very rare (1 or 2 specimens) and, less certainly, may not have been recorded elsewhere. The figured specimens represent those morphotypes for which we have been able to provide brief descriptions, despite the often-flattened condition and/or or poor orientation. The multiplicity of forms points to a moderately diverse subcanopy and ground flora within the pollen-source area, although the presence of some reworked forms cannot be discounted.

Battenipollis sectilis (Stover \& Partridge) Jarzen \& Dettmann 1992 (Figs 184, 185). This Late Cretaceous morphospecies, originally described as Triporopollenites sectilis Stover \& Partridge 1973, accommodates breviaxial, oblate pollen, with equatorially aligned (transcolpate) apertures. The species occurs as a recycled element in Recent muds in the Ross Sea Truswell (1983) and Campanian to Maastrichtian sequences on Seymour Island (Askin 1990a). It is unclear whether the Prydz Bay specimens are in situ or recycled. No living plants produce pollen of this morphotype (cf. Jarzen and Dettmann 1992) and the taxon is presumed to be extinct.

Forcipites sabulosus (Dettmann \& Playford) Dettmann \& Jarzen 1988 (Figs 186-188). This Late Cretaceous breviaxial morphospecies, originally described as Tricolpites sabulosus Dettmann \& Playford 1968, differs from Battenipollis in being tricolporate (not transcolpate) and ornamented, with well defined verrucae. Specimens showing unusual thickening of the exine around the endopores (Fig. 187) are retained within F. sabulosus because similar recycled specimens from the Ross Sea (Truswell 1983) were included within the taxon by Dettmann and Jarzen (1988). Like Battenipollis sectilis, the taxon may have become extinct during the latest Cretaceous and comparisons with pollen of extant Symplocos (Symplocaceae) seem to be unsupported (cf. Dettmann and Jarzen 1988). The specimen illustrated in Fig. 189 is characterised by gaping colpi and tentatively compared to Forcipites stipulatus Dettmann \& Jarzen 1988.

Gambierina Harris 1972 (Figs 190-196). Gambierina morphotypes recorded at Prydz Bay are distinguished by possessing complex apertures, which Jarzen and Dettmann (1992) have interpreted as consisting of a meridionally aligned short colpus in the ektexine, and an endexinous pore. Some specimens more closely resemble G. rudata Stover \& Partridge 1973 (Figs 190-194) whilst others are closer to G. edwardsii (Cookson \& Pike) Harris 1972 (Figs 194-196). Criteria used by Stover and Partridge (1973) to distinguish G. rudata from G. edwardsii are its smaller size, generally thinner exine, lack of a 'nick point' within the aperture and by indentations in the mesocolpial regions. We concur with Jarzen and Dettmann (1992) that the two morphospecies are end points in a morphological continuum. Accordingly, we have assigned the smaller, thinner-walled forms to G. rudata and note that some of these exhibit distinct mesocolpial thickening (see Fig. 191).

Morphotypes compared to Gambierina edwardsii (Figs 194-196) are larger and thicker-walled but do not show the apertural 'nick point' or the pronounced thickening of the exine, which give the apertures in G. edwardsii their 'boxing glove' appearance in polar view (cf. Macphail et al. 1994, fig. 10.9s); instead the two wall layers separate to form vestibulae above the endopores. In Australia, G. edwardsii first appears later, and is usually much rarer, than G. rudata (Late $v$. Early Campanian) and both species become extinct at about the same time in the earliest Early Eocene in south-eastern Australia (Partridge 1999). Antarctic records of both morphospecies are rare. G. edwardsii occurs as a recycled element in the Ross Sea (Truswell 1983) and has not been recorded from the McMurdo Sound erratics (Askin 2000), nor

Figs 190-211. Figs 190-193. Gambierina rudata Stover \& Partridge 1973. Fig. 190. Tricolporate concavely triangular pollen grain in polar view, showing faint scabrate ornamentation and characteristic thickening of exine around aperture; exine not thickened in mesocolpial region; $156.99 \mathrm{~m}$ below the modern sea floor (mbsf). Fig. 191. Tricolporate concavely triangular pollen grain in polar view, showing scabrate ornamentation and characteristic thickening of stratified exine around aperture; exine thickened in mesocolpial region; $156.99 \mathrm{mbsf}$. Fig. 192. Tricolporate concavely triangular pollen grain in polar view, showing faint triradiate band of darkened exine across the pole; stratified exine not thickened in mesocolpial region; 156.99 mbsf. Fig. 193. Tricolporate strongly concave pollen grain in polar view, showing faint triradiate band of darkened exine across the pole; stratified exine thickened in mesocolpial region; 156.99 mbsf. Figs 194-196. Gambierina sp. cf. G. edwardsii (Cookson \& Pike) Harris 1972. Figs 194, 196. Tricolporate concavely triangular pollen grain in polar view, showing thick stratified exine with a pronounced vestibule forming between the inner and outer layers at the apices; 'nick point' developed in mesocolpial region; 156.99 mbsf. Fig. 195. Tricolporate concavely triangular pollen lacking 'nick point'; 148.36 mbsf. Figs 197-200. Integricorpus sp. (Type A). Figs 197, 198. Small sphaeroidal triprojectate pollen grain in surface equatorial view, characterised by poorly defined apertures located on the termini of short tube-like extensions of the exine around the main body; ornamented with evenly distributed spinules; 156.99 mbsf. Figs 199, 200. Ovoid triprojectate pollen grain in surface and median equatorial view, characterised by thick stratified exine, which extends to form short tube-like extensions around the equator; ornamented with evenly distributed spinules; 156.99 mbsf. Figs 201-203. Integricorpus sp. (Type B). Fig. 201. Large ellipsoidal triprojectate pollen grain in surface equatorial view, characterised by thick stratified exine, which extends to form short tube-like extensions around the equator; ornamented with robust, evenly distributed pointed spinules; $156.99 \mathrm{mbsf}$. Figs 202, 203. Large ellipsoidal triprojectate pollen grain in median and surface equatorial view, characterised by thick stratified exine, which extends to form short tube-like extensions around the equator; ornamented with robust, evenly distributed pointed spinules; 170.98 mbsf. Figs 204, 205. Peninsulapollis gillii (Cookson) Dettmann \& Jarzen 1988. Fig. 204. Faintly scabrate tricolpoidate pollen grain in oblique polar view, characterised by convexly triangular amb with rounded apices and ragged margins to colpi; 156.99 mbsf. Fig. 205. Tricolpoidate pollen grain in oblique polar view; 156.99 mbsf. Figs 206, 207. Peninsulapollis askiniae Dettmann \& Jarzen 1988. Fig. 206. Tricolpoidate concavely triangular pollen grain showing characteristic spinulose ornamentation; 156.99 mbsf. Fig. 207. Tricolpoidate concavely triangular pollen grain, showing characteristic spinulose ornamentation; 156.99 mbsf. Fig. 208. Periporopollenites sp. cf. P. demarcatus Stover \& Partridge 1973; compressed periporate puncto-reticulate pollen grain; 148.36 mbsf. Figs 209, 210. Periporopollenites hexaporus Macphail \& Hill 1994. Fig. 209. Periporate pollen grain in equatorial view, characterised by six large pores and puncto-reticulate ornamentation; 156.99 mbsf. Fig. 210. Crushed periporate pollen grain in equatorial view, characterised by pseudo-verrucate ornamentation formed by incomplete fusion of the clavate columellae; $156.99 \mathrm{mbsf}$. Fig. 211. Periporopollenites sp. A; periporate tectate pollen grain in oblique equatorial view, characterised by 10 ? large pores and spinose ornamentation; $180.4 \mathrm{mbsf}$. Scale bar $=25 \mu \mathrm{m}$. 
from the Weddell Sea sequences (Mohr 1990). In West Antarctica, G. rudata occurs in Late Cretaceous sequences on Seymour Island (Askin 1990a) and G. edwardsii in Late Campanian to Maastrichtian sequences on Vega Island (see Jarzen and Dettmann 1992). It is uncertain whether the Prydz Bay specimens are recycled, or whether the parent plants were able to survive in Antarctica into Eocene time because of the persistence of cool-cold, winter-dark climates. No modern plant taxon produces pollen of this general morphology and the clade is presumed to be extinct.

Triprojectacites spp. cf. Integricorpus (Figs 197-203). The illustrated specimens are provisionally referred to Integricorpus Mtchedlishvili 1961, one of several genera that make up the important, mostly Late Cretaceous, northern hemisphere Triprojectacites Supergroup (Traverse 1988, figs 13.11, 13.12). At least two morphotypes occur at Prydz Bay, both of which are characterised by a central body from which arise three symmetrically arranged equatorial projections, each of which is part of a meriodinally aligned colpus and terminates in a pore. The first, Type A (Figs 197-200), is characterised by its relatively small, subcircular shape in an equatorial view and spinulose ornamentation; the second, Type B (Figs 201-203), is characterised by its relatively large oval to elliptical shape in an equatorial view, amb, thick exine, short robust projections and robust apiculate ornamentation. A presumed recycled specimen of Integricorpus Type B occurs in the Early Oligocene sediments in Cape Roberts Drillhole CRP-3 (?Campanulaceae of Raine and Askin 2001). The Prydz Bay specimens are likely to be the first in situ record of this Supergroup in Antarctica, although morphologically similar triprojectate types occur in Maastrichtian sequences in southern, central and northern Australia and in New Zealand (Macphail et al. 1994; A. D. Partridge and M. K. Macphail unpubl. data). The youngest known records in Australia are from Early to Late Eocene (Macphail et al. 1994; M. Dettmann, pers. comm., A. D. Partridge, pers. comm.).

Periporopollenites hexaporus Macphail \& Hill 1994 (Figs 209, 210). This hexaporate morphospecies has previously been recorded in an earliest Oligocene glacial diamicton in north-western Tasmania (Macphail et al. 1993; Macphail and Hill 1994) and a probable Early Miocene coolclimate microflora on the Central Plateau of Tasmania (Macphail et al. 1991). The older Prydz Bay records arguably provide convincing evidence of trans-oceanic plant dispersal from Antarctica to Australia following development of the Antarctic circumpolar current during the Eocene-Oligocene transition (see Exon et al. 2004). No NLR is known and the parent taxon is likely to be extinct.

Periporopollenites sp. A Macphail \& Truswell 2004a (Fig. 211). The morphospecies, informally named P. spinosus ms by Macphail and Truswell (2004a), differs from P. hexaporus Macphail \& Hill 2004 in being larger and having coni scattered across the exine. The superficially similar Late Oligocene-Miocene species Sparsipollis pappilatus Mildenhall \& Crosbie 1979 differs from the Prydz Bay morphotype in being ornamented by long (up to $3 \mu \mathrm{m}$ ), often deciduous papillae, and not coni.

Peninsulapollis askiniae Dettmann \& Jarzen 1988 (Figs 206, 207). This tricolporoidate pollen with a distinctive spinulose ornamentation has been recorded in Campanian-Paleocene sediments on Vega Island (Dettmann and Jarzen 1988). Askin $(1992,2000)$ noted the presence of the species in the Eocene sequence on Seymour Island and has recorded two poorly preserved specimens from the McMurdo erratics. The morphotype is questionably attributed to the Proteaceae (Askin 1992, 2000).

Peninsulapollis gillii (Cookson) emend. Dettmann \& Jarzen 1988 (Figs 204, 205). This finely scabrate morphospecies, which occurs in the Middle to Late Eocene sections at Site 1166 (Macphail and Truswell 2004a), conforms well to the emended description given by Dettmann and Jarzen (1988, p. 223). Macphail and Truswell (2004a) referred the specimens to the microreticulate species Tricolpites fissilis Couper 1960 and records from Site 270 in the Ross Sea (Kemp 1975) have been cited under the same name. P. gillii and Peninsulapollis sp. cf. $P$. gillii have been recorded in Late Cretaceous and Middle Eocene sequences in West Antarctica (Dettmann and Jarzen 1988; Mohr 1990), the McMurdo erratics (where it is considered to be a reworked occurrence), the Early Oligocene section of Cape Roberts Drillhole CRP-3 and in Recent muds in the Ross Sea area (Truswell 1983; Askin 2000; Raine and Askin 2001), and are widely distributed in Late Cretaceous to Eocene sequences in southern Australia, New Zealand and South America. The affinity is unknown, although Dettmann and Jarzen (1988) pointed to a 'striking resemblance' to pollen of Beauprea filipes.

Peninsulapollis truswelliae Dettmann \& Jarzen 1988 (not illustrated). This morphospecies is distinguished from other Peninsulapollis spp. by a clearly stratified exine, thinning of the sexine towards the ragged colpus margins and a surface texture of fine baculae and grana. The type is widespread in Antarctica, with a range extending from the Campanian-Maastrichtian on the Antarctic Peninsula (Dettmann and Jarzen 1988) to the Oligocene on the Falkland Plateau (Bratzeva 1983). Askin (2000) reported closely similar forms as $P$. cf. truswelliae from the Eocene erratics at McMurdo Sound. Affinities are uncertain although Dettmann and Jarzen (1988) noted that the sculpture is similar to that found on Beauprea filipes pollen.

Rhoipites sp. A (Fig. 212). This subprolate, tricolporate, delicately reticulate morphotype is characterised by long, apparently narrow colpi, which extend from near the poles, and rectangular, lalongate endopores, underlain by strongly thickened nexine. The labrynthine muri are underlain by double rows of distinct columellae. The size of the specimen is $26 \times 24 \mu \mathrm{m}$ (1 specimen).

Rhoipites sp. B (Fig. 213). This subprolate, tricolporate, reticulate morphotype is characterised by broad colpi extending from near the poles and poroid? endoapertures that may be floored by a nexine membrane. The muri are underlain by single rows of columellae whereas the polygonal lumina decrease in size towards poles and adjacent to colpal margins. The size of the specimen is $24 \times 20 \mu \mathrm{m}$ ( 1 specimen).

Rhoipites sp. C (Fig. 214). The illustrated specimen is similar to Rhoipites sp. B except that it possesses colpi which narrow towards the pole, apparently circular? endopores and a 
thicker $(\sim 2.5 \mu \mathrm{m})$ sexine. The size of the specimen is $24 \mu \mathrm{m}$ (1 specimen).

Rhoipites sp. D (Fig. 215). The illustrated specimen differs from Rhoipites sp. B and Rhoipites sp. C in that the lumina increase markedly in size across the mesopcolpial region. The same feature occurs in a more highly developed form in Dryadopollenites retequetrus (Stover \& Partridge) Pocknall \& Mildenhall 1984. The size of the specimen is $26 \mu \mathrm{m}$ (1 specimen).

Rhoipites sp. E (Figs 216, 217). The illustrated specimens represent the most distinctive Rhoipites sp. recorded at Prydz Bay. The morphotype is characterised by long, narrow colpi extending from near the poles, and elliptical, lalongate endopores. The sexine is thin $(1.5 \mu \mathrm{m}$ thick), relative to the size of the grain, and thickens across poles; the near circular lumina tend to increase in diameter in the same direction. Size range of the specimen is $\sim 38 \times 18-28 \mu \mathrm{m}$ (2 specimens).

Tetracolporites verrucosus Stover \& Partridge 1973 (Fig. 218). This typically Late Cretaceous to Danian morphospecies is characterised by closely spaced clavae and longitudinal colpi with strongly thickened margins that diverge away from the equator. The illustrated specimen is prolate although oblate forms are also recorded in south-eastern Australia.

Tetradopollenites spp. (Figs 220,221). The relatively small tetrahedral pollen tetrads illustrated in Figs 220, 221 are provisionally referred to Tetradopollenites Thompson \& Pflug 1953, on the basis of well defined colpi. The specimen illustrated in Fig. 221 is similar to Ericipites Wodehouse 1933, except that the sculpture is microreticulate not psilate to scabrate. The sculpture in Dicotetradites (Harris) Crosbie \& Clowes 1980 is similar except that the individual monads are triporate. The specimen sizes are 22 and $26 \mu \mathrm{m}$ (2 specimens).

Triporotetradites spp. (Figs 219, 222). The small to large tetrahedral pollen tetrads illustrated in Figs 219 and 222 are provisionally referred to Triporotetradites Van HoekenKlinkenberg 1964, on the basis of the pore-like nature of the apertures. It is unclear whether the palynomorphs comprise immature pollen grains that were usually dispersed as monads or mature pollen grains that were dispersed in obligate tetrads. The speciment sizes are 24 and $49 \mu \mathrm{m}$ ( 2 specimens).

Tricolpites sp. cf. T. asperamarginis McIntyre 1968. (Figs 95-97). This species encompasses small tricolpate pollen grains with gaping colpi, and a finely scabrate exine. From Antarctica, it has been reported as a recycled element in Recent Ross Sea muds (Truswell 1983), and again probably as recycled in Neogene sequences in the same area (Warny et al. 2006). It has also been described from probable Oligocene sediments on the Ninetyeast Ridge, Indian Ocean (Kemp and Harris 1977). It differs from T. trioblatus Mildenhall \& Pocknall 1989 in showing a less obvious columellate wall structure. Affinities are unclear. Mildenhall and Pocknall (1989) noted the similarities of both $T$. asperamarginis and $T$. trioblatus to taxa within the Scrophulariaceae, whereas Martin (2001) proposed that T. trioblatus represents a fossil member of the Convulvulaceae.
Tricolpites confessus Stover \& Partridge 1973 (Fig. 223). The psilate oblate pollen grain illustrated in Fig. 223 closely resembles $T$. confessus in that the exine thins sharply towards the colpal margins. The specimen size is $18 \mu \mathrm{m}$ (1 specimen).

Tricolpites sp. A (Fig. 224). The illustrated specimen is characterised by its strongly oblate shape, circular amb, gaping colpi and scabrate sculpture. The morphotype is similar to Peninsulapollis Dettmann \& Jarzen 1988 in possessing colpi with ragged margins, whereas it has a circular amb and faintly columellate exine. The size of the specimen is $24 \mu \mathrm{m}$ (1 specimen).

Tricolpites sp. B (Fig. 225). The illustrated specimen is characterised by its prolate shape, indistinct puncto-reticulate sculpture and thick exine relative to its size. The size of the specimen is $17 \times 14 \mu \mathrm{m}$ ( 1 specimen).

Tricolpites sp. C (Fig. 226). The illustrated specimen is characterised by its strongly prolate shape and delicate fine reticulate sculpture. The morphotype is similar to modern Brassicaceae pollen and may be a modern contaminant. The size of the specimen is $30 \times 15 \mu \mathrm{m}$ (1 specimen).

Tricolpites sp. D (Figs 227, 228). The illustrated specimen differs from Tricolpites sp. $\mathrm{C}$ in its larger size and the labrynthine appearance of the muri. The lumina decrease in size towards the poles and colpal margins. The size of the specimen is $34 \times 24 \mu \mathrm{m}$ (1 specimen).

Tricolporites sp. A (Figs 229, 230). This distinctive psilate, prolate grain is characterised by strongly thickened colpal margins (costae) that diverge towards the poles. The obscured endopores appear to be elliptical in shape. The size of the specimen is $18 \times 14 \mu \mathrm{m}$ ( 1 specimen).

Tricolporites sp. B (Figs 231-233). This prolate morphotype is characterised by the psilate appearance of the relatively thick tectate-microreticulate exine, very fine columellae and (Fig. 233) diamond-shaped, strongly lalongate endopores, which may be underlain by granular nexine. The specimen size range is $19-22 \times 14-19 \mu \mathrm{m}$ ( 3 specimens).

Tricolporites sp. C (Fig. 234). The illustrated morphotype is characterised by its subsphaeroidal shape, microreticulate sculpture and strong thickening of the nexine along the narrow colpi and below the slit-shaped? endopores. The size of the specimen is $\sim 26 \mu \mathrm{m}$ ( 1 specimen).

Tricolporites sp. D (Fig. 235). The illustrated morphotype is characterised by its large, subsphaeroidal shape, fine reticulate sculpture, broad colpi with blunt apices near the poles and apparent thickening of the nexine along the narrow colpi and below the slit-shaped? endopores. The size of the specimen is $\sim 36 \mu \mathrm{m}$ (1 specimen).

The dinoflagellate cyst Paucilobimorpha spinosus (Cookson) Partridge 1999 is illustrated in Fig. 238. What is believed to be a cuticle fragment from an unidentified micro-invertebrate is illustrated in Fig. 239.

\section{Discussion}

Polar forests and woodlands (the Austral conifer forest) adapted to survive up to 6 months of total darkness have occupied the Antarctic continent from the Early Mesozoic into the middle Cenozoic (see Jefferson 1982; Truswell 1990; 


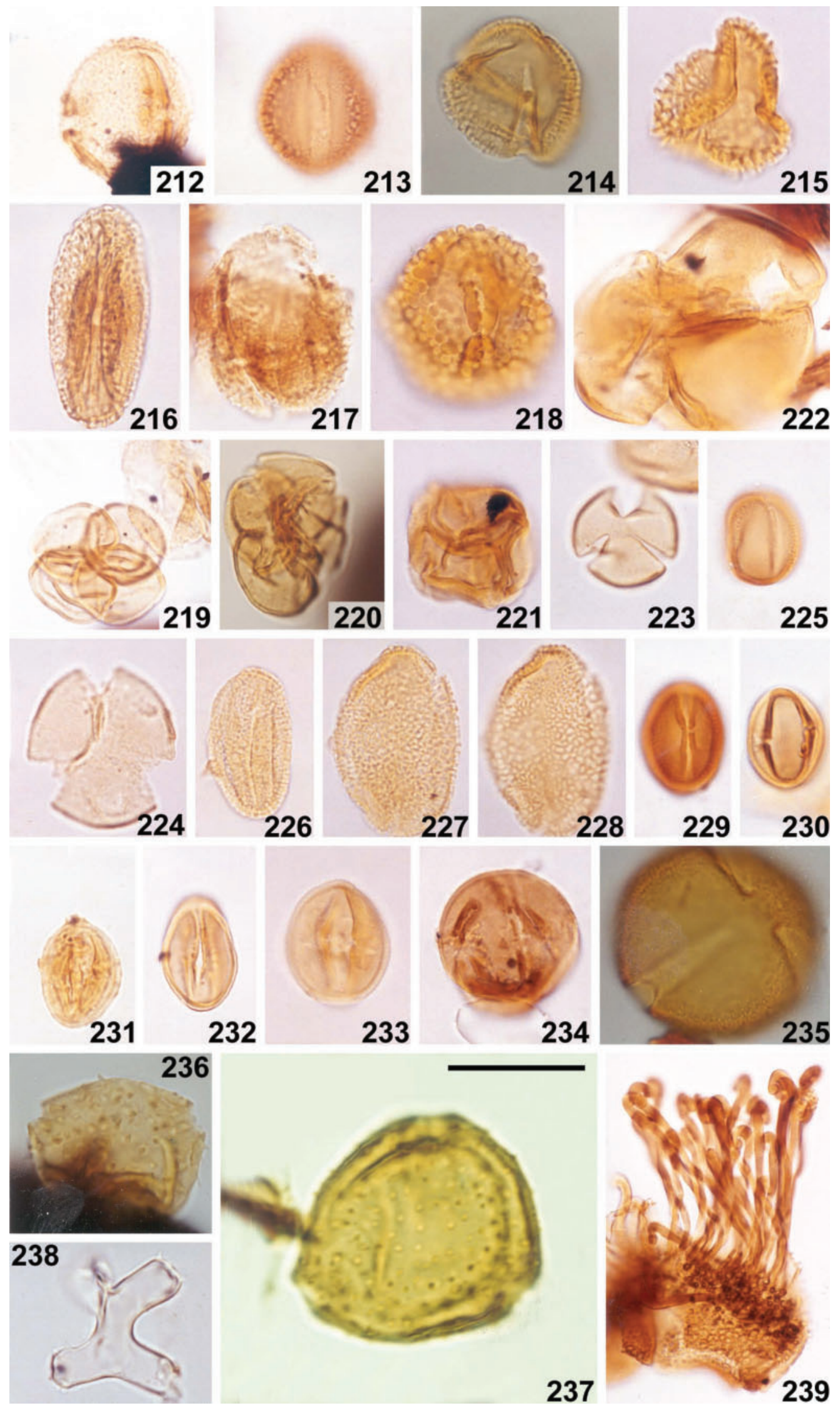


del Valle et al. 1997; Francis and Poole 2002). During this 200-million-year period, Araucariaceae and Podocarpaceae are likely to have formed the gymnosperm canopy stratum, whereas ferns and fern allies, which had formed the subcanopy strata, were progressively replaced by angiosperms, especially Proteaceae and Nothofagus. For example, Askin (1992) concluded that the migration and diversification of angiosperms within the coniferous woodlands 'peaked' in West Antarctica during the Late Cretaceous (CampanianMaastrichtian). Late Cretaceous microfloras from Prydz Bay (Macphail and Truswell 2004a) indicate that the same trend occurred in East Antarctica. Accordingly, it seems likely that the expansion of diverse angiosperm-rich communities during the early Tertiary, and their replacement by tundra and then fell-field communities during the Late Tertiary, were broadly synchronous across the continent.

Other high middle- to high-latitude sites allow the phytogeographic records at Prydz Bay to be compared with developments on islands in the Indian, Southern and the south-western Atlantic Oceans. These sites are (age range and citation in parentheses) Kerguelen Plateau (Miocene, Cookson 1947), Heard Island (Miocene, Truswell et al. 2005), East Tasman Plateau (Early-Late Eocene, M. K. Macphail, unpubl. data), South Tasman Rise (Early-Late Eocene, Truswell 1997), Tasmania (Late Eocene to Pliocene, Macphail and Hill 1994; Macphail et al. 1994; Hill et al. 1999), South Island of New Zealand (Middle Eocene to Pliocene, Pocknall and Mildenhall 1984; Mildenhall and Pocknall 1989; Pole 2007), West Antarctic Peninsula (Late Cretaceous to Eocene, Askin et al. 1991) and Falkland Islands (Middle? Miocene-Early Pliocene, Macphail and Cantrill 2006). In most instances, the palynostratigraphic data come from sites that then were at substantially higher palaeolatitudes than at present. For example, important earliest? Early Oligocene tillite palynosequences from Lemonthyme Creek and Wilmot Dam in north-western Tasmania (Macphail et al. 1993; Macphail and Hill 1994) represent a cold-climate flora growing at about palaeolatitude $61^{\circ} \mathrm{S}$ (see Veevers et al. 1991). A significant number of fossil species and genera are common to most localities and these provide a way to track the movement of individual morphospecies around the high-middle to polar latitudes of the southern hemisphere during the Late Palaeogene and Early Neogene.

\section{The Late Eocene Prydz Bay vegetation: part of a retrogressive polar succession}

The use of fossil pollen and spores to reconstruct the Late Eocene vegetation at Prydz Bay will always be contentious because the individual assemblages are partial records of past floras only, with some indication of abundance. What is certain is that the assemblages recovered from Site 1166 represent a vegetation of considerable diversity, comprising $>80$ angiosperms, 20 gymnosperms and about 25 cryptogams if it is assumed that each pollen or spore morphotype represents at least one plant species. Some of these may have been recycled from older sediments, e.g. Ruffordiaspora, but this is less certain for rare angiosperms such as Forcipites and Gambierina, because these genera may have survived in Antarctica long after the clades became extinct in southern Australia as a result of the rapid warming at the Paleocene-Eocene boundary (cf. Macphail et al. 1994).

Relative-abundance and species-distribution data (Tables 1,2) show that pollen dominance is shared between Nothofagus ( $\sim 5$ morphotypes) and Podocarpaceae ( $\sim 6$ morphotypes), although Proteaceae ( 25 morphotypes) are by far the single most diverse group. Ferns and fern allies are the least common in terms of their relative abundance and diversity. For this reason, Macphail and Truswell (2004a) and Truswell and Macphail (2004) proposed that the Prydz Bay vegetation was a form of floristically impoverished gymnosperm-Nothofagus rainforest scrub, analogous to the low-height Nothofagus communities found near to and above the treeline in Tasmania and Patagonia. Supporting observations were the following: (1) except for Nothofagus, the diversity of angiosperms appeared to be very low, and (2) ferns and other cryptogams that are typical of present-day tall Nothofagus rainforest stands were rare. The analogy with Tasmania was heightened by the shared presence of one species (Periporopollenites hexaporus) in cool-cold climate Oligo-Miocene floras in Tasmania.

Figs 212-239. Fig. 212. Rhoipites sp. A; tricolporate pollen grain in equatorial view; $170.98 \mathrm{~m}$ below the modern sea floor (mbsf). Fig. 213. Rhoipites sp. B; tricolporoidate reticulate pollen grain in equatorial view; $142.5 \mathrm{mbsf}$. Fig. 214. Rhoipites sp. C; tricolporate reticulate pollen grain in oblique polar view; $148.36 \mathrm{mbsf}$. Fig. 215. Rhoipites sp. D; tricolporate reticulate pollen grain in oblique polar view; 142.5 mbsf. Figs 216, 217. Rhoipites sp. E. Fig. 216. Tricolporate reticulate pollen grain in equatorial view; $180.4 \mathrm{mbsf}$. Fig. 217. Grain in oblique equatorial view, showing lalongate endopores; 180.4 mbsf. Fig. 218. Tetracolporites verrucosus Stover \& Partridge 1973; tetracolporate pollen grain in equatorial view, showing pronounced verrucate ornamentation; $148.36 \mathrm{mbsf}$. Figs 219, 222. Triporotetradites spp.; tetradahedral pollen tetrads with pore-like apertures; small and large forms, $148.36 \mathrm{mbsf}$ and $156.99 \mathrm{mbsf}$, respectively. Figs 220, 221. Tetradopollenites spp.; small tetrahedral pollen tetrads with well defined colpi; $148.36 \mathrm{mbsf}$. Fig. 223. Tricolpites confessus Stover \& Partridge 1973; showing exine thinning sharply to colpal margins; 148.36 mbsf. Fig. 224. Tricolpites sp. A; strongly oblate form with gaping colpi and scabrate sculpture; $156.99 \mathrm{mbsf}$. Fig. 225. Tricolpites sp. B; prolate pollen grain with puncto-reticulate sculpture; 142.5 mbsf. Fig. 226. Tricolpites sp. C; strongly prolate form with delicate fine reticulate sculpture; 156.99 mbsf. Figs 227, 228. Tricolpites sp. D; shows labrynthine appearance of muri, diminishing in size towards colpi; 142.5 mbsf. Figs 229, 230. Tricolporites sp. A; microreticulate grain, showing strongly thickened colpal margins (costae) that diverge towards the poles; $142.5 \mathrm{mbsf}$. Figs 231-233. Tricolporites sp. B; prolate morphotype with thick tectate-microreticulate exine, with fine columellae and diamond-shaped (Fig. 233), strongly lalongate endopores; 156.9 mbsf and 170.98 mbsf, respectively. Fig. 234. Tricolporites sp. C; sphaeroidal pollen grain, showing microreticulate sculpture and strong thickening of the nexine along the colpi and below the slit-shaped endopores; 170.98 mbsf. Fig. 235. Tricolporites sp. D; large sphaeroidal form with fine reticulate sculpture and broad colpi with blunt apices near the poles; 156.99 mbsf. Figs 236, 237. cf. Cranwellipollis spiniferus (McIntyre) Martin \& Harris 1974; triporate pollen grains, characterised by scattered spinules; 156.99 mbsf. Fig. 238. Paucilobimorpha spinosus (Cookson) Partridge 1999; 142.5 mbsf. Fig. 239. Cuticle of an unidentified invertebrate, $\times 450 ; 180.4 \mathrm{mbsf}$. Scale bar $=25 \mu \mathrm{m}$. 
Re-evaluation of the Prydz Bay microfloras (the present paper) demonstrates that the range of sclerophyll shrubs, especially palynologically under-represented Proteaceae, and herbs, was underestimated and the diversity is not dissimilar to modern alpine heath in Tasmania (see Crowden 1999), even though several of the plant families that are common in the latter vegetation were very rare or absent, e.g. Epacridaceae and Asteraceae. A feature of modern alpine heath in Tasmania is the occurrence of dwarfed specimens of rainforest tree species that are commonly found below the timberline. Accordingly, we propose that the Prydz Bay vegetation is more likely to have been a mosaic of krumholtz rainforest trees, scleromorphic shrubs and wetland herbs, analogous in structure to 'taiga' found in the transition zone between the boreal conifer forests and tundra biomes in Scandinavia, Russia and northern North America. Unlike for the Arctic Metasequoia forests growing at a palaeolatitude of $\sim 79^{\circ} \mathrm{N}$ in the Middle Eocene (Jahren and Sternberg 2008), the dominant species at Prydz Bay are unlikely to have been deciduous (Royer et al. 2003), although they will have shared with Eocene Metasequoia the ability to compete effectively in winter-dark, high-humidity environments and, less certainly, on poorly drained acidic soils. Similarly, the Oligo-Miocene tundra communities inferred by Prebble et al. (2006) differ from modern analogues in being dominated by woody species, not herbs. If mineral soils covered more than half the pollen-source area, this 'tundra' would be equivalent to modern fell-field sensu Polunin (1960).

At present, the only direct evidence of the structure of the Antarctic vegetation during the middle to late Tertiary comes from sites of different age at opposite sides of the continent. These are (1) West Antarctica, where macrofossils demonstrate that the Eocene polar woodlands on Seymour Island included trees that were at least $14 \mathrm{~m}$ tall (Cantrill and Poole 2005) and that a vegetation dominated by large trees of Nothofagus and Podocarpus persisted from the Late Paleocene into the Middle Eocene, although with a drop in diversity (see Francis et al. 2008 and references therein), and (2) the Transantarctic Mountains where macrofossils demonstrate that by Mio-Pliocene time the vegetation had been reduced to isolated low shrubs and herbs (fell-field) in scree interstices (Ashworth and Cantrill 2004). Nevertheless, for ecophysiological reasons, it is reasonable to assume that the onset of cryogenic climates in East Antarctica during the Middle to Late Eocene will have forced structural changes that are commensurate in direction, although across a much longer period of time, with temperature-forced ecological developments observed during interglacial-glacial transitions of the Late Quaternary, e.g. decreasing biomass and forest cover. Accordingly, and despite marked differences in timescale, we propose that the Prydz Bay vegetation was part of a polar retrogressive succession in which the Late Eocene 'taiga' vegetation is analogous to the 'teleocratic phase' and the Oligo-Miocene 'tundra' vegetation is analogous to the 'cryocratic phase' of a Late Quaternary interglacial-glacial cycle (cf. Birks and Birks 2004).

\section{Regional differences within Antarctica}

The only reasonably well dated microfloras published from East Antarctica that are contemporaneous with the Prydz Bay assemblages are those reported from the glacial erratics at McMurdo Sound in the Ross Sea. Data on the composition of these were provided by Askin (2000), who also included a review of earlier investigations, such as those by Cranwell et al. (1960) and Cranwell (1969). At a family level, the assemblages are basically similar to those from Prydz Bay. For example, Askin (2000) reported that cryptogam spores are rare and poorly diversified, Podocarpaceae pollen are common, Nothofagus is diverse, with more than seven Nothofagidites morphospecies or species groups being present and Proteaceae, although not common, is represented by at least 13 species. Other angiosperm families likely to be represented at both sites include Caryophyllaceae, Epacridaceae, Euphorbiaceae Myrtaceae, Restionaceae, Sapindaceae (Tribe Cupanieae) as well as one extinct group within the Triprojectacites.

Differences that are discernable are minor, e.g. in the presence/absence of very rare morphospecies, and these may not be of great phytogeographic significance. For instance, pollen attributed to Casuarinaceae has repeatedly been reported from the Ross Sea, from the sequence in the CIROS-1 core (Mildenhall 1989) from an interval now dated as Middle Eocene, and as a possible recycled element in younger sequences, including the Cape Roberts drillholes (Truswell 1983; Askin 2000; Askin and Raine 2000; Prebble et al. 2006); however, it occurs only in two samples at Prydz Bay. Other families recorded in this region but not at Prydz Bay include Liliaceae/Agavaceae, Anacardiaceae (as Tricolporites cf. paenestriatus), Chenopodiaceae (as ?Caryophyllaceae) and Onagraceae. Families recorded at Prydz Bay but not in the Ross Sea area include Aquifoliaceae, Callitrichaceae, Escalloniaceae and the extinct clades represented by Periporopollenites hexaporus and Periporopollenites sp. A. Macro- and microfossils demonstrate a diverse flora consisting of mosses, Nothofagus, Gramineae, Cyperaceae, Hippiduridaceae, Ranunculaceae, and possibly Caryophyllaceae, Chenopodiaceae and Myrtaceae, survived on the Transantarctic Mountains $\sim 500 \mathrm{~km}$ from the South Pole into the Neogene time (Ashworth and Kuschel 2003; Ashworth and Cantrill 2004). Miospores from the Antarctic Peninsula represent floras growing at $\sim 65^{\circ} \mathrm{S}$, which, for this reason alone, are likely to have been more diverse than floras growing at Prydz Bay at $\sim 70^{\circ} \mathrm{S}$; a detailed discussion of macrofloral remains suggests that this may have been so (see Francis et al. 2008). On present indications, families growing on the Antarctic Peninsula but not at higher latitudes in Antarctica include ?Cochlospermaceae, ?Dilleniaceae, Gunneraceae, Lauraceae, ?Melastomaceae, Monimiaceae and Sterculiaceae.

\section{Plant migration}

The role of Antarctica as a migration route for important elements of southern hemisphere rainforests has been the subject of considerable speculation (see Dettmann 1989; 
Dettmann and Jarzen 1990; Hill and Scriven 1995). Much of the literature is concerned with Cretaceous centres of origin in the southern South America-West Antarctic Peninsula region and the subsequent migration routes for several taxa away from this region. For example, the remains of land mammals previously known only from the Paleocene of southern South America confirm that a landbridge connection existed with West Antarctica into the Middle Eocene time (Marenssi et al. 1994; Reguero et al. 2002). In contrast, some marine faunas from West Antarctica demonstrate biogeographic links across the Pacific Ocean with Australia and New Zealand during the Eocene (Aguirre-Urreta et al. 1995).

With the possible exception of New Zealand, which rifted away from eastern Australia during the Campanian, many of the plant species shared between Antarctica and Australia during the earlier Tertiary are likely to have been part of the shared Gondwanan inheritance. Conversely, the strategic position of Prydz Bay provides a way to assess the role of East Antarctica in contributing species to southern Australia and subantarctic islands in the Southern Ocean during the Eocene-Oligocene transition and, therefore potentially, the role played by altered reorganisation of ocean currents and global cooling in the dispersal process. Necessary conditions are that the miospores are distinctive, are known to appear in the region first during or since the Late Eocene, are in situ and that the host sediments can be accurately dated. Plant taxa meeting these criteria include (fossil species in parentheses) Lophosoria (Cyatheacidites annulatus), Asteraceae (Tubulifloridites spp.), ChenopodiaceaeAmaranthaceae (Chenopodipollis chenopodiaceoides), Droseraceae (Fischeripollis), Gunneraceae (Tricolpites reticulatus), Proteaceae (Granodiporites nebulosus), Onagraceae (Corsinipollis sp. cf. C. epilobioides), Stylidiaceae (Tricolpites stylidioides) and Periporopollenites hexaporus. To what extent these taxa typify dispersal routes taken by other clades with less-distinctive miospores or with markedly different vagilities is unknown. In this context, we note that documenting also the absence of particular taxa at well studied sites, where these taxa might reasonably be expected to occur, is as important as recording the presence of such taxa (see e.g. discussion on the distribution of Gunneraceae below).

\section{East Antarctica to Tasmania}

A comparison of the microflora from the Late Eocene at Prydz Bay and microfloras recovered from earliest? Early Oligocene glacial sediments at Lemonthyme Creek and Wilmot Dam (Macphail et al. 1993; Macphail and Hill 1994) indicates that at least two taxa dispersed from Antarctica northwards into Tasmania during the Eocene-Oligocene transition. These are Fischeripollis sp. A of Truswell and Macphail (2004), which represents an extinct Droseraceae clade whose closest NLR is the North American venus fly-trap (Dionea), and Periporopollenites hexaporus, an extinct taxon that also occurs in a cool-climate Early Miocene flora at high elevations on the Central Plateau of Tasmania (Macphail et al. 1991). Neither species is recorded in the Late Eocene deposits on the
South Tasman Rise, nor on the East Tasman Plateau (M. K. Macphail, unpubl. data). Hence, we conclude that the dispersal events were in some way facilitated by the rapidcooling event marking the Eocene-Oligocene boundary in the Southern Ocean. If correct, then a key factor in the successful establishment of Fischeripollis sp. A and Periporopollenites hexaporus in glaciated terrain in north-western Tasmania may have been their preadaptation to cold climates (cf. Heinson and Hope 2006).

\section{Southern Australia-Antarctica}

The only examples of plants that may have dispersed from Australia to Antarctica during the middle to late Tertiary are Chenopodiaceae-Amaranthaceae and Onagraceae. The distinctive periporate (Chenopodipollis chenopodiaceoides) and triporate (Corsinipollis sp. cf. C. epilobioides) pollen types produced by these families are found in the Middle-Late Eocene to earliest Oligocene sediments in south-eastern Australia (Truswell and Owen 1988; Macphail 1999; Partridge 1999) and in younger? Oligocene marine sediments in the Ross Sea (Mildenhall 1989; Raine and Askin 2001) and probable Late Miocene sediments on Heard Island (Truswell et al. 2005). Whether Onagraceae have dispersed from Antarctica or southern Australia westwards onto Heard Island, or via another route from South America (see below), is unclear because the family also is recorded in New Zealand in the Late Oligocene (Pocknall 1982).

\section{South America-southern Australia}

The same comparison indicates that the monotypic South American fern Lophosoria, absent from Prydz Bay, whose spores (Cyatheacidites annulatus) appear in Tasmania in the earliest? Early Oligocene, is unlikely to have dispersed from East Antarctica, especially since macrofossils preserved in western Tasmania confirm that the plant reaching Tasmania almost certainly was the same species (L. quadrapinnata) that is now found in cool, wet habitats in South America (see Hill et al. 2001). In the case of Lophosoria, it should be noted that Tertiary populations represent a second dispersal event, as spores akin to the fossil form occur in the Cretaceous in both Australia and New Zealand (Dettmann 1986; Vajda and Raine 2003).

Onagraceae (Corsinipollis) pollen are recorded in the Middle-Late Paleocene in north-western Argentina (Quattrocchio et al. 1997) and not until the Middle-Late Eocene in southern Queensland and the earliest Oligocene in south-eastern Australia (Foster 1982; Truswell and Owen 1988; Macphail 1999). Embothrium (Granodiporites nebulosus), Asteraceae, tribe Mutisieae (Mutisiapollis patersonii) are other examples of South American endemics that may have dispersed across the Pacific Ocean via a route that did not involve Antarctica (see Macphail and Hill 1994). However, the direction of migration remains uncertain because the earliest occurrences of the fossil pollen types in South America are younger than in Tasmania (cf. Barreda and Palamarczuk 2000). 


\section{Southern Australia?-Kerguelen Archipelago}

Whether Lophosoria survived or not in Antarctica during the Late Eocene is less clear because a closely related morphotype recorded in the Ross Sea is assigned to the Late Cretaceous species Cyatheacidites tectifera (see Truswell 1983). Nevertheless, it seems probable that Lophosoria may have dispersed westwards from southern Australia or Tasmania during the Neogene because Cyatheacidites annulatus occurs in the Middle? Miocene sediments on the Kerguelen Islands (see Cookson 1947). Surprisingly, C. annulatus is not recorded in the Late Miocene sediments on Heard Island in the Indian Ocean (Truswell et al. 2005), nor in the Mio-Pliocene deposits on the Falkland Islands in the south-western Atlantic Ocean (Macphail and Cantrill 2006), despite the morphospecies occurring in probable middle Eocene sediments on the South Orkney Plateau (Mohr 2001) and in the Oligocene marine sediments on the Falkland Plateau (Bratzeva 1983). The Subfamily Tubuliflorae of the Asteraceae is, potentially, a second example of westward trans-oceanic dispersal because its fossil pollen (Tubulifloridites spp.) first occurs in Argentina in the Oligocene (Barreda and Palamarczuk 2000), in New Zealand in the Late Oligocene (Pocknall and Mildenhall 1984) and in southern Australia during the Early Miocene (Partridge 1999). It is present on Heard Island during the Late Miocene (Truswell et al. 2005).

\section{Adaptive radiation}

Adaptive radiation leading to endemism at the species and probably genus levels is likely to be concealed by broad fossil-species definitions as well as by the typically conservative nature of pollen in geological time. Nevertheless, the combined pollen data from Prydz Bay and the Ross Sea region point to the Nothofagus subgenera represented by the Nothofagidites brachyspinulosus complex and N. lachlaniae complex being able to rapidly evolve ecotypes that were more tolerant of increasingly low air temperatures and short growing seasons than most angiosperm clades. Significantly, Late Eocene microfloras at ODP Sites 1171D and 1172A on the South Tasman Rise and East Tasman Plateau, respectively, are co-dominated by the same morphospecies complex (M. K. Macphail, unpubl. data). Other families that may display cold climate-forced adaptive radiation and extinction during the Eocene-Oligocene transition are the Stylidiaceae and Gunneraceae.

Fossil Stylidiaceae pollen are absent at Prydz Bay. Askin and Raine (2000) have compared a spinose tetraporate grain recovered from Miocene glacimarine sediments in Cape Roberts Drillhole CRP-2/2A to that of Stylidiaceae. At present, the earliest convincing records of this predominantly herbaceous family are pollen grains (Tricolpites stylidioides) recovered from the earliest Oligocene glacigene sediments in north-western Tasmania, where the parent plants were rare elements in the cold-climate flora (Macphail and Hill 1994). Whether the family evolved in, or dispersed to, Tasmania during the Eocene-Oligocene is unknown, although, as for Lophosoria, dispersal from or via Antarctica is not supported by the available evidence. However, it is significant that the nearest analogues of Oligocene $T$. stylidioides are pollen produced by the species-poor genera Forstera and Phyllachne, which are now confined to montane-subalpine habitats in Tasmania, New Zealand and subantarctic South America. Since the Oligocene, the Stylidiaceae have dispersed into warmer habitats in mainland Australia, where $>100$ species of Stylidium occur in south-western Western Australia, and also to tropical East-Asia and India as well as to cooler habitats in New Zealand and South America (see Morley and Toelken 1988). In south-eastern mainland Australia, the earliest known record of Stylidium pollen is from Early Oligocene, implying that diversification of this genus in south-western Western Australia could be associated with either Late Cenozoic cooling or aridification (cf. Kershaw et al. 1994; Macphail et al. 1994; Macphail 1997, 1999).

In Gunneraceae, fossil pollen (Tricolporites reticulatus Cookson ex Couper 1953) closely resembling that produced by the living species of Gunnera demonstrates that this monotypic family was widespread across middle- to highlatitude landmasses in the southern hemisphere (Jarzen and Dettmann 1989). In Antarctica, T. reticulatus has been reported only from the relatively low-latitude sites in the Antarctic Peninsula, both in the Late Cretaceous (Dettmann and Thomson 1987) and Early Tertiary (Askin 1997). It is is absent from higher-latitude sites, including Prydz Bay, and the Ross Sea area (Truswell 1983; Askin 2000), and appears to have been a rare element in the Oligocene and/or Miocene vegetation in southern Australia and on the Ninetyeast Ridge, Kerguelen and Heard Islands in the Indian Ocean (Cookson 1947; Kemp and Harris 1977; Macphail 1999; Truswell et al. 2005). Modern Gunnera is found in wet habitats throughout the southern hemisphere, from Tierra del Fuego to the tropics. Major centres of distribution occur in the Andean region of South and Central America and New Zealand, suggesting that adaptive radiation here has been facilitated by Neogene orogeny, whereas the presence of a few species in Hawaii and Malesia is evidence for successful dispersal across oceanic water barriers during the same period. In Antarctica, the apparent restriction of Gunnera to the lower-latitude sites of the Antarctic Peninsula may shed some light on whether observed patterns of distribution reflect vicariance or dispersal events (see Wanntorp and Wanntorp 2003).

\section{Community evolution at high to middle polar latitudes}

Changes in the community dominance during the Eocene-Oligocene transition period are equally difficult to compare for three reasons. (1) Many of the samples come from islands lacking older or younger fossil records. (2) Depositional environments vary from nearshore marine to a buried landslip deposit (cf. Neves effect, Traverse 1988). (3) Relatively few Middle-Late Eocene and no OligoMiocene samples have yielded statistically reliable numbers (>100-200 specimens) of fossil miospores. Nevertheless, a comparison of the microfloras of the Prydz Bay and Ross Sea area with those recorded on the West Antarctic Peninsula and now treeless subantarctic islands in the Indian and southwestern Atlantic Oceans does illustrate the diversity of plant associations or communities able to develop at high latitudes, despite late Tertiary global cooling. The same comparison 
provides hints of the processes shaping community evolution on islands formed de novo by the emergence of oceanic volcanoes.

For example, differences in the Oligo-Miocene vegetation between the Kerguelen Archipelago and Heard Island mirror those recorded between the Late Eocene and Oligo-Miocene in East Antarctica and almost certainly reflect the same forcing processes (Late Tertiary cooling). In the Kerguelen Archipelago (latitude $48-50^{\circ} \mathrm{S}$ ), tree trunks are present and the associated microfossil evidence also indicates the presence of coniferous woodland during the Oligocene-Middle? Miocene (see Cookson 1947; Conran 1997). Philippe et al. (1998) claimed that wood recovered from a moraine is evidence that a tree species of Cupressaceae survived into Quaternary time. Conversely, there is no evidence that tree-sized plants were present on Heard Island (latitude $53^{\circ} \mathrm{S}$ ) during the Late Miocene despite its proximity $(550 \mathrm{~km})$ to the Kerguelen Islands (see Truswell et al. 2005). Here, the inferred palaeovegetation consisted of two distinct communities - low open associations dominated by Asteraceae and Poaceae and a Dicksoniaceaedominated coastal? association analogous to 'fern-bush' found on some subantarctic islands and Tierra del Fuego. These cryptogam and herbaceous communities stand in distinct contrast to broadly correlative communities on the Falkland Islands (palaeolatitude $\sim 52^{\circ} \mathrm{S}$ ) where macrofossils demonstrate that a relatively tall gymnosperm-Nothofagus rainforest was present sometime during the Middle? Miocene to Early Pliocene (Macphail and Cantrill 2006).

Unlike for Iceland (Grimsson et al. 2007), explanations involving differences in the vagility or isolation from the major continents per se are unconvincing. For example, fossil data from the Ninetyeast Ridge (Kemp and Harris 1975, 1977) confirm that woody and herbaceous species with temperate, subtropical and tropical NLRs, including some genera with intrinsically low vagility, were able to disperse over wide ocean gaps onto remote emergent islands in the Indian Ocean during the Palaeogene. These include (1) temperate rainforest trees such as Araucaria (Araucariacites australis), Microcachrys (Microcachryidites antarcticus), Phyllocladus (Microalatidites palaeogenicus) and possibly two subgenera of Nothofagus (Nothofagidites emarcidus-heterus and N. brachyspinulosus, although pollen of these taxa is likely to have been windblown), (2) rainforest trees with warm-temperate to tropical NLRs such as Anacardiaceae (cited as Nyssapollenites), Ascarina-Hedyosmum (Clavatipollenites sp. cf. C. hughesii), Didymeleaceae (Schizocolpus marlinensis), Myrtaceae (Myrtaceidites oceanicus), Sapotaceae (Sapotaceoidaepollenites rotundus) and (3) palms (Arecipites), mistletoes (Gothanipollis) and mangroves such as Avicennia (Rhoipites isoreticulatus) and Nypa (Spinizonocolpites prominatus). The presence of mangroves on Ninetyeast Ridge makes it highly probable that ocean currents as well as wind and birds were involved in the trans-oceanic dispersal of plants onto remote islands at high latitudes in the southern hemisphere.

Why trees became established in the Kerguelen and Falkland Archipelagos but apparently failed to reach or colonise Heard Island is difficult to explain. One possibility is that the direction of prevailing wind and ocean currents in the Southern Ocean changed substantially during the Middle
Miocene climatic transition (Flower and Kennett 1994; Lawver and Gahagan 2003). Ecologically plausible although equally difficult to test with the available data, is the hypothesis that the protected gully and? coastal niches, which would normally support tree species, had already been 'captured' by dense fern communities.

The palynostratigraphic data from Prydz Bay are thus useful in testing propositions underpinning conceptual models in oceanic biogeography. These include (1) the assertion that dispersal over oceanic water barriers by terrestrial organisms is common across 'geologic time' (Heaney 2007) and (2) the hypothesis that similar habitats make a new landmass receptive to colonisation by organisms from like habitats (Heinson and Hope 2006). For example, examination of Oligo-Miocene records of Cyatheacidites annulatus suggests that global cooling during the Eocene-Oligocene transition allowed the (present-day) endemic South American fern Lophosoria to reach southern Australia by the earliest Oligocene via direct, i.e. over water, dispersal rather than 'island-hopping' across Antarctica and the South Tasman Rise, and that this fern subsequently dispersed westwards from Australia onto the Kerguelen Islands during the Miocene. The apparent preferential westward direction of dispersal supports the 'west wind drift' model tested by Sanmartín et al. (2007). At the same time, the development of cool-cold climate niches allowed not only Lophosoria but also extinct cold-climate clades within the Droseraceae and the unidentified family represented by Periporopollenites hexaporus to colonise Tasmania. A comparison of fossil pollen records from Prydz Bay, subantarctic islands in the Indian and Atlantic Ocean, and adjacent continents may assist in dating nodes in the phylogenetic trees of angiosperm families and genera characterised by morphologically distinctive pollen, e.g. Droseraceae, Onagraceae and Stylidiaceae.

\section{Palaeoclimates}

Plant growth in East Antarctica during the Late Eocene would have been influenced by astronomical as well meteorological variables, including several months of winter darkness and mean annual and seasonal distribution of precipitation, and mean and extreme air temperatures during the major growth period in summer (see Macphail and Truswell 2004a). Nevertheless, as pointed out by Creber and Chaloner (1985), the light energy available at the ground level within very opencanopied vegetation types growing at high latitudes does not differ significantly from that received in temperate regions, and low photoperiods would not have constituted a barrier to plant growth, assuming precipitation and temperatures were not limiting.

The fossil record of plant and animal life demonstrates that this has been the case since the Early Mesozoic into the middle Tertiary, despite the location of Antarctica at polar latitudes since the Palaeozoic. Petrified Jurassic tree trunks preserved in growth position on the West Antarctic Peninsula are one example of relatively warm conditions near polar latitudes (del Valle et al. 1997); well preserved macrofossil remains from Seymour Island (Francis et al. 2008, and references therein) document Cretaceous and early Tertiary forests 
growing under similar warm climates; fossil wood at McMurdo Sound (Francis 2000) demonstrates the southerly extent of forest growth. The remains of warm-water nautiloids and a basking shark in Eocene sediments on the West Antarctic Peninsula are other examples of high-latitude warmth (Cione and Reguero 1998; Francis 2000; Dzik and Gazdzicki 2001). Similarly, modelling experiments and other proxy climatic data such as changes in leaf stomata density and the $\mathrm{pH}$ of sea surface water (see McElwain 1998; Pearson and Palmer 2000) indicate that $\mathrm{\rho CO}_{2}$ levels during the Middle and Late Eocene were considerably higher than the modern preindustrial levels.

In contrast, the palaeobotanical, isotopic and sedimentological evidence point to rapid cooling during the Eocene-Oligocene transition, with critical meteorological thresholds for the survival of arborescent communities being crossed sometime during this interval (Billups 2001; Zachos et al. 2001; Ivany et al. 2006; the present paper). What the 'threshold' values were is less clear, although Macphail and Truswell (2004a) drew attention to the high rainfall requirements of the NLRs of the woody taxa identified in the fossil record and suggested year-round high humidity, with an annual rainfall in the range 1200-2500 mm year $^{-1}$. Palaeotemperatures are more difficult to estimate because fossil pollen do not provide direct evidence of vegetation per se and the genera represented could have ranged from small shrubs to small to tall trees, depending on local conditions. Nevertheless, characterising growth as occurring under humid microthermal conditions implicitly implies mean annual air temperatures of $<12^{\circ} \mathrm{C}$ (see Nix 1982).

Several authors have attempted to infer more precise quantitative estimates of Palaeogene temperatures in other parts of Antarctica on the basis of plant macrofossil and microfossil data. For example, Thorn and DeConto (2006) summarised the available estimates, as the basis for testing the sensitivity of climate models to vegetation data. Francis (2000) referred to Eocene fragmentary wood remains from McMurdo Sound erratics and suggested cool-temperate climates, equivalent to the microthermal climates of Wolfe and Upchurch (1987), with mean annual temperatures $<13^{\circ} \mathrm{C}$ and cold winter conditions. These values are ecologically consistent with the Prydz Bay evidence. More recently, Francis et al. (2008) provided estimates of temperature and rainfall for Palaeogene floras fom Seymour Island on the basis of leaf-margin data. On this basis, Middle Eocene floras, which were dominated by Nothfagus, and which included rarer subtropical and warm-temperate taxa, thrived under strongly seasonal conditions, with mean annual temperatures $\sim 10^{\circ} \mathrm{C}$, and a rainfall in the vicinity of $1500 \mathrm{~mm}$. Mean temperatures for the warmest month of $\sim 24^{\circ} \mathrm{C}$ were suggested, with temperatures below freezing for the coolest month.

Data from pollen analysis rely only on what is known of temperature and rainfall conditions for NLRs, and cannot claim such precision; however, estimates from the Prydz Bay assemblages are in general accord with values from the the West Antarctic floras. Note also that Early Oligocene temperature estimates based on the comparison of Cape Roberts microfloras with the modern Patagonian vegetation indicate mean summer temperatures with a range of $10-12^{\circ} \mathrm{C}$ (Prebble et al. 2006). However, marked differences in latitudes and in latitudinal temperature gradients between the Palaeogene and the present day would seem to render such comparisons hazardous.

An alternative approach is to use sea surface temperatures to estimate air temperatures in coastal regions, once these data become available, although we note that woody species can be eliminated by short-term extreme events such as out-of-season ice storms or severe frosts as well as by longer-term trends such as summer air temperatures falling below a minimum value. In this context, the sedimentary sequence at Prydz Bay provides unequivocal evidence for progressive cooling, or at least, progressive development of regional ice during the middle to Late Eocene. For example, the massive sands of lithological Unit III include grains with surface textures indicative of glacial action and have been interpreted as reflecting montane glaciation to the south (Strand et al. 2003). Dropstones in the overlying Unit II represent ice extending onto the coast and support Billups' (2001) conclusions regarding the development of small, ephemeral ice-sheets in the Late Eocene. A corollary is that vegetation growing around the margins of Prydz Bay about the same time will have been subjected to cold, perhaps freezing, conditions during winter; however, again no quantitative temperature estimates are possible.

The causes of the rapid cooling and the development of a major ice cap on Antarctica close to the Eocene-Oligocene boundary remain controversial. Until recently, subsidence of the South Tasman Rise to bathyal depths during the Eocene-Oligocene transition was seen as the crucial event leading to the development of the Antarctic circumpolar current (ACC), and therefore to the thermal isolation and icesheet formation on the continent (Exon et al. 2004). Equally critical, however, to the ACC reaching its present-day status as the strongest known ocean current was the opening of Drake Passage between South America and the West Antarctic Peninsula. The estimated time of this 'event' ranges from $\sim 32$ million years ago (Early Eocene) to 17-23 million years ago (Early Miocene; see Lawver and Gahagan 2003; Barker and Thomas 2004). More recently, Lyle et al. (2007) proposed that cores of Late Oligocene to Holocene pelagic sediments from the South Pacific delimit the formation of the ACC to the Late Oligocene ( 23-25 million years ago), i.e. after the advent of ice-sheet formation on Antarctica, and concluded that the development of strong circumpolar currents may have been an effect of, rather than a trigger for, the cooling. Nonetheless, evidence continues to accumulate in support of ice-cap formation in West as well as East Antarctica during the earliest? Oligocene (Ivany et al. 2006; Sorlien et al. 2007).

We accept that vigorous deep-water circulation around Antarctica may not have developed as early as proposed by Exon et al. (2004), and that glacier development may have been facilitated by the terrain inland of the Ross Sea and Prydz Bay being higher than proposed by Stern et al. (2005) and Sorlien et al. (2007), or that regional cooling was due to other factors such as lowered $\mathrm{\rho CO}_{2}$ and orbital modulation (see Pagani et al. 2005). The links between decreasing atmospheric $\mathrm{CO}_{2}$ concentrations and the appearance of large ice sheets on Antarctica has been 
further demonstrated by Tripati et al. (2005). What does seem beyond dispute from the palaeobotanical evidence is that rapid cooling in the late Tertiary forced the collapse first of a conifer-fern 'Ice Forest' biome that had covered Antarctica since the Late Jurassic, then its taiga-like rainforest successor and, ultimately, the extinction of all woody species from the continent.

\section{Conclusions}

ODP Site 1166A is likely to remain a key site for understanding the botanical history of East Antarctica for both negative and positive reasons. The former is centred on the lack of alternative sites that are known to preserve an in situ flora for the climatically critical Late Eocene period (cf. ODP Sites 740, 741, Truswell 1991); the latter is centred on the high diversity of plant microfossils that can be assigned to extant taxa or extinct taxa with well constrained distributions elsewhere. We record here some 80 angiosperms, 20 gymnosperms and about 25 cryptogams, which suggests a vegetation of some diversity. We cannot, however, preclude the likelihood that several of these morphotaxa are reworked from older deposits. Some, including some of the fern spores, are known from the Mesozoic, whereas a recycled origin is less clear for some angiosperms, which may have persisted in Antarctica after the lineages became extinct in Australia.

The sedimentary record at Site 1166 shows that the sequence spans the transition from preglacial to glacial conditions. Preliminary studies at the site (Macphail and Truswell 2004a; Truswell and Macphail 2004) suggested to us that the Late Eocene vegetation at Prydz Bay may have been an impoverished gymnosperm-Nothofagus rainforest scrub. The present study re-evaluates this conclusion, noting the presence of a wider range of sclerophyll shrubs, especially Proteaceae and herbs. In this context, there is some similarity to modern alpine heath in Tasmania, which contains dwarfed rainforest trees. It is thus suggested that the Prydz Bay vegetation may have been a mosaic of krumholtz rainforest trees, scleromorphic shrubs and wetland herbs. Such is considered analogous to the 'taiga' of the transition zone between boreal conifer forests and tundra at high-latitude northern hemisphere sites. Interpretation of the climatic regime that supported such a vegetation is based on comparisons with the climates that support the nearest living relatives of the taxa identified, and is therefore tentative. However, it seems clear that it existed under a high-rainfall regime, in the range 1200-2500 mm year ${ }^{-1}$. Palaeotemperatures are more difficult to estimate, although the microthermal regime represented implies mean annual air temperatures of less than $12^{\circ} \mathrm{C}$. Such is in general accord with palaeotemperature estimates from other regions of Antarctica in the Eocene.

Many of the plant taxa shared between Australia and Antarctica during the Early Tertiary are likely to have been part of a Gondwana inheritance. The dominant Nothofagus, Podocarpaceae and Proteaceae are witness to this. Among less common taxa, the Prydz Bay sequence provides data illuminating the migration of species among southern Australia, the subantarctic Islands and Antarctica. For instance, a species within Droseraceae (Fischeripollis sp. A) appears in the Eocene of Antarctica before it does in Tasmania, as does the parent plant of the pollen Periporopollenites hexaporus. A possible preadaptation to cold may have facilitated this. Taxa within Chenopodiacaeae may have followed a reverse path, appearing later in Antarctica (on the basis of data from the Ross Sea and Heard Island) than they did in Australia. The absence at Prydz Bay of taxa common in Australia and in the subantarctic islands, such as the fern Lophosoria and the herbaceous angiosperm Gunnera, also raise questions about distribution patterns in high southern latitudes, and suggest a mixture of vicariance and long-distance dispersal may account for observed patterns. The distribution of particular taxa, and the development of a range of plant communities in this region, no doubt reflects variation in the vagility of individual elements of the flora, and changes in wind and ocean currents during Tertiary climatic evolution in the southern hemisphere.

\section{Acknowledgements}

We are grateful for the support of Geoscience Australia, in particular Dr Philip O'Brien (Co-chief Scientist on the ODP Leg 188) for providing samples, funding the palynogical analysis and publication of colour plates, and for much discussion regarding the geology of the Prydz Bay region. E. M. Truswell is grateful for the support provided by the Research School of Earth Sciences at the Australian National University, particularly that of Dr Patrick De Deckker, during her tenure as a Visiting Fellow. We express our thanks to Professor Geoff Hope (Department of Archaeology and Natural History, ANU) and Drs Dallas Mildenhall and Ian Raine (Geological and Nuclear Sciences, New Zealand) for helpful discussion on Tertiary Antarctica and related matters during many years. Additionally, Dr Christine Cargill (Australian National Botanical Gardens, Canberra) enabled our access to spores from cryptogams held in the ANBG collection.

\section{References}

Aguirre-Urreta MB, Marenssi S, Santillana S (1995) A new Eocene crab (Crustacea, decapoda) from Seymour Island, Antarctica. Antarctic Science 7, 277-281. doi: 10.1017/S0954102095000381

Ashworth AC, Cantrill DJ (2004) Neogene vegetation of the Meyer Desert Formation (Sirius Group) Transantarctic Mountains, Antarctica. Palaeogeography, Palaeoclimatology, Palaeoecology 213, 65-82.

Ashworth AC, Kuschel G (2003) Fossil weevils (Coleoptera: Curculionidae) from latitude 85 degrees $\mathrm{S}$ in Antarctica. Palaeogeography, Palaeoclimatology, Palaeoecology 191, 191-202. doi: 10.1016/S0031-0182(02)00712-5

Ashworth AC, Thompson FC (2003) Palaeontology: a fly in the biogeographic ointment. Nature 423, 135-136. doi: 10.1038/423135a

Askin RA (1988) Campanian to Paleocene palynological succession of Seymour and adjacent islands, northeastern Antarctic Peninsula. Geological Society of America Memoir 169, 131-153.

Askin RA (1989) Endemism and heterochroneity in the Late Cretaceous (Campanian) to Paleocene palynofloras of Seymour Island, Antarctica: implications for origins, dispersal and palaeoclimates of southern floras. Geological Society of London. Special Publication 47, 107-119. doi: 10.1144/GSL.SP.1989.047.01.09

Askin RA (1990a) Campanian to Paleocene spore and pollen assemblages of Seymour Island, Antarctica. Review of Palaeobotany and Palynology 65, 105-113. doi: 10.1016/0034-6667(90)90061-M

Askin RA (1990b) Cryptogam spores from the upper Campanian and Maastrichtian of Seymour Island, Antarctica. Micropaleontology 36, 141-156. doi: 10.2307/1485498 
Askin RA (1992) Late Cretaceous-Early Tertiary Antarctic outcrop evidence for past vegetation and climates. Americal Geophysical Union Antarctic Research Series 56, 61-73.

Askin RA (1997) Eocene-?earliest Oligocene terrestrial palynology of Seymour Island, Antarctica. In 'The Antarctic region: geological evolution and processes'. (Ed. CA Ricci) pp. 993-996. (Terra Antarctica Publication: Siena, Italy)

Askin RA (2000) Spores and pollen from the McMurdo Sound erratics, Antarctica. Americal Geophysical Union Antarctic Research Series 76, 161-181.

Askin RA, Baldoni AM (1998) The Santonian through Palaeogene record of Proteaceae in the southern South America-Antarctic Peninsula region. Australian Systematic Botany 11, 373-390. doi: 10.1071/SB97018

Askin RA, Raine JI (2000) Oligocene and Early Miocene terrestrial palynology of the Cape Roberts Drillhole CRP-2/2A, Victoria Land Basin, Antarctica. Terra Antarctica 7, 493-501.

Askin RA, Elliot DH, Stillwell JD, Zinmeister WJ (1991) Stratigraphy and paleontology of Campanian and Eocene sediments, Cockburn Island, Antarctic Peninsula. Journal of South American Earth Sciences 4, 99-117. doi: 10.1016/0895-9811(91)90021-C

Baldoni AM (1992) Palinologia de la Formacion Santa Marta, Cretacico Superio de la Isla James Ross. 'Geologia de la Isla James Ross'. (Ed. CA Rinalti) pp. 359-374. (Institute Anartico, Argentina: Buenos Aires)

Baldoni AM, Barreda V (1986) Estudio palinologico de las Formaciones Lopez de Bertodano y Sobral, Isla Vicecomodoro Marambio, Antartida. Boletim IG-USP, Serie Cientifica. Universidade de Sao Paulo 17, 89-98.

Barker PF, Thomas E (2004) Origin, signature and palaeoclimatic influence of the Antarctic Circumpolar Current. Earth-Science Reviews 66, 143-162. doi: 10.1016/j.earscirev.2003.10.003

Barreda VD, Palamarczuk S (2000) Estudio palinestratigrafico del Oligoceno tardio-Mioceno en secciones de la costa Patagonica y plataforma continental Argentina. INSURGEO Series Correlacion Geologica 14, $103-138$.

Batten DJ, Grenfell HR (1996) Green and blue-green algae. 7D Botryococcus. In 'Palynology: principles and applications. Vol. 1'. (Eds JC Jansonius, DC McGregor) pp. 205-214. (AASP Foundation: Houston, TX)

Billups K (2001) Glacial evolution of Antarctica: evidence from the deep-sea record. In 'The geologic record of the Antarctic ice sheet fom drilling, coring and seismic studies'. (Eds F Florindo, AK Cooper) p. 21. International Antostrat Symposium, Ettore Majorana Foundation and Centre for Scientific Culture, Erice, Italy.

Birkenmajer K, Zastawniak E (1989) Late Cretaceous-early Tertiary floras of King George Island, West Antarctica: their stratigraphic distribution and palaeoclimatic significance. Geological Society Special Publication 47, 227-240. doi: 10.1144/GSL.SP.1989.047.01.17

Birks HJB, Birks HH (2004) The rise and fall of forests. Science 305, 484-485. doi: 10.1126/science. 1101357

Bratzeva GM (1983) Spores and pollen from Cenozoic sediments of the Falkland Plateau, Site 511, Deep Sea Drilling Project Leg 71. Initial Reports of the Deep Sea Drilling Project 71, 907-931. doi: 10.2973/dsdp.proc.71.133.1983

Burger D (1988) Early Cretaceous environments in the Eromanga Basin: palynological evidence from GSQ Wyandra-1 corehole. Memoir of the Association of Australasian Palaeontologists 5, 173-186.

Burger D (1990) Early Cretaceous angiosperms from Queensland. Review of Palaeobotany and Palynology 65, 153-163. doi: 10.1016/0034-6667(90)90066-R

Cantrill DJ, Poole I (2005) A new Eocene Araucaria from Seymour Island, Antarctica: evidence from growth form and bark morphology. Alcheringa 29, 341-350. doi: 10.1080/03115510508619310
Case JA (1988) Palaeogene floras from Seymour Island, Antarctic Peninsula. Geological Society of America Memoir 169, 523-530.

Cione AL, Reguero MA (1998) A middle Eocene basking shark (Lamniformes, Cetorhinidae) from Antarctica. Antarctic Science 10, $83-88$.

Conran JG (1997) Paracordyline kerguelensis, an Oligocene monocotyledon macrofossil from the Kerguelen Islands. Alcheringa 21, 129-140. doi: 10.1080/03115519708619180

Cookson IC (1947) Plant microfossils from the lignites of Kerguelen Archipelago. British, Australian and New Zealand Antarctic Research Expedition 1929-1933 Report Series A5, 127-142.

Cookson IC (1950) Fossil pollen grains of proteaceous type from Tertiary deposits in Australia. Australian Journal of Biological Sciences 3, $166-177$.

Cooper AK, O'Brien PE (2004) Leg 188 synthesis: transitions in the glacial history of the Prydz Bay region, East Antarctica, from ODP drilling. Proceedings of the Ocean Drilling Program, Scientific Results 188.

Couper RA (1953) Upper Mesozoic and Cainozoic spores and pollen grains from New Zealand. New Zealand Geological Survey Palaeontological Bulletin 22, 1-77.

Couper RA (1960) New Zealand Mesozoic and Cainozoic plant microfossils. New Zealand Geological Survey Palaeontological Bulletin 32, 1-87.

Cranwell LM (1969) Antarctic and circum-Antarctic palynological contributions. Antarctic Journal of the United States 4, 197-198.

Cranwell LM, Harrington HJ, Speden IG (1960) Lower Tertiary microfossils from McMurdo Sound, Antarctica. Nature 186, 700-702. doi: $10.1038 / 186700 \mathrm{a} 0$

Creber GT, Chaloner WG (1985) Tree growth in the Mesozoic and Early Tertiary and the reconstruction of palaeoclimates. Palaeogeography, Palaeoclimatology, Palaeoecology 52, 35-59. doi: 10.1016/0031-0182(85)90030-6

Crowden RK (1999) Alpine vegetation. Flora of Australia Supplementary Series 8, 333-356.

DeConto RM, Pollard D (2003) A coupled climate-ice sheet modelling approach to the early Cenozoic history of the Antarctic ice sheet. Palaeogeography, Palaeoclimatology, Palaeoecology 198, 39-52. doi: 10.1016/S0031-0182(03)00393-6

De Jersey NJ, Raine JI (1990) Triassic and earliest Jurassic miospores from the Murihiku Supergroup, New Zealand. New Zealand Geological Survey Palaeontological Bulletin 62, 1-164.

Del Fueyo GM, Archangelsky S (2005) A new araucarian pollen cone with in situ Cyclusphaera Elsik from the Aptian of Patagonia, Argentina. Cretaceous Research 26, 757-768. doi: 10.1016/j.cretres.2005.04.005

del Valle RA, Lirio JM, Lusky JC, Morelli JR, Nunez HJ (1997) Jurassic trends in ecology and evolutions at Jason Peninsula, Antarctica. Antarctic Science 9, 443-444.

Dettmann ME (1963) Upper Mesozoic microfloras from southeastern Australia. Proceedings of the Royal Society of Victoria 77, 1-148.

Dettmann ME (1986) Significance of the spore genus Cyatheacidites in tracing the origin and migration of Lophosoria (Filicopsida). Special Papers in Palaeontology 35, 63-94.

Dettmann ME (1989) Antarctica: Cretaceous cradle of austral temperate rainforests? Geological Society Special Publication 47, 89-105. doi: 10.1144/GSL.SP.1989.047.01.08

Dettmann ME (1994) Cretaceous: the microfossil record. In 'History of the Australian vegetation: Cretaceous to Recent'. (Ed. RS Hill) pp. 143-170. (Cambridge University Press: Cambridge, UK)

Dettmann ME, Clifford HT (1992) Phylogeny and biogeography of Ruffordia, Mohria and Anemia (Schizaeaceae) and Ceratopsis (Pteridaceae) evidence from in situ and dispersed spores. Alcheringa 16, 269-314. doi: $10.1080 / 03115519208619111$ 
Dettmann ME, Jarzen DM (1988) Angiosperm pollen from uppermost Cretaceous strata of southeastern Australia and the Antarctic Peninsula. Memoir of the Association of Australasian Palaeontologists 5, 217-237.

Dettmann ME, Jarzen DM (1990) The Antarctic/Australian rift valley: Late Cretaceous cradle of north-eastern Australian relicts. Review of Palaeobotany and Palynology 65, 131-144. doi: 10.1016/0034-6667(90)90064-P

Dettmann ME, Jarzen DM (1991) Pollen evidence for Late Cretaceous differentiation of Proteaceae in southern polar forests. Canadian Journal of Botany 69, 901-906. doi: 10.1139/b91-116

Dettmann ME, Jarzen DM (1996) Pollen of proteaceous type from latest Cretaceous sediments, southeastern Australia. Alcheringa 20, 103-160. doi: 10.1080/03115519608619193

Dettmann ME, Jarzen DM (1998) The early history of the Proteaceae in Australia: the pollen record. Australian Systematic Botany 11, 401-438. doi: $10.1071 /$ SB97022

Dettmann ME, Thomson MRA (1987) Cretaceous palynomorphs from the James Ross Island area, Antarctica - a pilot study. Bulletin - British Antarctic Survey 77, 13-59.

Dettmann ME, Pocknall DT, Romero EJ, Zamaloa MC (1990) Nothofagidites Erdtman ex Potonie, 1960; a catalogue of species with notes on the paleogeographic distribution of Nothofagus Bl. (southern beech). New Zealand Geological Survey Palaeontological Bulletin 60, 1-79.

Dudgeon MJ (1983) Eocene pollen of probable proteaceous affinity from the Yaamba Basin, central Queensland. Memoir of the Association of Australasian Palaeontologists 1, 339-362.

Dzik J, Gazdzicki A (2001) The Eocene expansion of nautiloids to high latitudes. Palaeogeography, Palaeoclimatology, Palaeoecology 172, 297-312. doi: 10.1016/S0031-0182(01)00304-2

Enright NJ (1995) Conifers of tropical Australia. In 'Ecology of the southern conifers'. (Eds NJ Enright, RS Hill) pp. 197-222. (Melbourne University Press: Melbourne)

Enright NJ, Hill RS (1995) 'Ecology of the southern conifers.' (Melbourne University Press: Melbourne)

Enright NJ, Hill RS, Veblen TT (1995) The southern conifers - an introduction. In 'Ecology of the southern conifers. (Eds NJ Enright, RS Hill) pp. 1-9. (Melbourne University Press: Melbourne)

Erdtman G (1952) 'Pollen morphology and plant taxonomy. Angiosperms.' (Almqvist and Wiksell: Stockholm)

Exon NF, Kennett JP, Malone MJ (2004) Leg 189 synthesis: Cretaceous-Holocene history of the Tasmanian Gateway. Proceedings ODP Scientific Results 189, 1-37.

Flower BP, Kennett JP (1994) The middle Miocene climatic transition: East Antarctic ice sheet development, deep ocean circulation and global carbon cycling. Palaeogeography, Palaeoclimatology, Palaeoecology 108, 537-555. doi: 10.1016/0031-0182(94)90251-8

Foster CB (1982) Illustrations of Early Tertiary (Eocene) plant microfossils from the Yaamba Basin, Queensland. Geological Survey of Queensland Publication 381, 1-32.

Foster CB, Balme BE, Helby RJ (1994) First record of Tethyan palynomorphs from the Late Triassic of East Antarctica. AGSO Journal of Australian Geology \& Geophysics 15, 239-246.

Francis JE (2000) Fossil wood from Eocene high latitude forests McMurdo Sound, Antarctica. American Geophysical Union. Antarctic Research Series 76, 253-260.

Francis JE, Hill RS (1996) Fossil plants from the Pliocene Sirius Group, Transantarctic Mountains: evidence for climate from growth rings and fossil leaves. Palaios 11, 389-396. doi: 10.2307/3515248

Francis JE, Poole I (2002) Cretaceous and early Tertiary climates of Antarctica: evidence from fossil wood. Palaeogeography, Palaeoclimatology, Palaeoecology 182, 47-64.

doi: 10.1016/S0031-0182(01)00452-7
Francis JE, Ashworth A, Cantrill DJ, Crame JA, Howe J, Stephens R, Tosolini AM, Thorn V (2008) 100 million years of Antarctic climate evolution; evidence from fossil plants. In 'Antarctica: a keystone in a changing world'. (Eds AK Cooper, P Barrett, H Stagg, B Storey, E Stump, W Wise and the 10th ISAES editorial team) pp. 19-28. Proceedings of the 10th international symposium on Antarctic earth sciences, Washington, DC. (The National Academies Press: Washington, DC)

Grimsson F, Denk T, Simmarson LA (2007) Middle Miocene floras of Iceland - the early colonization of an island? Review of Palaeobotany and Palynology 144, 181-219.

doi: 10.1016/j.revpalbo.2006.07.003

Hannah MJ (2006) The palynology of ODP site 1165, Prydz Bay, East Antarctica: a record of Miocene glacial advance and retreat. Palaeogeography, Palaeoclimatology, Palaeoecology 231, 120-133. doi: 10.1016/j.palaeo.2005.07.029

Heaney LR (2007) Is a new paradigm emerging for oceanic island biogeography? Journal of Biogeography 34, 753-757. doi: 10.1111/j.1365-2699.2007.01692.x

Heinson T, Hope GS (2006) The Torresian connections: zoogeography of New Guinea. In 'Evolution and biogeography of Australasian vertebrates'. (Eds JR Merrick, M Archer, GM Hickey, MSY Lee) pp. 71-94. (Australian Scientific Publishing: Sydney)

Hill RS (1989) Fossil leaf. New Zealand Department of Scientific and Industrial Research Bulletin 245, 143-144.

Hill RS (1991) Tertiary Nothofagus (Fagaceae) macrofossils from Tasmania and Antarctica and their bearing on the evolution of the genus. Botanical Journal of the Linnean Society 105, 73-112. doi: 10.1111/j.1095-8339.1991.tb00200.x

Hill RS (2001) Biogeography, evolution and palaeoecology of Nothofagus (Nothofagaceae): the contribution of the fossil record. Australian Journal of Botany 49, 321-332. doi: 10.1071/BT00026

Hill RS, Read J (1991) A revised infrageneric classification of Nothofagus (Fagaceae). Botanical Journal of the Linnean Society 105, 37-72. doi: 10.1111/j.1095-8339.1991.tb00199.x

Hill RS, Scriven LJ (1995) The angiosperm-dominated woody vegetation of Antarctica: a review. Review of Palaeobotany and Palynology 86, 175-198. doi: 10.1016/0034-6667(94)00149-E

Hill RS, Truswell EM (1993) Nothofagus fossils in the Sirius Group, Transantarctic Mountains: leaves and pollen and their climatic implications. Antarctic Research Series, American Geophysical Union 60, 67073 .

Hill RS, Harwood DM, Webb PN (1996) Nothofagus beardmorensis (Nothofagaceae), a new species based on fossil leaves from the Pliocene Sirius Group, Transantarctic Mountains, Antarctica. Review of Palaeobotany and Palynology 94, 11-24. doi: 10.1016/S0034-6667(96)00003-6

Hill RS, Macphail MK, Jordan GJ (1999) Tertiary history and origins of the flora and vegetation. Flora of Australia Supplementary Series 8 , $39-63$.

Hill RS, Macphail MK, Jordan GJ (2001) Macrofossils associated with the fossil fern spore Cyatheacidites annulatus and their significance for southern hemisphere biogeography. Review of Palaeobotany and Palynology 116, 195-202. doi: 10.1016/S0034-6667(01)00088-4

Ivany LC, Van Simaeys S, Domack EW, Samson SD (2006) Evidence for earliest Oligocene glaciation on the Antarctic Peninsula. Geology 34, 377-380. doi: 10.1130/G22383.1

Jahren AH, Sternberg LSL (2008) Annual patterns within tree rings of the Arctic middle Eocene (ca. $45 \mathrm{Ma}$ ): isotope signatures of precipitation, relative humidity, and deciduousness. Geology 36, 99-102. doi: $10.1130 /$ G23876A.1

Jarzen DM, Dettmann ME (1989) Taxonomic revision of Tricolpites reticulatus Cookson ex Couper, 1953 with notes on the biogeography of Gunnera L. Pollen et Spores 31, 97-112. 
Jarzen DM, Dettmann ME (1992) Structure and form of Austral Cretaceous Normapolles-like pollen. Geobios 25, 569-583. doi: 10.1016/0016-6995(92)80097-W

Jefferson TH (1982) Fossil forests from the Lower Cretaceous of Alexander Island, Antarctica. Palaeontology 25, 681-708.

Jordan GJ (1995) Extinct conifers and conifer diversity in the early Pleistocene of western Tasmania. Review of Palaeobotany and Palynology 84, 375-387. doi: 10.1016/0034-6667(94)00116-2

Jordan GJ, Macphail MK (2003) A Middle-Late Eocene inflorescence of Caryophyllaceae from Tasmania, Australia. American Journal of Botany 90, 761-768. doi: 10.3732/ajb.90.5.761

Kemp EM (1975) Palynology of Leg 28 drill sites, Deep Sea Drilling Project. Initial Reports of the Deep Sea Drilling Project 28, 599-623. doi: 10.2973/dsdp.proc.28.116.1975

Kemp EM, Harris WK (1975) The vegetation of Tertiary islands on the Ninetyeast Ridge, Indian Ocean. Nature 258, 303-307. doi: $10.1038 / 258303 \mathrm{a} 0$

Kemp EM, Harris WK (1977) The palynology of Early Tertiary sediments, Ninetyeast Ridge, Indian Ocean. Special Papers in Palaeontology 19, $1-70$.

Kershaw AP, Martin HA, McEwen Mason JRC (1994) The Neogene: a period of transition. In 'History of the Australian vegetation: Cretaceous to Recent'. (Ed. RS Hill) pp. 299-327. (Cambridge University Press: Cambridge, UK)

Kyle RA, Schopf JM (1982) Permian and Triassic palynology of the Victoria Group, Transantarctic Mountains. In 'Antarctic geoscience'. (Ed. C Craddock) pp. 649-659. (University of Wisconsin Press: Madison, WI)

Ladd PG (1977) Pollen morphology of some members of the Restionaceae and related families, with notes on the fossil record. Grana 16, 1-14.

Large MF, Braggins JE (1991) 'Spore atlas of New Zealand ferns and fern allies.' (DSIR Publishing: Wellington)

Lawver LA, Gahagan LM (2003) Evolution of Cenozoic seaways in the circum-Antarctic region. Palaeogeography, Palaeoclimatology, Palaeoecology 198, 11-37. doi: 10.1016/S0031-0182(03)00392-4

Levy RH, Harwood DM (2000) Tertiary marine palynomorphs from the McMurdo Sound erratics, Antarctica. American Geophysical Union Antarctic Research Series 76, 183-242.

Lyle M, Gibbs S, Moore TC, Rea DK (2007) Late Oligocene initiation of the Antarctic Circumpolar Current: evidence from the South Pacific. Geology 35, 691-694. doi: 10.1130/G23806A.1

Mabberley DJ (1997) 'The plant book: a portable dictionary of the higher plants.' 2nd edn. (Cambridge University Press: Cambridge, UK)

Macphail MK (1997) Late Neogene climates in Australia: fossil pollen and spore-based estimates in retrospect and prospect. Australian Journal of Botany 45, 425-464. doi: 10.1071/BT96052

Macphail MK (1999) Palynostratigraphy of the Murray Basin, inland Southeastern Australia. Palynology 23, 197-240.

Macphail MK, Cantrill DJ (2006) Age and implications of the Forest Bed, Falkland Islands, southwest Atlantic Ocean: evidence from fossil pollen and spores. Palaeogeography, Palaeoclimatology, Palaeoecology 240, 602-629. doi: 10.1016/j.palaeo.2006.03.010

Macphail MK, Hill RS (1994) K-Ar dated palynofloras in Tasmania 1: Early Oligocene Proteacidites tuberculatus Zone sediments, Wilmot Dam, northwestern Tasmania. Papers and Proceedings of the Royal Society of Tasmania 128, 1-15.

Macphail MK, Partridge AD (1991) Australopollis obscurus. Palynological and Palaeobotanical Association of Australasia Association Newsletter 21, 6-7.

Macphail MK, Truswell EM (1993) Palynostratigraphy of the Bookpurnong Beds and related late Miocene-Early Pliocene facies in the central-west Murray Basin, part 2: spores and pollen. AGSO Journal of Australian Geology \& Geophysics 14, 383-409.
Macphail MK, Truswell EM (2004a) Palynology of Site 1166, Prydz Bay, East Antarctica. Proceedings of the Ocean Drilling Program. Scientific Results 188, 1-29.

Macphail MK, Truswell EM (2004b) Palynology of Neogene slope and rise deposits from ODP Sites 1165 and 1167, East Antarctica. Proceedings of the Ocean Drilling Program. Scientific Results 188, $1-20$.

Macphail MK, Hill RS, Forsyth SM, Wells PM (1991) A late Oligoceneearly Miocene cool climate flora in Tasmania. Alcheringa 15, 87-106. doi: 10.1080/03115519108619011

Macphail MK, Colhoun EA, Kiernan K, Hannan D (1993) Glacial climates in the Antarctic region during the late Palaeogene: evidence from northwest Tasmania, Australia. Geology 21, 145-148. doi: 10.1130/0091-7613(1993)021<0145:GCITAR>2.3.CO;2

Macphail MK, Alley NF, Truswell EM, Sluiter IRK (1994) Early Tertiary vegetation: evidence from spores and pollen. In 'History of the Australian vegetation: Cretaceous to Recent'. (Ed. RS Hill)pp. 189-261. (Cambridge University Press: Cambridge, UK)

Macphail MK, Hill K, Partridge A, Truswell E, Foster C (1995) Australia: 'Wollemi Pine' - old pollen records for a newly discovered species of gymnosperm. Geology Today 11, 48-50.

McElwain JC (1998) Do fossil plants signal palaeoatmospheric $\mathrm{CO}_{2}$ concentration in the geological past? Philosophical Transactions of the Royal Society of London 353, 83-96. doi: 10.1098/rstb.1998.0193

Marenssi SA, Reguero MA, Santillana SN, Vizcaino SF (1994) Eocene land mammals from Seymour Island, Antarctica: palaeobiogeographical implications. Antarctic Science 6, 3-15. doi: $10.1017 / \mathrm{S} 0954102094000027$

Marshall NG, Partridge AD (1988) The Eocene acritarch Tritonites gen. nov. and the age of the Marlin Channel, Gippsland Basin. Memoir of the Association ofAustralasian Palaeontologists 5, 239-257.

Martin ARH (1982) Proteaceae and the early differentiation of the central Australian flora. In 'Evolution of the flora and fauna of arid Australia'. (Eds WR Barker, PJ Greenslade) pp. 77-83. (Peacock Publications: Adelaide)

Martin ARH (1995) Palaeogene proteaceous pollen and phylogeny. Alcheringa 19, 27-40. doi: 10.1080/03115519508619096

Martin HA (1974) The identification of some Tertiary pollen belonging to the Euphorbiaceae. Australian Journal of Botany 22, 271-291. doi: 10.1071/BT9740271

Martin HA (1977) The history of Ilex (Aquifoliaceae) with special reference to Australia. Australian Journal of Botany 25, 655-673. doi: 10.1071/BT9770655

Martin HA (1994) Australian Tertiary phytogeography: evidence from palynology. In 'History of the Australian vegetation: Cretaceous to Recent'. (Ed. RS Hill) pp. 104-142. (Cambridge University Press: Cambridge, UK)

Martin HA (2001) The family Convulvulaceae in the Tertiary of Australia: evidence from pollen. Australian Journal of Botany 49, 221-234. doi: 10.1071/BT00057

McIntyre DJ, Wilson GJ (1966) Preliminary palynology of some Antarctic Tertiary erratics. New Zealand Journal of Botany 4, 315-321.

Mildenhall DC (1989) Terrestrial palynology. New Zealand Department of Scientific and Industrial Research Bulletin 245, 11-24.

Mildenhall DC, Pocknall DT (1989) Miocene-Pleistocene spores and pollen from Central Otago, South Island, New Zealand. New Zealand Geological Survey Palaeontological Bulletin 59, 1-128.

Milne LA (1998) Tertiary palynology: Beaupreaidites and new Conospermeae (Proteoideae) affiliates. Australian Systematic Botany 11, 553-603. doi: 10.1071/SB97013

Mohr BAR (1990) Eocene and Oligocene sporomorphs and dinoflagellate cysts from Leg 113 drill sites, Weddell Sea, Antarctica. Proceedings of the Ocean Drilling Program. Scientific Results 113, 95-612. 
Mohr BAR (2001) The development of Antarctic fern floras during the Tertiary, and paleoclimatic and paleobiogeographic implications. Palaeontographica Abteilung B 259, 167-208.

Morley BD, Toelken HR (Eds) (1988) 'Flowering plants in Australia.' (Rigby Publishers: Adelaide)

Nichols DJ, Ott HL (2006) Neotypes for Paleocene species in the Momipites-Caryapollenites pollen lineage. Palynology 30, 33-41. doi: $10.2113 /$ gspalynol.30.1.33

Nix HA (1982) Environmental determinants of biogeography and evolution in Terra Australis. In 'Evolution of the flora and fauna of arid Australia'. (Eds WR Barker, PJ Greenslade) pp. 47-66. (Peacock Publications: Adelaide)

Norvick M, Burger D (1976) Stratigraphic palynology of the the Cenomanian of Bathurst Island, Northern Territory, Australia. Bulletin of the Bureau of Mineral Resources. Geology and Geophysics, Australia 151, 1-154.

O'Brien PE, Cooper AK, Richter C, Shipboard Scientific Party (2001) Proceedings of the Ocean Drilling Program, Initial Reports 188. CD-ROM. Available from the Ocean Drilling Program, Texas A \& M University, College Station, TX.

Ogden J, Stewart GH (1995) Community dynamics of the New Zealand conifers. In 'Ecology of the southern conifers'. (Eds NJ Enright, RS Hill) pp. 81-119. (Melbourne University Press: Melbourne)

Pagani M, Zachos JC, Freeman KH, Tripple B, Boharty S (2005) Marked decline in atmospheric carbon dioxide concentrations during the Palaeogene. Science 309, 600-603. doi: 10.1126/science.1110063

Partridge AD (1999) Late Cretaceous to Tertiary geological evolution of the Gippsland Basin, Victoria. PhD Thesis, Latrobe University, Melbourne.

Pearson PN, Palmer MR (2000) Atmospheric carbon dioxide concentrations over the past 60 million years. Nature 406, 695-699. doi: $10.1038 / 35021000$

Philippe M, Giret A, Jordan GJ (1998) Bois fossiles tertiaires et quaterniares de Kerguelen (Oćean Indien Austral). C.R. Académie des Sciences, Paris, Sciences de la Terre et des Planets 326, 901-906.

Pocknall DT (1982) Palynology of the late Oligocene Pomahaka Estuarine Bed sediments, Waikoikoi, Southland, New Zealand. New Zealand Journal of Botany 20, 263-287.

Pocknall DT, Mildenhall DC (1984) Late Oligocene-Early Miocene spores and pollen from Southland, New Zealand. New Zealand Geological Survey Palaeontological Bulletin 51, 1-66.

Pole M (2007) Conifer and cycad distribution in the Miocene of southern New Zealand. Australian Journal of Botany 55, 143-164. doi: 10.1071/BT06056

Pole M, Hill B, Harwood D (2000) Eocene plant macrofossils from erratics, McMurdo Sound, Antarctica. Americal Geophysical Union Antarctic Research Series 76, 243-251.

Polunin N (1960) 'Introduction to plant geography and some related sciences.' (Longmans: London)

Poole I, Mennega AMW, Cantrill DJ (2003) Valdivian ecosystems in the Late Cretaceous and early Tertiary of Antarctica: further evidence from myrtaceous and eucryphiaceous fossil wood. Review of Palaeobotany and Palynology 124, 9-27. doi: 10.1016/S0034-6667(02)00244-0

Prebble JG, Raine JI, Barrett PJ, Hannah MJ (2006) Vegetation and climate from two glacioeustatic sedimentary cycles ( 31 and $24 \mathrm{Ma}$ ) cored by the Cape Roberts Project, Victoria Land Basin, Antarctica. Palaeogeography, Palaeoclimatology, Palaeoecology 231, 41-57. doi: 10.1016/j.palaeo.2005.07.025

Quattrocchio M, Volkheimer W, del Papa C (1997) Palynology and palaeoenvironment of the 'Faja Gris' Mealla Formation (Salta group) at Garabatal Creek (NW Argentina). Palynology 21, 231-247.

Raine JI (1998) Terrestrial palynomorphs from Cape Roberts Project Drillhole CRP-1, Ross Sea, Antarctica. Terra Antarctica 5, 539-548.
Raine JI, Askin RA (2001) Terrestrial palynology of Cape Roberts Drillhole CRP-3, Victoria Land Basin, Antarctica. Terra Antarctica 8, 389-400.

Raine JI, Askin RA, Warny S, Mohr BAR, Hannah MJ (2008) An Early and Middle Miocene plant record from Victoria Land, Antarctica. In 'Terra Nostra. International palynological congress XII', Bonn, Germany, Abstracts, 230.

Read J (1999) Rainforest ecology. Flora of Australia Supplementary Series 8, 160-197.

Read J, Francis J (1992) Responses of some southern hemisphere tree species to a prolonged dark period and their implications for high latitude Cretaceous and Tertiary floras. Palaeogeography, Palaeoclimatology, Palaeoecology 99, 271-290. doi: 10.1016/0031-0182(92)90019-2

Reguero MA, Marenssi SA, Santillana SN (2002) Antarctic Peninsula and South American (Patagonia) Palaeogene terrestrial fauna and environments: biogeographic relationships. Palaeogeography, Palaeoclimatology, Palaeoecology 179, 189-210. doi: 10.1016/S0031-0182(01)00417-5

Romero EJ (1977) 'Polen de gimnospermas y fagaceas de la formacion Rio Turbio (Eoceno), Santa Cruz, Argentina.' (Unidad de Paleobotanica y Palinologia Centro de Investigaciones en Recursos Geologicos: Buenos Aires)

Royer DL, Osborne CP, Beerling DJ (2003) Carbon loss by deciduous trees in a $\mathrm{CO}_{2}$-rich ancient polar environment. Nature 424, 60-62. doi: 10.1038 /nature 01737

Sanmartín I, Wanntorp L, Winkworth RC (2007) West wind drift revisited: testing for directional dispersal in the southern hemisphere using eventbased tree fitting. Journal of Biogeography 34, 398-416. doi: 10.1111/j.1365-2699.2006.01655.x

Sajjadi F, Playford G (2002a) Systematic and stratigraphic palynology of Late Jurassic-earliest Cretaceous strata of the Eromanga basin, Queensland, Australia. Part one. Palaeontographica Abteilung B 261, $1-97$.

Sajjadi F, Playford G (2002b) Systematic and stratigraphic palynology of Late Jurassic-earliest Cretaceous strata of the Eromanga Basin, Queensland, Australia. Part two. Palaeontographica Abteilung B 261, 99-165.

Sorlien CC, Luyendyk BP, Wilson DS, Decesan RC, Bartek LR, Diebold JB (2007) Oligocene development of the West Antarctic Ice Sheet recorded in eastern Ross Sea strata. Geology 35, 467-470. doi: $10.1130 / \mathrm{G} 23387 \mathrm{~A} .1$

Stern TA, Baxter AK, Barrett PJ (2005) Isostatic rebound due to glacial erosion within the Transantarctic Mountains. Geology 33, 221-224. doi: $10.1130 / \mathrm{G} 21068.1$

Stover LE, Partridge AD (1973) Tertiary and Late Cretaceous spores and pollen from the Gippsland Basin, southeastern Australia. Proceedings of the Royal Society of Victoria 85, 237-286.

Strand K, Passchier S, Nasi J (2003) Implications of quartz grain microtexture for onset of Eocene/Oligocene glaciation in Prydz Bay, ODP Site 1166, Antarctica. Palaeogeography, Palaeoclimatology, Palaeoecology 198, 101-111. doi: 10.1016/S0031-0182(03)00396-1

Thorn VC, de Conto R (2006) Antarctic climate at the Eocene/Oligocene boundary - climate model sensitivity to high latitude vegetation type and comparisons with the palaeobotanical record. Palaeogeography, Palaeoclimatology, Palaeoecology 231, 134-157. doi: 10.1016/j.palaeo.2005.07.032

Traverse A (1988) 'Paleopalynology.' (Unwin Hyman: Boston, MA)

Tripati A, Backman J, Elderfield H, Ferretti P (2005) Eocene bipolar glaciation associated with global carbon cycle changes. Nature 436, 341-346. doi: 10.1038 /nature 03874

Truswell EM (1983) Recycled Cretaceous and Tertiary pollen and spores in Antarctic marine sediments: a catalogue. Palaeontographica Abteilung $B$ 186, 121-174. 
Truswell EM (1990) Antarctica: a terrestrial vegetation history. In 'The geology of Antarctica'. (Ed. RJ Tingey) pp. 499-528. (Oxford University Press: Oxford)

Truswell EM (1991) Data report: palynology of sediments from Leg 119 drillholes in Prydz Bay, East Antarctica. Proceedings of the Ocean Drilling Program. Scientific Results 119, 941-945.

Truswell EM (1997) Palynomorph assemblages from marine Eocene sediments on the west Tasmanian continental margin and the South Tasman Rise. Australian Journal of Earth Sciences 44, 633-654. doi: $10.1080 / 08120099708728342$

Truswell EM, Macphail MK (2004) Carnivorous plants at high latitudes: pollen evidence for Droseraceae growing in East Antarctica during the Late Eocene. Memoir of the Association of Australasian Palaeontologists 29, 85-97.

Truswell EM, Marchant NG (1986) Early Tertiary pollen of probable droseracean affinity from central Australia. Special Papers in Palaeontology 35, 163-178.

Truswell EM, Owen JA (1988) Eocene pollen from Bungonia, New South Wales. Association of Australasian Palaeontologists Memoir 5, 259-284.

Truswell EM, Sluiter IR, Harris WK (1985) Palynology of the Oligo-Miocene sequence in the Oakvale-1 corehole, western Murray Basin, South Australia. BMR Journal of Australian Geology and Geophysics 9, 267-295.

Truswell EM, Dettmann ME, O'Brien PE (1999) Mesozoic palynofloras from the Mac.Robertson Shelf, East Antarctica: geological and phytogeographic implications. Antarctic Science 11, 239-255. doi: 10.1017/S0954102099000309

Truswell EM, Quilty PG, McMinn A, Macphail MK, Wheller GE (2005) Late Miocene vegetation and palaeoenvironments of the Drygalski Formation, Heard island, Indian Ocean: evidence from palynology. Antarctic Science 17, 427-442. doi: 10.1017/S0954102005002865

Tulip JR, Taylor G, Truswell EM (1982) Palynology of Tertiary Lake Bunyan, Cooma, New South Wales. BMR Journal of Geology and Geophysics 7 , $255-268$.

Vajda V, Raine JI (2003) Pollen and spores in marine Cretaceous/ Tertiary boundary sediments at mid-Waipara River, North Canterbury, New Zealand. New Zealand Journal of Geology and Geophysics 46, 255-273.
Veevers JJ, Powell CMcA, Roots SR (1991) Review of seafloor spreading around Australia. 1. Synthesis of the patterns of spreading. Australian Journal of Earth Sciences 38, 373-389. doi: 10.1080/08120099108727979

Veblen TT, Burns BR, Kitzberger T, Lara A, Villalaba R (1995) The ecology of the conifers of southern South America. In 'Ecology of the southern conifers'. (Eds NJ Enright, RS Hill) pp. 120-155. (Melbourne University Press: Melbourne)

Veblen TT, Hill RS, Read J (1996) 'The ecology and biogeography of Nothofagus forests.' (Yale University Press: New Haven, CT)

Wanntorp L, Wanntorp HE (2003) The biogeography of Gunnera L.; vicariance and dispersal. Journal of Biogeography 30, 979-987.

Warny S, Wrenn JH, Bart PJ, Askin RA (2006) Palynology of the NBP0301A transect in the northern basin, western Ross Sea, Antarctica; a Late Pliocene record. Palynology 30, 151-182. doi: 10.2113/gspalynol.30.1.151

Whitehead JM, Quilty PG, McKelvey BC, O’Brien PE (2006) A review of the Cenozoic stratigraphy and glacial history of the Lambert Graben-Prydz Bay region, East Antarctica. Antarctic Science 18, 83-99. doi: $10.1017 /$ S0954102006000083

Wilson GJ (1967) Some new species of Lower Tertiary dinoflagellates from McMurdo Sound, Antarctica. New Zealand Journal of Botany 5, $57-83$.

Wolfe JA, Upchurch GR (1987) North American non-marine climates and vegetation during the Late Cretaceous. Palaeogeography, Palaeoclimatology, Palaeoecology 61, 33-77. doi: 10.1016/0031-0182(87)90040-X

Wrenn JH, Hart GF (1988) Palaeogene dinoflagellate cyst biostratigraphy of Seymour Island, Antarctica. Geological Society of America Memoir 169, 321-447.

Zachos J, Billups K, Pagani H, Sloan L, Thomas E (2001) Trends, rhythms, and aberrations in global climate 65 Ma to Present. Science 292, 686-693. doi: 10.1126/science. 1059412

Zamaloa MC (2004) Miocene algae and spores from Tierra del Fuego, Argentina. Alcheringa 28, 205-227. doi: 10.1080/03115510408619282

Manuscript received 27 October 2008, accepted 5 March 2009 